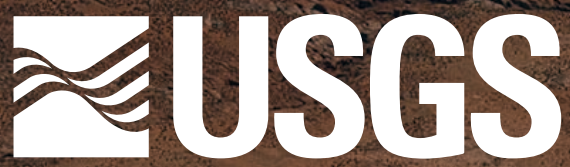

science for a changing world

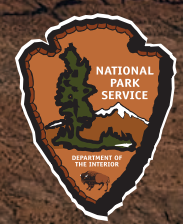

Prepared in cooperation with the National Park Service

\title{
The Structuire and Functioning of Dryland Ecosystems Conceptual Models to Inform Long-Term Ecological Monitoring
}
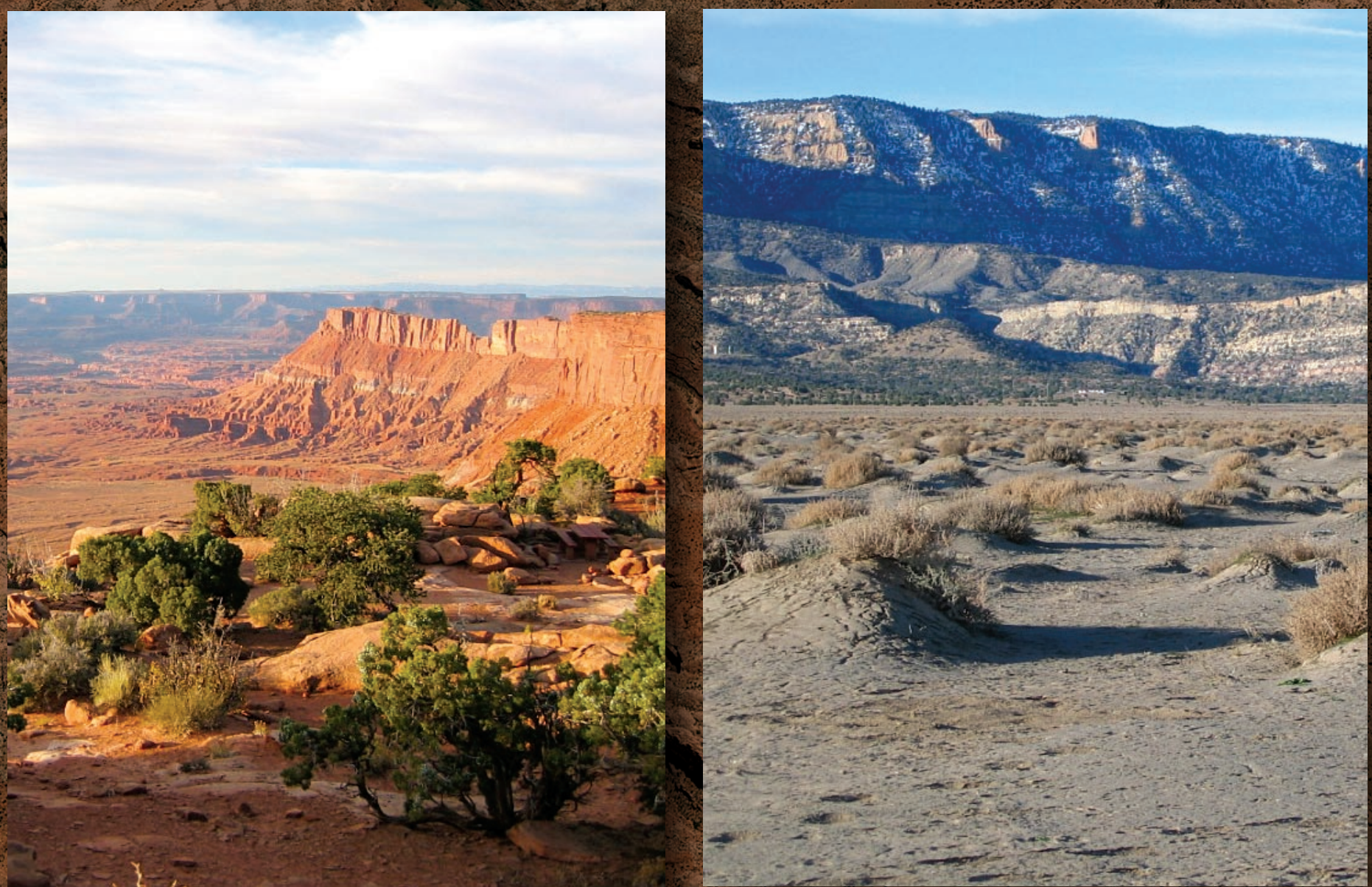

Scientific Investigations Report 2005-5197 


\section{The Structure and Functioning of Dryland Ecosystems-Conceptual Models to Inform Long-Term Ecological Monitoring}

By Mark E. Miller

Prepared in cooperation with the National Park Service

Scientific Investigations Report 2005-5197 


\section{U.S. Department of the Interior \\ Gale A. Norton, Secretary \\ U.S. Geological Survey \\ P. Patrick Leahy, Acting Director}

\section{U.S. Geological Survey, Reston, Virginia: 2005}

For product and ordering information:

World Wide Web: http://www.usgs.gov/pubprod

Telephone: 1-888-ASK-USGS

For more information on the USGS-the Federal source for science about the Earth, its natural and living resources, natural hazards, and the environment:

World Wide Web: http://www.usgs.gov

Telephone: 1-888-ASK-USGS

Any use of trade, product, or firm names is for descriptive purposes only and does not imply endorsement by the U.S. Government.

Although this report is in the public domain, permission must be secured from the individual copyright owners to reproduce any copyrighted materials contained within this report.

\section{Suggested citation:}

Miller, M.E., 2005, The Structure and Functioning of Dryland Ecosystems-Conceptual Models to Inform Long-Term Ecological Monitoring: U.S. Geological Survey Scientific Investigations Report 2005-5197, 73 p.

Keywords: arid ecosystems, conceptual model, degradation, disturbance, ecosystem dynamics, ecosystem management, ecosystem structure and function, indicators, monitoring, resilience, resistance, stressors. 


\section{Contents}

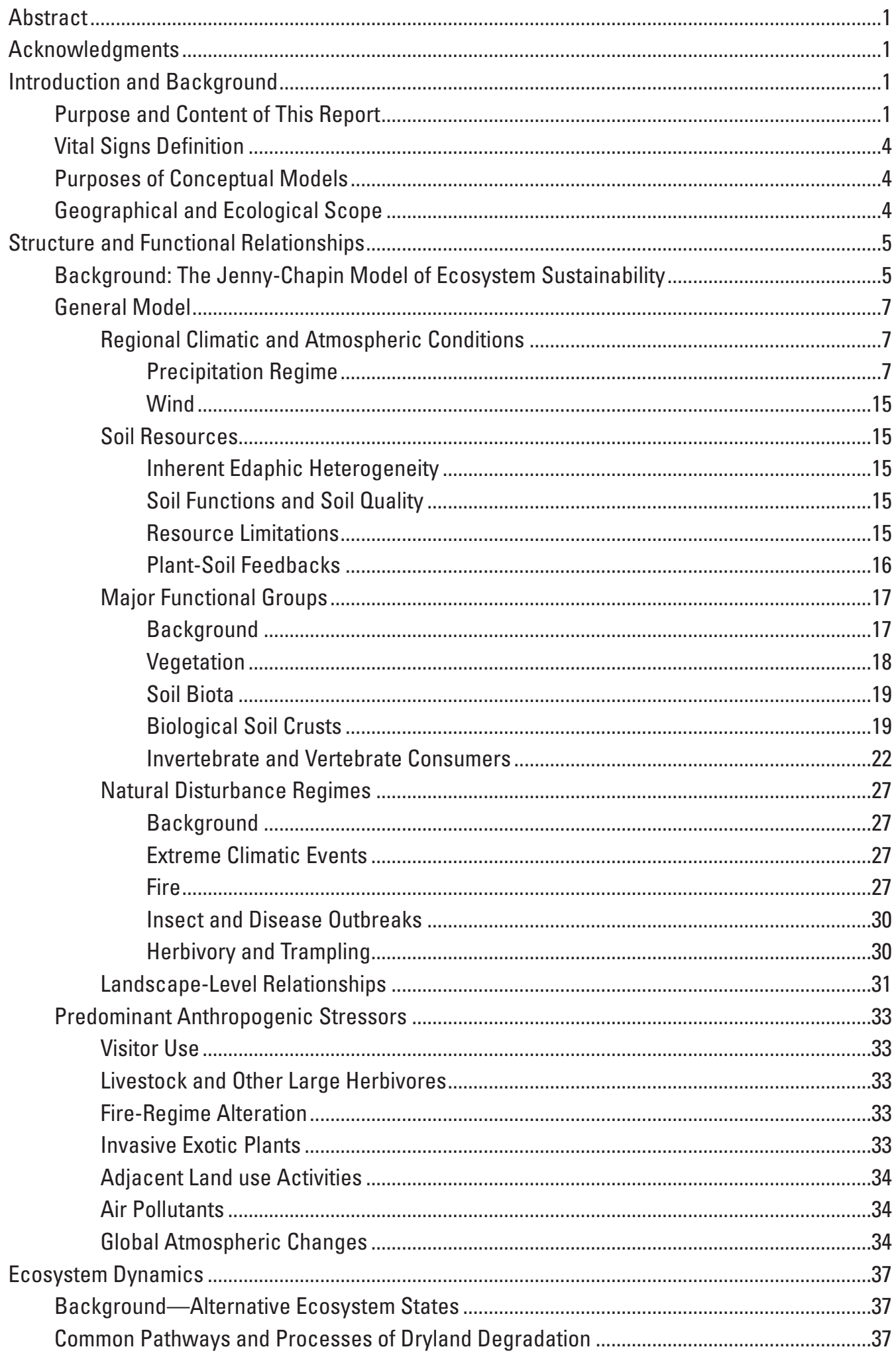


Transition 1-Exotic Plant Invasion.................................................................................39

Transition 2-Woody Plant Encroachment/Thickening ................................................40

Transition 3-Soil Erosion/Redistribution..................................................................42

Transition 4-Soil Erosion/Redistribution..................................................................45

Transition 5-Exotic Conversion ..............................................................................46

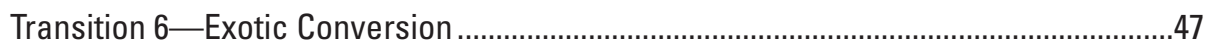

Transition 7-Soil Erosion/Redistribution ......................................................................

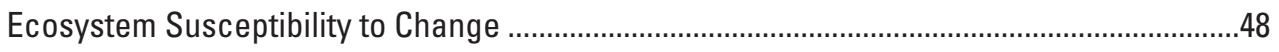

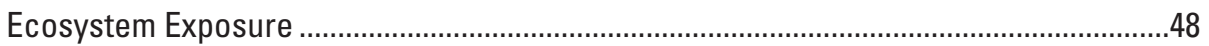

Ecosystem Resistance and Resilience ..........................................................................

Implications for Ecosystem Classification...................................................................49

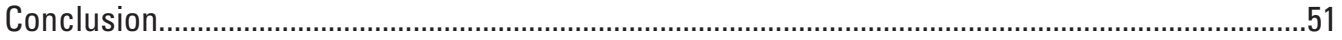

References

\section{Figures}

1. Map showing mean annual precipitation and mean seasonal precipitation for National Weather Service Cooperative Network stations located at or near NPS units of the Southern and Northern Colorado Plateau Networks ..............................

2. Map showing location of NCPN and SCPN parks in relation to ecoregions......................9

3. Modified version $(A)$ of the Jenny-Chapin model that serves as the general ecosystem model for the SCPN and NCPN

4. General conceptual model depicting the structure and functioning of dryland ecosystems

5. Distribution of precipitation events (based on daily values) by size class at the Needles District of Canyonlands National Park, 1965-1998.

6. Map depicting regional variations in the estimated maximum intensity of precipitation $(\mathrm{mm} / \mathrm{hr})$ that can be expected to occur over a 5-min period with 50 percent probability during any given year at NWS stations located at or near NCPN and SCPN units

7. Magnetic susceptibility (mean $\pm 1 \mathrm{SE}$ ) of surficial sediments at a formerly grazed grassland site in the Island in the Sky District of Canyonlands National Park, a currently grazed grassland site outside the Park, and of Navajo Sandstone bedrock.

8. Examples of landscape-level processes and attributes important for ecosystem monitoring

9. Conceptual model depicting major types of degraded alternative states.

10. Conceptual model illustrating the processes by which excessive grazing, fire suppression, and climate interactively can lead to increasing dominance by woody plants

11. Conceptual model illustrating the processes by which excessive grazing, soil-surface disturbances, off-site soil-surface disturbances, and climate interactively can lead to accelerated erosion/redistribution of soil resources by wind.

12. Conceptual model illustrating the processes by which excessive grazing, soil-surface disturbances, off-site hydrologic function, and climate interactively can lead to accelerated erosion/redistribution of soil resources by water 
13. Example of site where accelerated erosion has led to the significant loss of soil resources and persistent alteration of ecosystem structure and functioning....

14. Conceptual model illustrating the processes by which increasing woody-plant dominance, excessive grazing, soil-surface disturbances, off-site soil disturbances, and climate interactively can lead to accelerated erosion/redistribution of soil resources by wind.

15. Conceptual model illustrating the processes by which increasing woody-plant dominance, excessive grazing, soil-surface disturbances, off-site hydrologic function, and climate interactively can lead to accelerated erosion/redistribution of soil resources by water.

16. Conceptual model illustrating the processes by which excessive grazing, soil-surface disturbances, management-prescribed fire and mechanical thinning, wildfire, atmospheric nitrogen deposition, concentrated livestock activites, landscape-level soil-resource transfers, and climate interactively can lead to increasing dominance (and site conversion) by exotic annual grasses.

17. Conceptual model illustrating processes by which increasing woody-plant dominance, soil-surface disturbances, insect pests, climate, off-site fuel/fire conditions, wildfire, and management-prescribed fire interactively can lead to increasing dominance (and site conversion) by exotic annual grasses

18. Conceptual model illustrating processes by which increasing site dominance by exotic annual grasses, excessive grazing, soil-surface disturbances, off-site soil-surface disturbances, and climate interactively can lead to accelerated erosion/redistribution of soil resources by wind.

19. Conceptual model illustrating processes by which increasing site dominance by exotic annual grasses, grazing, soil-surface disturbances, off-site hydrologic function, and climate interactively can lead to accelerated erosion/redistribution of soil resources by water

20. Example of an annualized ecosystem at Arches National Park where climate-driven fluctuations in ground cover and persistent soil instability likely contribute to accelerated rates of wind erosion.

\section{Tables}

1. Selected characteristics of NPS units included in the Southern and Northern Colorado Plateau Networks.

2. Compensatory growth of plants in response to tissue removal

3. Structure, disturbance dynamics, distribution patterns, current status, and restoration needs of three contrasting types of piñon-juniper ecosystems in western North America...

\section{Appendix}

Appendix Table A. Primary functions and attributes/measures associated with components of dryland ecosystems.

Appendix Table B. Potential effects of major anthropogenic stressors on structure and functioning of dryland ecosystems

Appendix Table C. Climatic conditions, inherent ecosystem properties, and dynamic ecosystem properties hypothesized to confer resistance and resilience to selected ecosystem attributes in relation to particular disturbances or stressors 


\title{
The Structure and Functioning of Dryland Ecosystems- Conceptual Models to Inform Long-Term Ecological Monitoring
}

\author{
By Mark E. Miller
}

\section{Abstract}

The National Park Service (NPS) has undertaken the task of developing long-term ecological monitoring programs for 32 ecoregional networks of parks that have significant natural resources. As part of this effort, each network will select "vital signs" that are intended to represent the overall health or condition of park ecosystems, known or hypothesized effects of stressors, or elements that have important human values. As an aid to the consideration and selection of vital signs for long-term monitoring in NPS units of the Colorado Plateau region, this report presents a literature synthesis and a set of diagrammatic conceptual models that summarize existing knowledge and hypotheses concerning the structure and functioning of dryland ecosystems. These generalized conceptual models describe functional relationships among key structural components of dryland ecosystems; effects of climate, natural disturbances, and anthropogenic stressors on the functioning of selected ecosystem processes; and how these drivers of ecosystem change interact to produce particular patterns of ecosystem dynamics. Because NPS policies dictate that monitoring data will be used to help sustain the integrity of park ecosystems, conceptual models in this report emphasize common processes and pathways of dryland degradation - with the intent that this emphasis will best highlight ecosystem attributes that should be monitored for purposes of sustaining ecosystem integrity. Although developed to support the identification of long-term monitoring needs in NPS units, information in this report is broadly applicable well beyond NPS management boundaries and should be of use to other organizations or persons involved in management, conservation, and monitoring of dryland ecosystems in the Colorado Plateau or bordering ecoregions.

\section{Acknowledgments}

This work was supported by the National Park Service (Southern Colorado Plateau and Northern Colorado Plateau Inventory \& Monitoring Networks), the U.S. Geological Survey (the Southwest Biological Science Center and the Status and Trends Program of the Biological Resources Discipline and the Earth Surface Dynamics Program of the Geologic Discipline), and the U.S. Bureau of Land Management (Grand StaircaseEscalante National Monument). Conversations with Jayne Belnap, Jeff Herrick, Brandon Bestelmeyer, Joe Truett, Lisa Thomas, Richard Reynolds, Jason Neff, Marith Reheis, and Thom O'Dell contributed to ideas presented herein, although all of the errors and oversimplifications are solely mine. Review comments from Craig Allen, David Breshears, Greg Eckert, Denny Fenn, and David Pyke significantly improved the quality of the manuscript. Neil Cobb, George San Miguel, and Tamara Naumann assisted with figure captions. I thank Tina Kister, Craig Brunstein, and Christy Parry for their attention to detail in editing the manuscript, and Aneth Wight for map preparation. Finally, I thank Shelley Pistorius for the tremendous, wideranging support she provides to the staff of the Canyonlands Research Station, and Ann Welshko for her continued good humor, encouragement, and tolerance.

\section{Introduction and Background}

\section{Purpose and Content of This Report}

This report presents conceptual ecological models describing the structure and functioning of dryland ecosystems ${ }^{1}$ of the Colorado Plateau and bordering ecoregions of North America. These models and the associated literature review were prepared in support of the Southern Colorado Plateau Network (SCPN) of the National Park Service's

\footnotetext{
${ }^{1}$ An ecosystem is a spatially explicit unit of the Earth that includes all of the organisms, along with all components of the abiotic environment within its boundaries (Likens, 1992, cited by Christensen and others, 1996, p. 670). Ecosystem structure refers to the types, amounts, and spatial arrangement of biotic and abiotic components of an ecosystem. Ecosystem functioning refers to the flow of energy and materials through biotic and abiotic components of an ecosystem, and includes processes such as primary production, trophic transfer from plants to animals, nutrient cycling, water dynamics, and heat transfer (Díaz and Cabido, 2001).
} 
Inventory and Monitoring Program (NPS I \& M Program). In conjunction with the I \& M Program, ecoregional networks of NPS units have been tasked with the identification of "vital signs" to be monitored for the purpose of tracking long-term trends in the "health" or condition of park ecosystems. This report was developed for SCPN policymakers and researchers to help inform them in the consideration and selection of vital signs for dryland ecosystems in 19 NPS units located in the Colorado Plateau region of Utah, Arizona, Colorado, and New Mexico (table 1). The SCPN and the Northern Colorado Plateau Network (NCPN; consists of 16 NPS units) are working together closely to coordinate planning and implementation of their respective monitoring programs. As a consequence, this document also is intended to support the NCPN in the development of its monitoring plan and to facilitate the coordinated development of monitoring across both networks in the Colorado Plateau region. Although developed to support the identification of long-term monitoring needs in NPS units, information in this report is broadly applicable well beyond NPS management boundaries and should be of use to other organizations or persons involved in management, conservation, and monitoring of dryland ecosystems in the Colorado Plateau or bordering ecoregions.

This report begins with background information regarding the vital-sign concept, intended purposes of conceptual models in relation to ecosystem monitoring, and the geographical and ecological scope of the report. Following the background information section, a general conceptual model and literature review are presented to characterize important functional relationships among biotic and abiotic components of dryland ecosystems. In the third section, several additional models are presented to describe particular patterns and processes of dryland ecosystem dynamics that have significant implications for ecosystem monitoring and management. Models in this section emphasize common processes and pathways of dryland degradation — with the intent that this emphasis will best highlight ecosystem attributes that should be monitored for purposes of sustaining ecosystem integrity. Supplementary material is presented in accompanying appendix tables A-C.

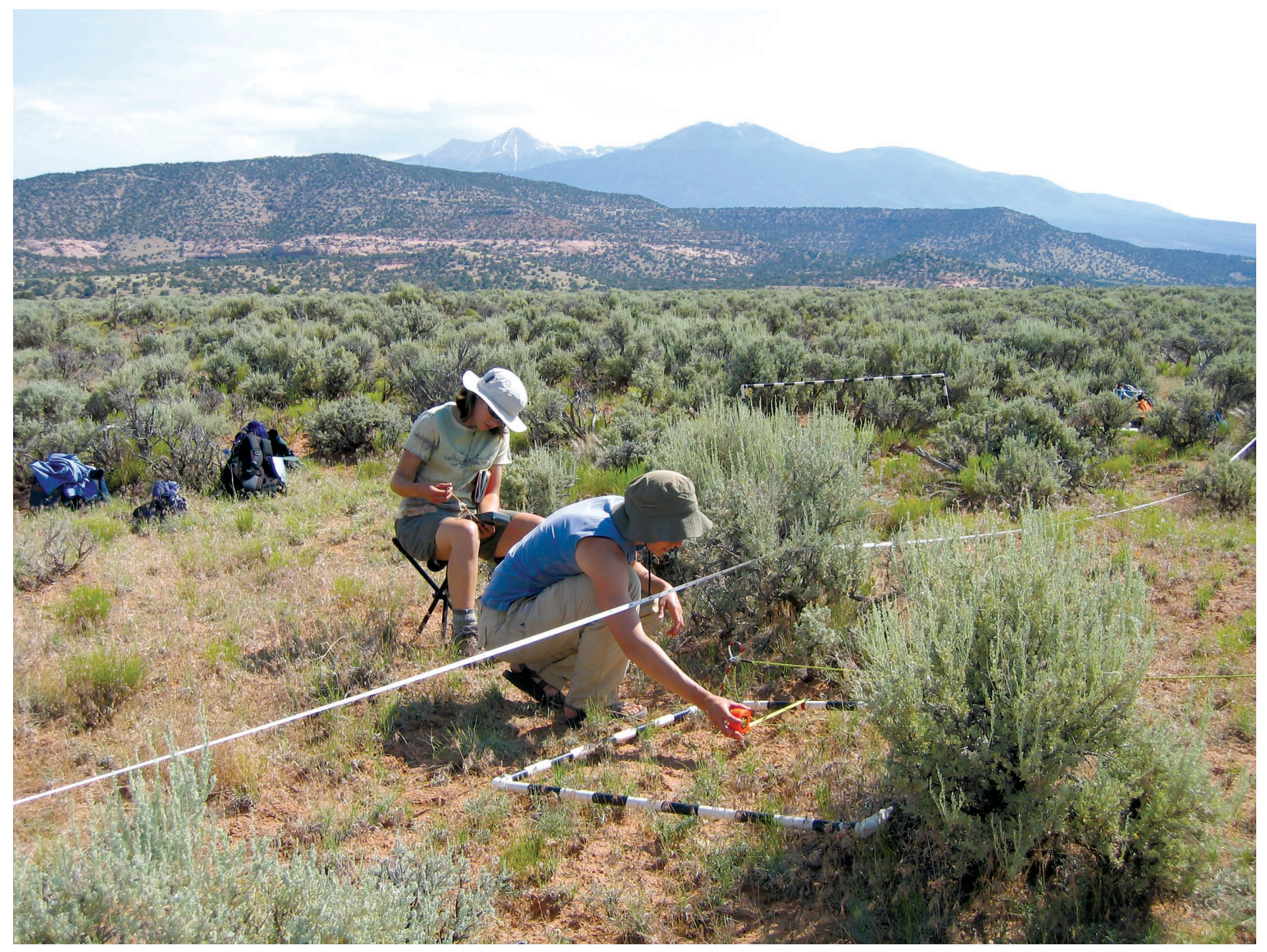

USGS plant ecologists evaluating sampling methods in support of the National Park Service Inventory and Monitoring Program. San Juan County, Utah. Photograph by Lisa Thomas, NPS. 
Table 1. Selected characteristics of NPS units included in the Southern and Northern Colorado Plateau Networks. Ecoregion designations follow The Nature Conservancy and NatureServe (Groves and others, 2002), as modified from Bailey (1995).

\begin{tabular}{|c|c|c|c|c|c|}
\hline Network/Park & Code & State & Size (ha) & Altitude (m) & Ecoregion \\
\hline \multicolumn{6}{|c|}{ Southern Colorado Plateau Network } \\
\hline Aztec Ruins National Monument & AZRU & NM & 130 & $1705-1764$ & Colorado Plateau \\
\hline Bandelier National Monument & BAND & NM & 13,254 & $1626-3081$ & Southern Rocky Mts. \\
\hline Canyon de Chelly National Monument & $\mathrm{CACH}$ & $\mathrm{AZ}$ & 37,448 & $1687-2336$ & $\begin{array}{c}\text { Colorado Plateau/Arizona-New } \\
\text { Mexico Mts. }\end{array}$ \\
\hline Chaco Culture National Historic Park & $\mathrm{CHCU}$ & NM & 14,090 & $1832-2096$ & Colorado Plateau \\
\hline El Malpais National Monument & ELMA & NM & 46,559 & $1950-2554$ & Arizona-New Mexico Mts. \\
\hline El Morro National Monument & ELMO & NM & 518 & $2183-2304$ & Arizona-New Mexico Mts. \\
\hline Glen Canyon National Recreation Area & GLCA & AZ/UT & 505,868 & $930-2319$ & Colorado Plateau \\
\hline Grand Canyon National Park & GRCA & $\mathrm{AZ}$ & 493,050 & $348-2798$ & Colorado Plateau \\
\hline Hubbell Trading Post National Historic Site & HUTR & $\mathrm{AZ}$ & 65 & $1920-1946$ & Colorado Plateau \\
\hline Mesa Verde National Park & MEVE & $\mathrm{CO}$ & 21,093 & $1833-2613$ & Colorado Plateau \\
\hline Navajo National Monument & NAVA & $\mathrm{AZ}$ & 146 & $1658-2294$ & Colorado Plateau \\
\hline Petrified Forest National Park & PEFO & $\mathrm{AZ}$ & 38,024 & $1618-1891$ & Colorado Plateau \\
\hline Petroglyph National Monument & PETR & NM & 2,915 & $1519-1838$ & Arizona-New Mexico Mts. \\
\hline Rainbow Bridge National Monument & RABR & UT & 65 & $1129-1492$ & Colorado Plateau \\
\hline Salinas Pueblo Missions National Monument & SAPU & NM & 433 & $1815-2058$ & Arizona-New Mexico Mts. \\
\hline Sunset Crater Volcano National Monument & SUCR & $\mathrm{AZ}$ & 1,227 & $2076-2441$ & Arizona-New Mexico Mts. \\
\hline Walnut Canyon National Monument & WACA & $\mathrm{AZ}$ & 1,456 & $1896-2106$ & Arizona-New Mexico Mts. \\
\hline Wupatki National Monument & WUPA & $\mathrm{AZ}$ & 14,350 & $1304-1744$ & Colorado Plateau \\
\hline Yucca House National Monument & YUHO & $\mathrm{CO}$ & 14 & $1767-1805$ & Colorado Plateau \\
\hline Total & & & $1,189,205$ & & \\
\hline \multicolumn{6}{|c|}{ Northern Colorado Plateau Network } \\
\hline Arches National Park & $\mathrm{ARCH}$ & UT & 30,966 & $1206-1725$ & Colorado Plateau \\
\hline Black Canyon of the Gunnison National Park & BLCA & $\mathrm{CO}$ & 12,159 & $1636-2752$ & Southern Rocky Mts. \\
\hline Bryce Canyon National Park & BRCA & UT & 14,502 & $2000-2777$ & Utah High Plateaus \\
\hline Canyonlands National Park & CANY & UT & 136,610 & $1140-2189$ & Colorado Plateau \\
\hline Capitol Reef National Park & CARE & UT & 97,895 & $1182-2730$ & Colorado Plateau \\
\hline Cedar Breaks National Monument & CEBR & UT & 2,491 & $2461-3247$ & Utah High Plateaus \\
\hline Colorado National Monument & COLM & $\mathrm{CO}$ & 8,310 & $1411-2160$ & Colorado Plateau \\
\hline Curecanti National Recreation Area & CURE & $\mathrm{CO}$ & 17,433 & $1982-2898$ & Southern Rocky Mts. \\
\hline Dinosaur National Monument & DINO & $\mathrm{CO} / \mathrm{UT}$ & 85,097 & $1442-2747$ & Utah-Wyoming Rocky Mts. \\
\hline Fossil Butte National Monument & FOBU & WY & 3,318 & $2012-2466$ & Wyoming Basins \\
\hline Golden Spike National Historic Site & GOSP & UT & 1,107 & $1317-1613$ & Great Basin \\
\hline Hovenweep National Monument & HOVE & $\mathrm{CO} / \mathrm{UT}$ & 318 & $1548-2056$ & Colorado Plateau \\
\hline Natural Bridges National Monument & NABR & UT & 3,009 & $1702-2019$ & Colorado Plateau \\
\hline Pipe Spring National Monument & PISP & $\mathrm{AZ}$ & 16 & $1495-1559$ & Colorado Plateau \\
\hline Timpanogos Cave National Monument & TICA & UT & 101 & $1669-2452$ & Utah-Wyoming Rocky Mts. \\
\hline Zion National Park & ZION & UT & 59,900 & $1112-2661$ & Colorado Plateau \\
\hline Total & & & 474,709 & & \\
\hline
\end{tabular}




\section{Vital Signs Definition}

As defined by the NPS (see http://science.nature.nps. gov/im/monitor/vsm.htm\#Definitions), vital signs are a subset of physical, chemical, and biological elements and processes of park ecosystems that are selected to represent the overall health or condition of park resources, known or hypothesized effects of stressors, or elements that have important human values. The elements and processes that are monitored are a subset of the natural resources that park managers are directed to preserve "unimpaired for future generations," including water, air, geological resources, plants and animals, and the various ecological, biological, and physical processes that act on those resources. Vital signs may occur at any level of the ecosystems including landscape, community, population, or genetic level, and may be compositional (referring to the variety of elements in the system), structural (referring to the organization or pattern of the system), or functional (referring to ecological processes). Although vital signs are used to support long-term monitoring in NPS units, they have relevance for other monitoring efforts useful for ecosystem management. ${ }^{2}$

\section{Purposes of Conceptual Models}

In the vital-sign selection process, conceptual models are used to summarize existing knowledge and hypotheses concerning the structure and functioning of park ecosystems. An important goal of the models is to depict how natural drivers (for example, climate) and anthropogenic stressors affect ecosystem structure and functioning. The ability of the monitoring program to detect the ecological effects of anthropogenic stressors is dependent upon interpreting trends in resource condition against the backdrop of natural ecosystem variation. Hypotheses concerning the effects of anthropogenic stressors on ecosystem structure and function must be grounded in an understanding of the relationship between natural drivers and the structure, functioning, and dynamics of ecosystems. Ecosystems can be characterized on the basis of far more structural and functional attributes than can be monitored affordably. Thus another important goal of the models is to guide the identification of a few important attributes that provide information about multiple aspects of ecosystem status (Noon, 2003).

No single conceptual model can satisfy all needs. Spatially explicit applications, such as ecological resource assessments, monitoring design, and landscape-level ecological modeling, ultimately require site-specific models, but monitoring programs also require generalized ecological models

\footnotetext{
${ }^{2}$ Ecosystem management is the process of land use decision making and land-management practice that takes into account organisms and processes that characterize and comprise the ecosystem and is based on the best understanding currently available as to how the ecosystem works. Ecosystem management includes a primary goal of sustainability of ecosystem structure and function, recognition that ecosystems are spatially and temporally dynamic, and acceptance of the dictum that ecosystem function depends on ecosystem structure and diversity (Dale and others, 2000, p. 642).
}

to facilitate communication among scientists, managers, and the public regarding ecosystems and how they are affected by human activities and natural processes. Together, the NPS and USGS have adopted an iterative approach of first developing general conceptual models for broadly defined ecosystem types, and then adapting and refining those models with sitespecific data concerning abiotic constraints, land use history, current condition, and specific patterns of ecosystem dynamics. Models presented in this report are generalized because of the great diversity of dryland ecosystems found in SCPN and NCPN parks.

Previous NPS reports established a framework for the conceptual modeling effort associated with the NCPN and SCPN monitoring programs (see Evenden and others, 2002; Thomas and others, 2003; Miller and others, 2003). The conceptual framework presented in these earlier documents provides a basis for the material included in this report, but it is not repeated here in detail.

\section{Geographical and Ecological Scope}

Given the distribution of parks included in the NCPN and SCPN, the geographic scope of this report extends from northern Utah and southwestern Wyoming southward to northcentral Arizona and New Mexico (fig. 1). This region is centered on the Colorado Plateau physiographic province, but the region also includes parts of the Wyoming Basin, the Southern and Central Rocky Mountains, and the Basin and Range physiographic provinces (Hunt, 1974). Park altitudes range from $348 \mathrm{~m}$ at the lower end of the Colorado River corridor in the Grand Canyon to 3,247 $\mathrm{m}$ at Cedar Breaks National Monument (NM) in southwestern Utah (table 1). Mean annual precipitation (MAP) at National Weather Service Cooperative Network (NWS) stations located in or near NCPN and SCPN parks ranges from $162 \mathrm{~mm}$ at Page, Arizona, to $752 \mathrm{~mm}$ at Cedar Breaks NM (fig. 1). Because this report focuses on characteristics of dryland ecosystems, it is generally restricted to those areas where MAP is less than $450 \mathrm{~mm}$-the upper limit for piñon-juniper vegetation (pygmy woodlands and forests dominated by Pinus edulis and Juniperus osteosperma) at Mesa Verde National Park (NP; Floyd, Colyer, and others, 2003). With the exception of the dry, high-elevation Gunnison Basin where Curecanti National Recreation Area (NRA) is located, areas receiving less than $450 \mathrm{~mm}$ in this region are generally found below 2,100-2,300 m altitude. Approximately 90-95 percent of NCPN park lands and 85-90 percent of SCPN park lands fall below these precipitation and altitude zones (estimated from data presented by Evenden and others, 2002, and Thomas and others, 2003). [See reports by Evenden and others (2002) and Thomas and others (2003) for additional park-specific information.] Dryland ecosystems within the scope of this report are characterized by mixtures of pygmy conifers (Juniperus and Pinus spp.), shrubs, dwarf shrubs, herbaceous plants, and biological soil crusts. Excluded from this report are montane shrublands (or "petran chaparral") and forests that are typically above the piñon-juniper zone. 


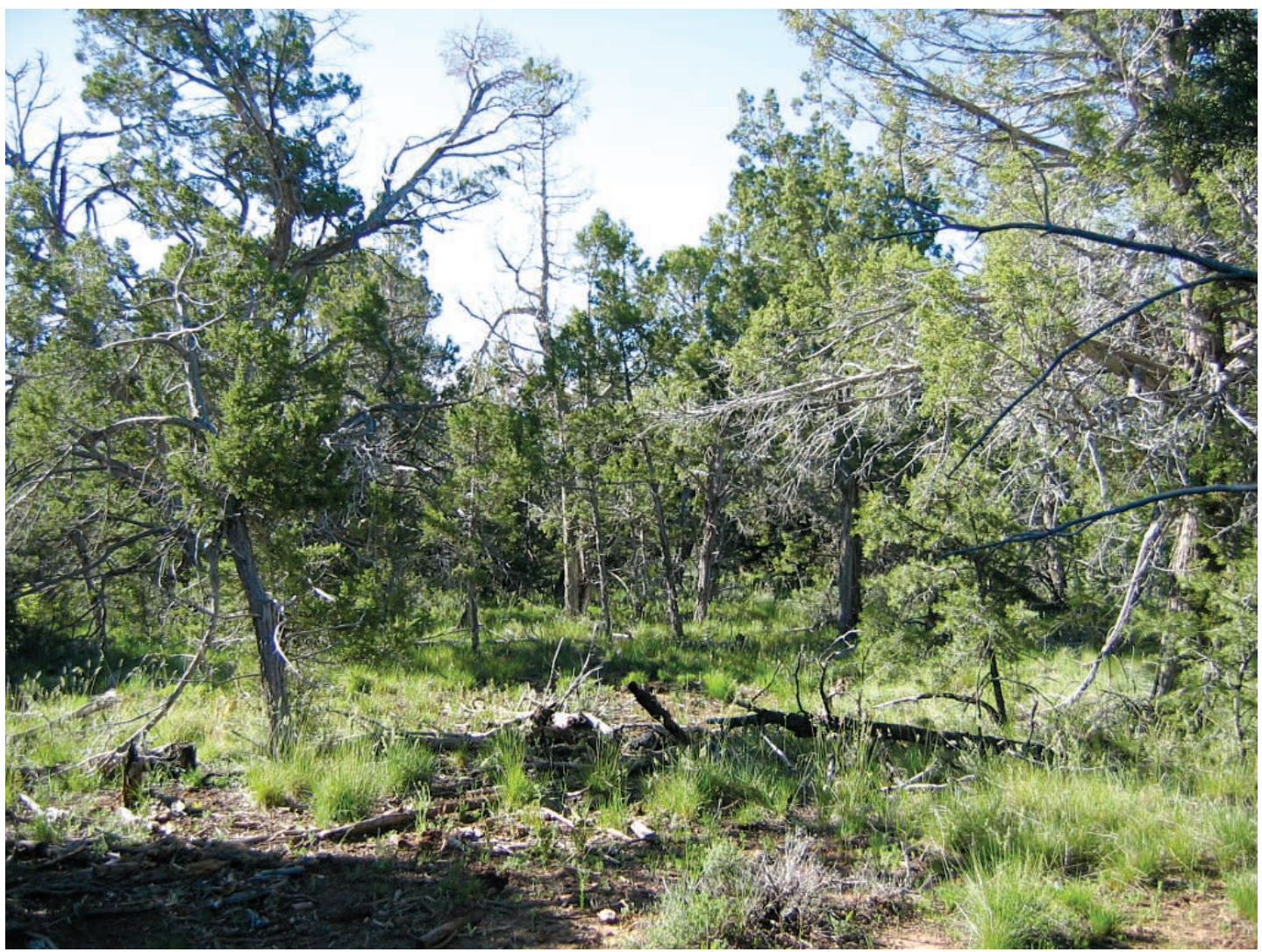

Piñon-Juniper woodland in Mesa Verde National Park, Colorado. Photograph by Mark Miller, USGS.

Characteristics and dynamics of these systems are addressed in a separate report (Vankat, 2004).

Across the geographic region included in the report, there is tremendous diversity in the composition, structure, and functioning of dryland ecosystems. This diversity is attributable to regional- and local-scale variations in climate, landforms, soils, and land use history. Variations in biogeographic history are reflected in the fact that the region also encompasses several distinct floristic areas (McLaughlin, 1986, 1989). As a consequence of these factors, SCPN and NCPN parks are found in seven broadly defined ecoregions (table 1, fig. 2).

Numerous schemes have been used to classify plant communities, ecosystems, and ecological land units of the region (for example, Küchler, 1964; Brown, 1982; Dick-Peddie, 1993; Spence and others, 1995; Creque and others, 1999; NatureServe, 2003; Comer and others, 2003). These schemes are based on various combinations of floristic, physiognomic, edaphic, topographic, and climatic parameters (Spence and others, 1995; Comer and others, 2003). Because this report focuses on ecosystem structure and function, it adopts a functional approach that generally corresponds with physiognomy rather than a particular classification scheme. On the basis of conceptual models presented below, this report concludes by offering recommendations concerning the type of classification best suited for the design of long-term monitoring in drylands.

\section{Structure and Functional Relationships}

This section begins with a brief overview of the ecosystem framework adopted by the SCPN and NCPN. Following this overview, a general conceptual model and literature review are presented to characterize important functional relationships among biotic and abiotic components of dryland ecosystems.

\section{Background: The Jenny-Chapin Model of Ecosystem Sustainability}

Jenny $(1941,1980)$ proposed that soil and ecosystem processes are determined by five state factors - climate, organisms, relief (topography), parent material, and time since disturbance. Jenny's state-factor approach has been widely applied as a framework for examining temporal and spatial variations in ecosystem structure and function (for example, Walker and Chapin, 1987; Vitousek, 1994b; Seastedt, 2001). Chapin and others (1996) recently extended this framework to develop a set of ecological principles concerning ecosystem sustainability. They defined "...a sustainable ecosystem as one that, over the normal cycle of disturbance events, maintains its characteristic diversity of major functional groups, productivity, and rates of 


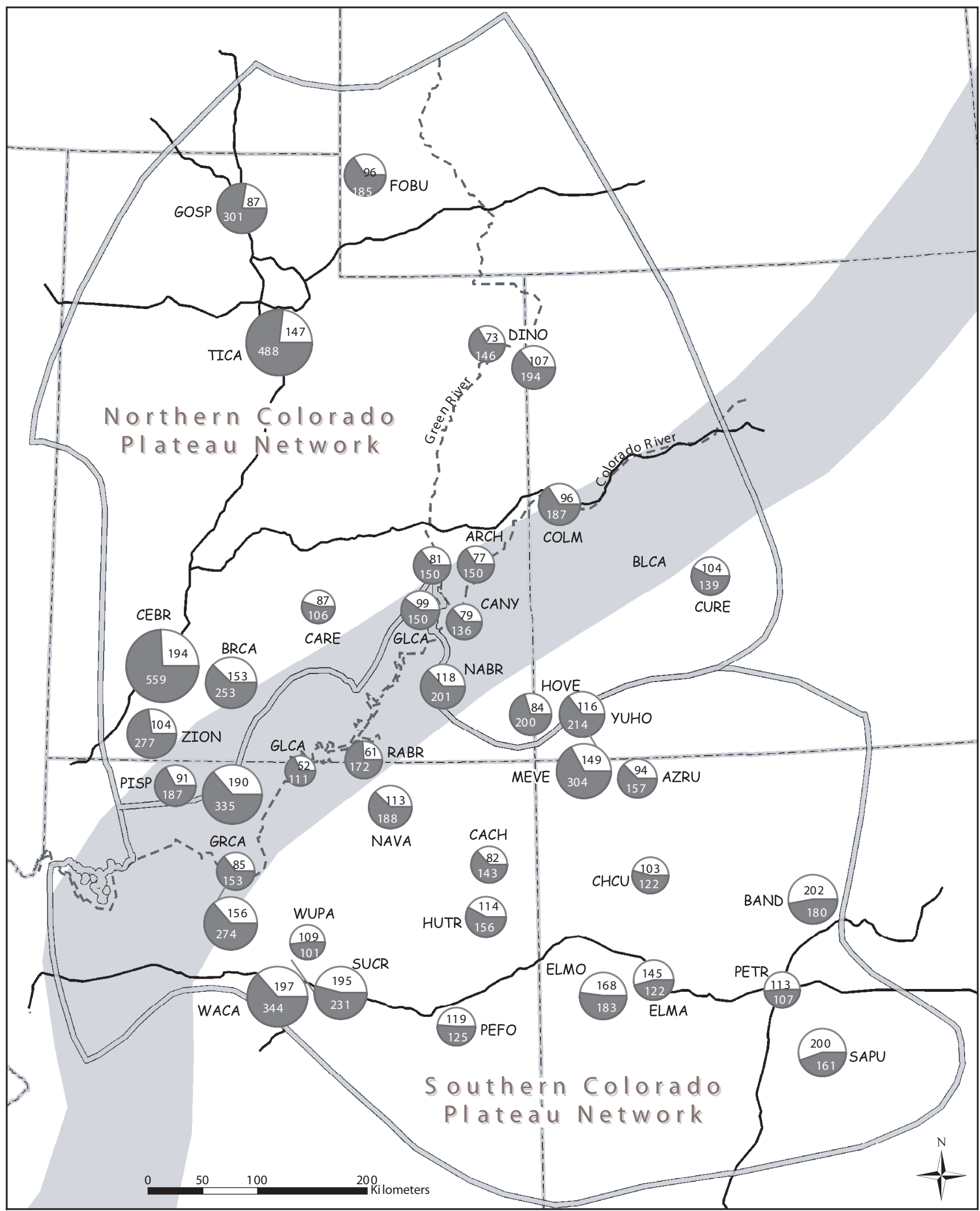

103 Mean June to September Precipitation (mm)

122 Mean October to May Precipitation (mm)

Symbol size scaled to indicate Mean Annual Precipitation

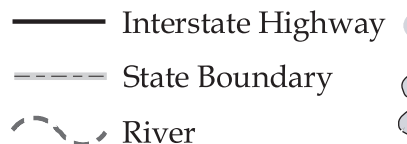

- - River
Monsoon Northern Boundary

$\sum$ Network Boundary 
Figure 1 (facing page). Map showing mean annual precipitation (symbol diameter) and mean seasonal precipitation (symbol segments) for National Weather Service Cooperative Network stations located at or near NPS units of the Southern and Northern Colorado Plateau Networks. Shaded zone approximates the mean northwestern extent of summer monsoon moisture (from Mitchell, 1976). Precipitation data were acquired from the Western Regional Climate Center (see http://www.wrcc.dri.edw climsum.html). See table 1 for key to four-letter park codes.

biogeochemical cycling" (Chapin and others, 1996, p. 1016). These ecosystem characteristics are determined by a set of four interactive controls - climate, soil-resource supply, major functional groups ${ }^{3}$ of organisms, and disturbance regime-and these interactive controls both govern and respond to ecosystem attributes. Interactive controls are constrained by the five state factors, which determine the constraints of place (Dale and others, 2000). The SCPN and NCPN have adopted a modified version of the Jenny-Chapin model as a general ecosystem framework for guiding the development of additional conceptual models, the consideration and selection of vital signs, and the design of long-term monitoring (fig. 3).

For long-term monitoring associated with goals of sustaining the health ${ }^{4}$ or integrity ${ }^{5}$ of ecosystems, a key aspect of the Jenny-Chapin model is the associated hypothesis that interactive controls must be conserved for an ecosystem to be sustained. Large changes in any of the four interactive controls are predicted to result in a new ecosystem with different characteristics than the original system (Chapin and others, 1996). For example, major changes in soil resources (for example, through erosion or other mechanisms) can greatly affect productivity, recruitment opportunities, and competitive relationships of plants, and thus can cause significant change to the structure and functioning of plant communities and higher trophic levels. Changes in vegetation structure can affect the ecosystem's disturbance regime through altered fuel characteristics. These factors and processes in combination can result in an altered system which is fundamentally different from the original system in terms of structure, functioning, and dynamics.

\footnotetext{
${ }^{3}$ Functional groups are groups of species that have similar effects on ecosystem processes (Chapin and others, 1996). This concept is generally synonymous with functional types.

${ }^{4}$ Ecosystem health is a metaphor pertaining to the assessment and monitoring of ecosystem structure, function, and resilience in relation to the notion of ecosystem sustainability (following Rapport, 1998, and Costanza and others, 1998). A healthy ecosystem is sustainable.

${ }^{5}$ Ecological integrity is a concept that expresses the degree to which the physical, chemical, and biological components (including composition, structure, and process) of an ecosystem and their relationships are present, functioning, and capable of self-renewal. Ecological integrity implies the presence of appropriate species, populations and communities and the occurrence of ecological processes at appropriate rates and scales as well as the environmental conditions that support these taxa and processes (http://science.nature.nps. gov/im/monitor/Glossary.htm).
}

\section{General Model}

Expanding on the framework of the Jenny-Chapin model, figure 4 serves as a general conceptual model describing structural components and functional relationships that characterize dryland ecosystems. Climatic and atmospheric conditions, soil resources, major functional groups, and disturbance regimes characteristic of dryland ecosystems are reviewed in this section. (Appendix table A provides a tabular supplement to fig. 4.)

\section{Regional Climatic and Atmospheric Conditions}

\section{Precipitation Regime}

Precipitation regime is the most important climatic factor defining the characteristics of dryland ecosystems because of the importance of precipitation inputs for driving water-limited ecological processes such as primary production, nutrient cycling, and plant reproduction (Noy-Meir, 1973; Comstock and Ehleringer, 1992; Whitford, 2002). Precipitation seasonality (that is, timing in relation to the annual cycle of potential evapotranspiration) and form (that is, snow versus rain) are particularly important attributes because they strongly control the partitioning of precipitation among various compartments of the hydrologic budget-evaporation, transpiration, runoff, drainage, and soil-water storage. Because of their effects on hydrologic partitioning, precipitation seasonality and form are major determinants of ecosystem dominance by different vegetative life forms and functional groups (Comstock and Ehleringer, 1992).

In the area encompassed by this report, precipitation seasonality varies regionally due to the influence of the Arizona monsoon (Mitchell, 1976; Peterson, 1994). The Arizona monsoon (also referred to as the "southwest monsoon" or the "Mexican monsoon") is recognized by climatologists as the northernmost part of an extensive summer monsoon region that extends to central Mexico and the western slopes of the Sierra Madre Occidental (Higgins and others, 1998). Areas affected by monsoon circulation receive greater amounts of summer precipitation from moist air masses derived from the Gulfs of Mexico and California. Notably, the mean northwestern extent of summer monsoon moisture is approximated by a band which cuts across the Colorado Plateau (fig. 1). Areas that are well northwest of this band are dominated by cool-season precipitation (for example, Golden Spike National Historic Site, Timpanogos Cave NM, and Fossil Butte NM), whereas areas that are southeast of this band (for example, Bandelier NM, El Malpais NM, and Salinas Pueblo Missions NM) receive higher amounts of summer monsoon precipitation from convective thunderstorms. Areas close to the band are generally characterized by a bimodal precipitation regime, with summer monsoon precipitation that is highly variable from year to year.

Ehleringer and others (1999) hypothesized that effects of global change on atmospheric circulation patterns and precipitation may be seen relatively early in the Colorado Plateau region because of the presence of this significant climatic 


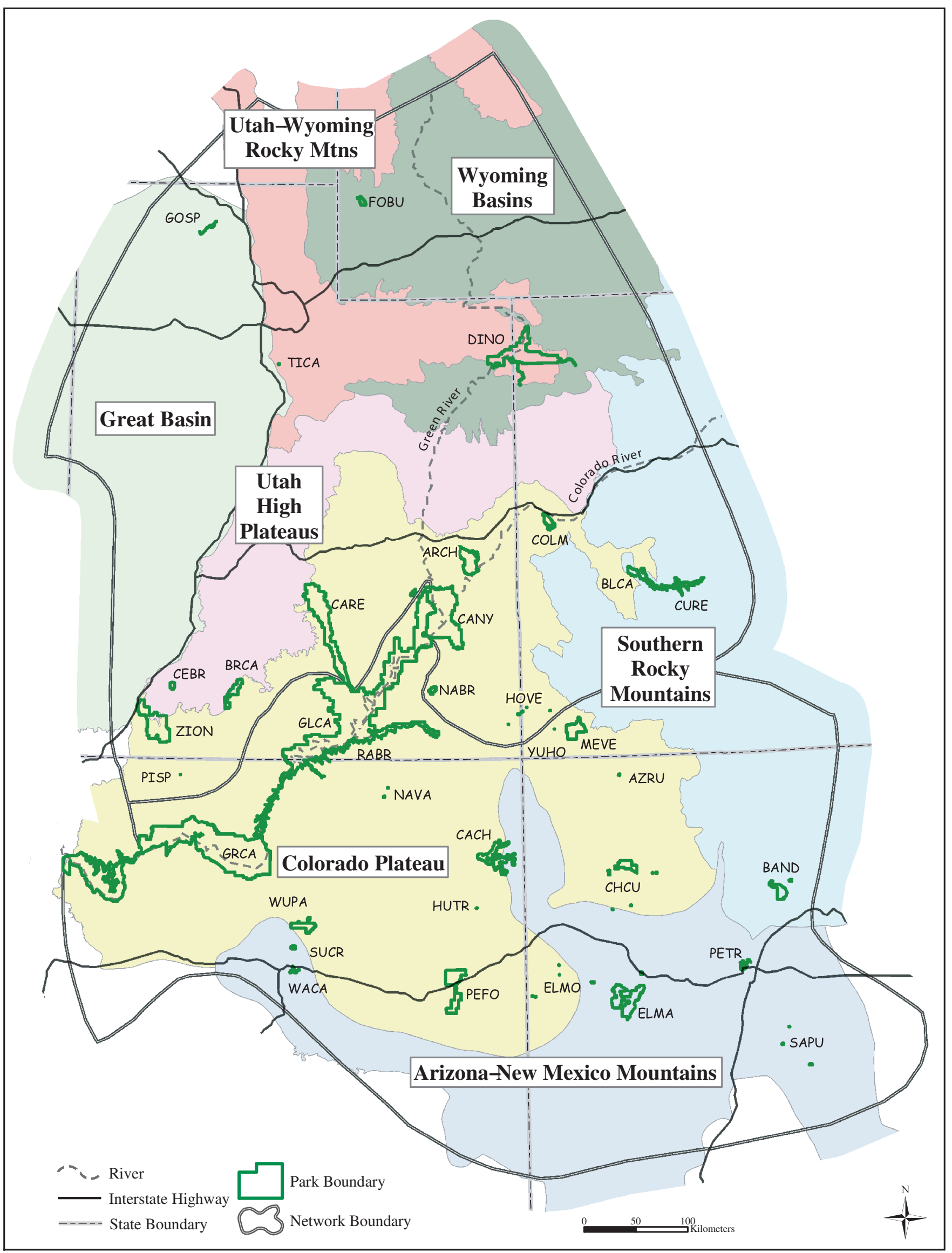


Figure 2 (facing page). Map showing location of NCPN and SCPN parks in relation to ecoregions. Ecoregion designations follow The Nature Conservancy and NatureServe (Groves and others, 2002), as modified from Bailey (1995). See table 1 for key to four-letter park codes.

boundary. In an analysis of regional precipitation trends for the central Colorado Plateau, Spence (2001) found that there has been a weak trend towards increasing winter precipitation but no evidence for significant changes in monsoon precipitation patterns since the 1960's. Annual minimum temperatures were found to have increased significantly across the region during the same time period (Spence, 2001).

Regional precipitation patterns are affected by globalscale fluctuations in sea-surface temperatures, atmospheric pressure, and atmospheric circulation patterns that vary at two different time scales (Hereford and others, 2002). Short-term interannual variations in precipitation are related in part to the occurrence of El Niño and La Niña conditions-the two contrasting phases of the El Niño-Southern Oscillation (ENSO) phenomenon that is driven by variations in sea-surface temperatures (SSTs) in the eastern tropical Pacific Ocean (Hereford and Webb, 1992; Cayan and others, 1999; Hereford and others, 2002). Hereford and others (2002) recently reported their analyses of $20^{\text {th }}$ century precipitation patterns on the Colorado Plateau in relation to ENSO phases. They found that the detailed relationships were complex, but that strong El Niño episodes generally increased the variability of warm-season precipitation or the frequency of above-normal cool-season precipitation. In contrast, strong La Niña episodes tended to cause normal, low-variability warm-season precipitation and below-normal cool-season precipitation. Whether characterized by dry or wet conditions, extreme years can have long-lasting consequences for ecosystem structure and functioning by causing episodes of plant mortality or establishment (Ehleringer and others, 1999).

Over decadal-scale time periods, spatial and temporal patterns in precipitation across the conterminous United States are related to phenomena known as the Pacific Decadal Oscillation (PDO) and the Atlantic Multidecadal Oscillation (AMO; Mantua and Hare, 2002; McCabe and others, 2004). The AMO is an index of SST variations over the North Atlantic Ocean, whereas the PDO reflects SST variations over the North Pacific Ocean (Mantua and Hare, 2002; McCabe and others, 2004). The PDO and AMO are quasiperiodic and may be caused by internal variations in oceanic circulation patterns and associated patterns of heat transport (McCabe and others, 2004). In their analyses of $20^{\text {th }}$-century data, McCabe and others (2004) found that 52 percent of the spatial and temporal variance in multidecadal drought frequency across the conterminous United States was attributable to variations in these two SST indices. Hereford and others (2002) analyzed $20^{\text {th }}$-century precipitation patterns on the Colorado Plateau and found evidence for three relatively distinct precipitation regimes that appeared to be in phase with the PDO. The first of these was a period of relatively wet conditions from 1905 to 1941. Notably, the onset of this wet period corresponds well with the pulse of ponderosa pine establishment that was documented throughout much of the Southwest during the first decades of this century (Cooper, 1960; Savage, 1991). Following this wet period, two other distinctly recognizable precipitation regimes occurred from 1942 to 1977 (dry) and from 1978 to 1998 (wet). The marked shift to dry conditions that began in 1999 and continues through the present suggests a transition to the dry PDO phase that could continue for the next $2-3$ decades (Hereford and others, 2002). This has important implications for ecosystem management and monitoring in the region due to the effects of precipitation patterns on disturbance regimes (Swetnam and Betancourt, 1998) and on the capacity of ecosystems to resist or recover from natural disturbances and human land use activities (Ehleringer and others, 1999; Whitford, 2002).

In addition to temporal variability, spatial variability is another defining attribute of dryland precipitation regimes (Noy-Meir, 1973; Whitford, 2002). Topography and storm type are two factors that control spatial variability in precipitation. On a local scale, precipitation tends to increase with increasing elevation due to orographic effects of topography (precipitation caused by adiabatic cooling of rising air masses), but rain shadows also can develop on the lee side of massive topographic features. Such rain-shadow effects can produce high-elevation zones of aridity like the Gunnison Basin in western Colorado. As for storm type, summer precipitation derived from convective thunderstorms is characterized by greater spatial variability than winter precipitation from frontal storms (Noy-Meir, 1973; Whitford, 2002).

The size of precipitation events also is an important attribute of dryland precipitation regimes (Noy-Meir, 1973; Sala and Lauenroth, 1982; Lauenroth and Sala, 1992; Ehleringer and others, 1999; Whitford, 2002; Austin and others, 2004; Loik and others, 2004). Event size and timing (seasonal, diurnal, and in relation to antecedent environmental conditions) in combination are important for determining ecological responses to precipitation due to effects on hydrologic partitioning. A significant characteristic of dryland precipitation regimes is the predominance of small events (for example, see fig. 5). Depending on environmental conditions, small events $(<5 \mathrm{~mm})$ may trigger soil-surface processes such as nutrient mineralization/volatilization, whereas larger events may be required to initiate seed germination, plant physiological processes such as photosynthesis, and hydrologic processes such as soil-water recharge (Ehleringer and others, 1999). The capacity to respond to precipitation events of different sizes and timing is an important ecophysiological characteristic of plants that determines their ability to persist under particular precipitation regimes (Sala and Lauenroth, 1982; Ehleringer and others, 1999).

Precipitation intensity (amount per unit time period) also affects hydrologic partitioning of precipitation. Precipitation intensity, soil characteristics (for example, texture and antecedent moisture conditions), and soil-surface features (for 
A

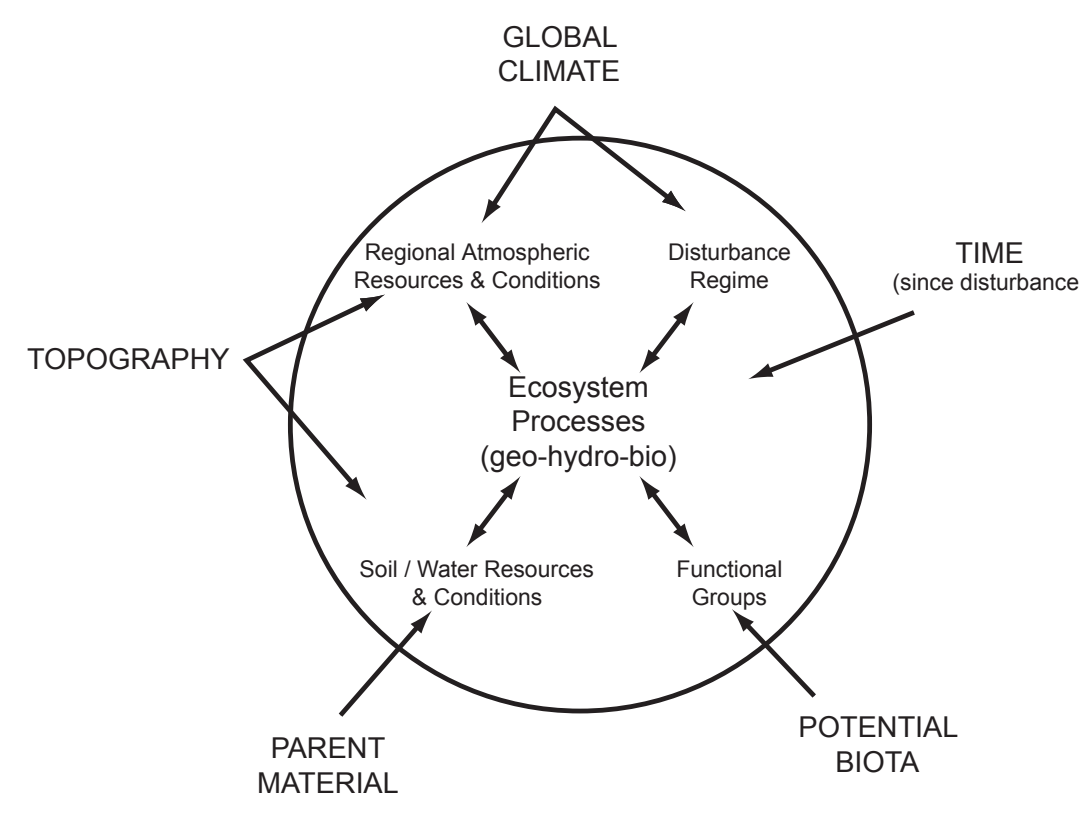

$B$

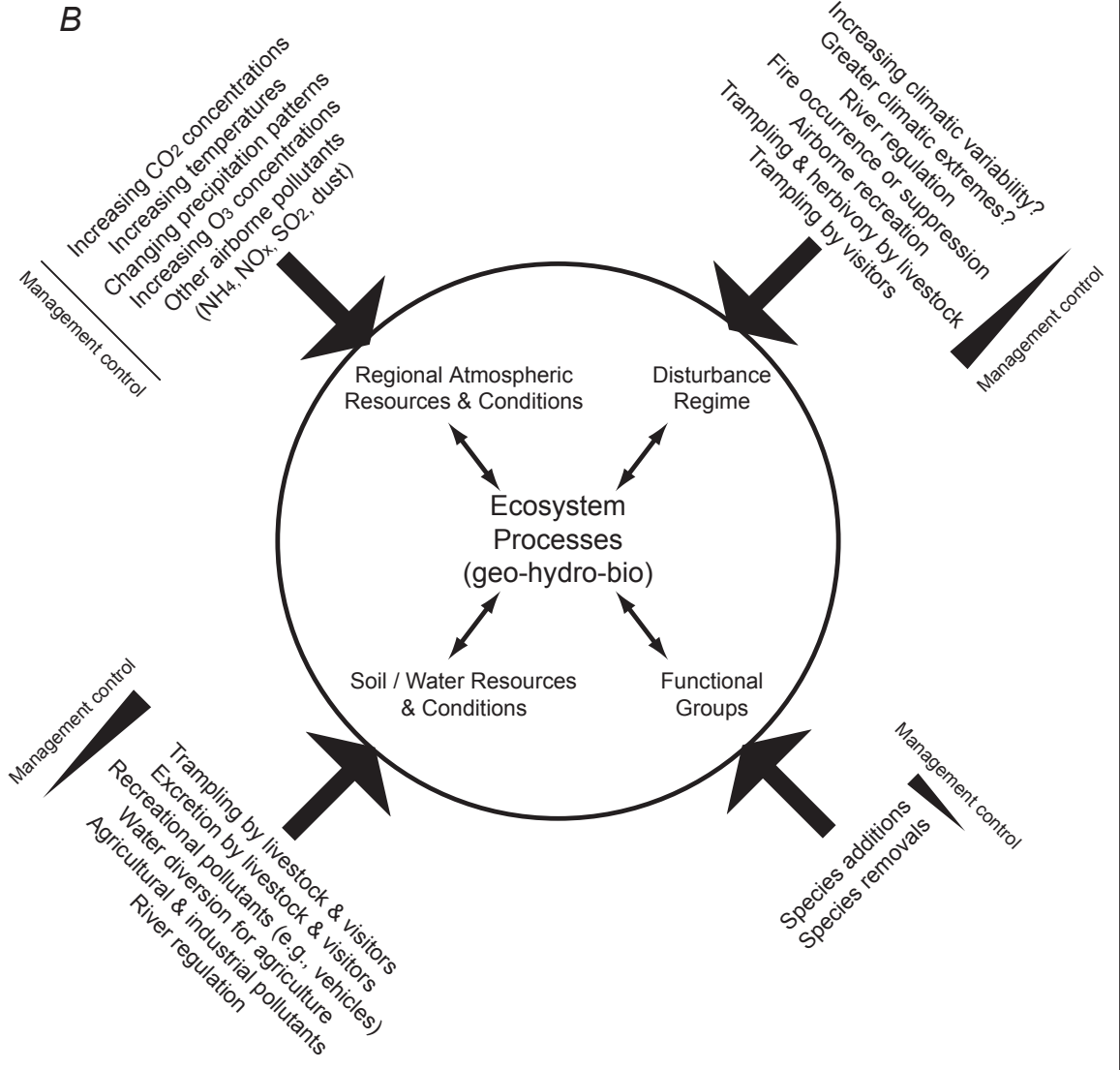

Figure 3. Modified version (A) of the Jenny-Chapin model that serves as the general ecosystem model for the SCPN and NCPN (redrawn with permission from The American Naturalist and The University of Chicago Press; Chapin and others, 1996) and $(B)$ the array of stressors affecting SCPN/NCPN ecosystems arranged in the model in relation to their first-order effects. Complex, higher order effects occur as the four major controls interact via ecosystem processes. The circle represents the boundary of the ecosystem. 


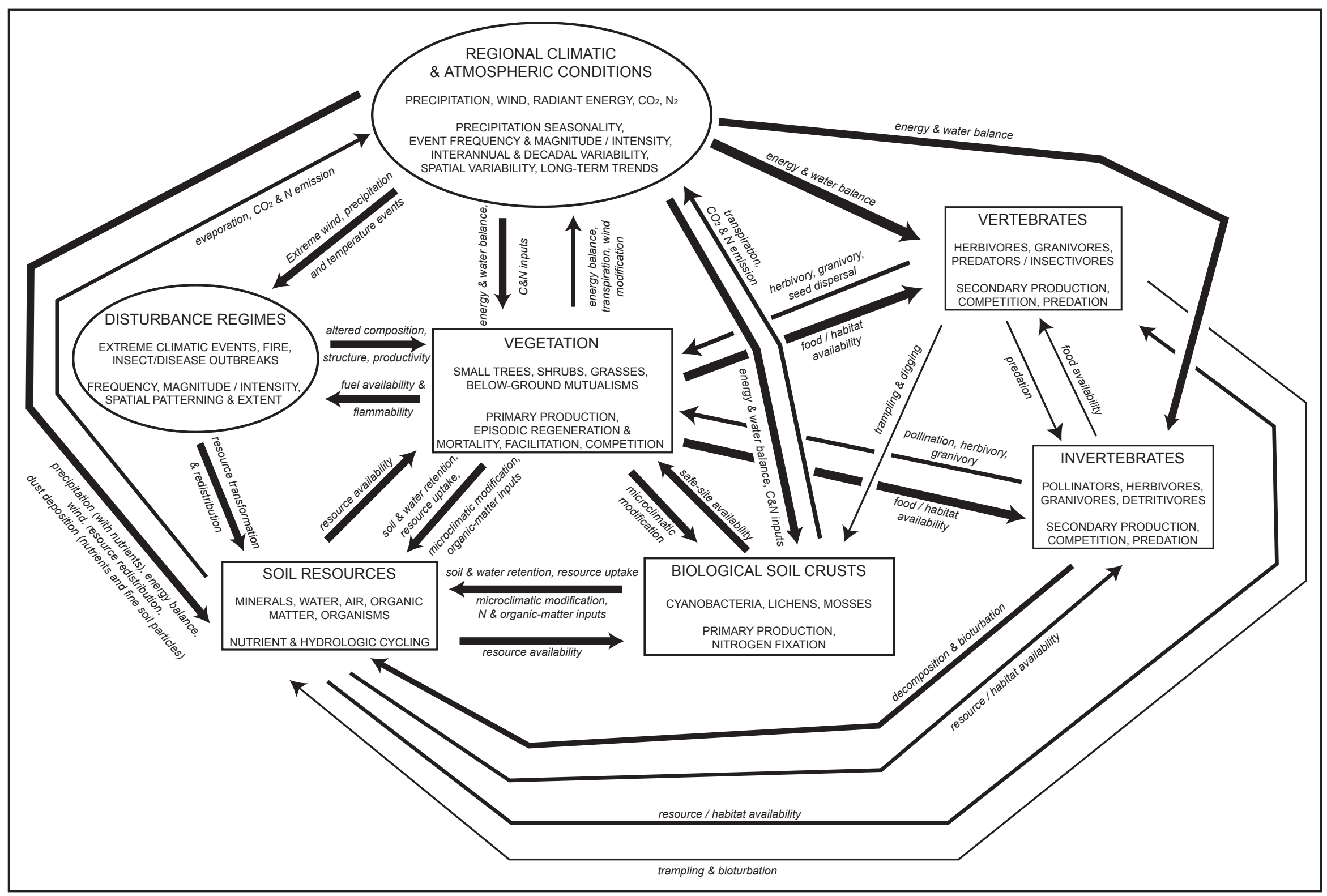

Figure 4. General conceptual model depicting the structure and functioning of dryland ecosystems. Ovals indicate major drivers of ecosystem change and temporal variability, as well as important attributes of drivers. Boxes indicate major structural components and important processes. Arrows indicate functional relationships among components, and line weights indicate relative importance of relationships. The model is constrained by global climatic and atmospheric conditions, topography, parent material, potential biota, and time. 


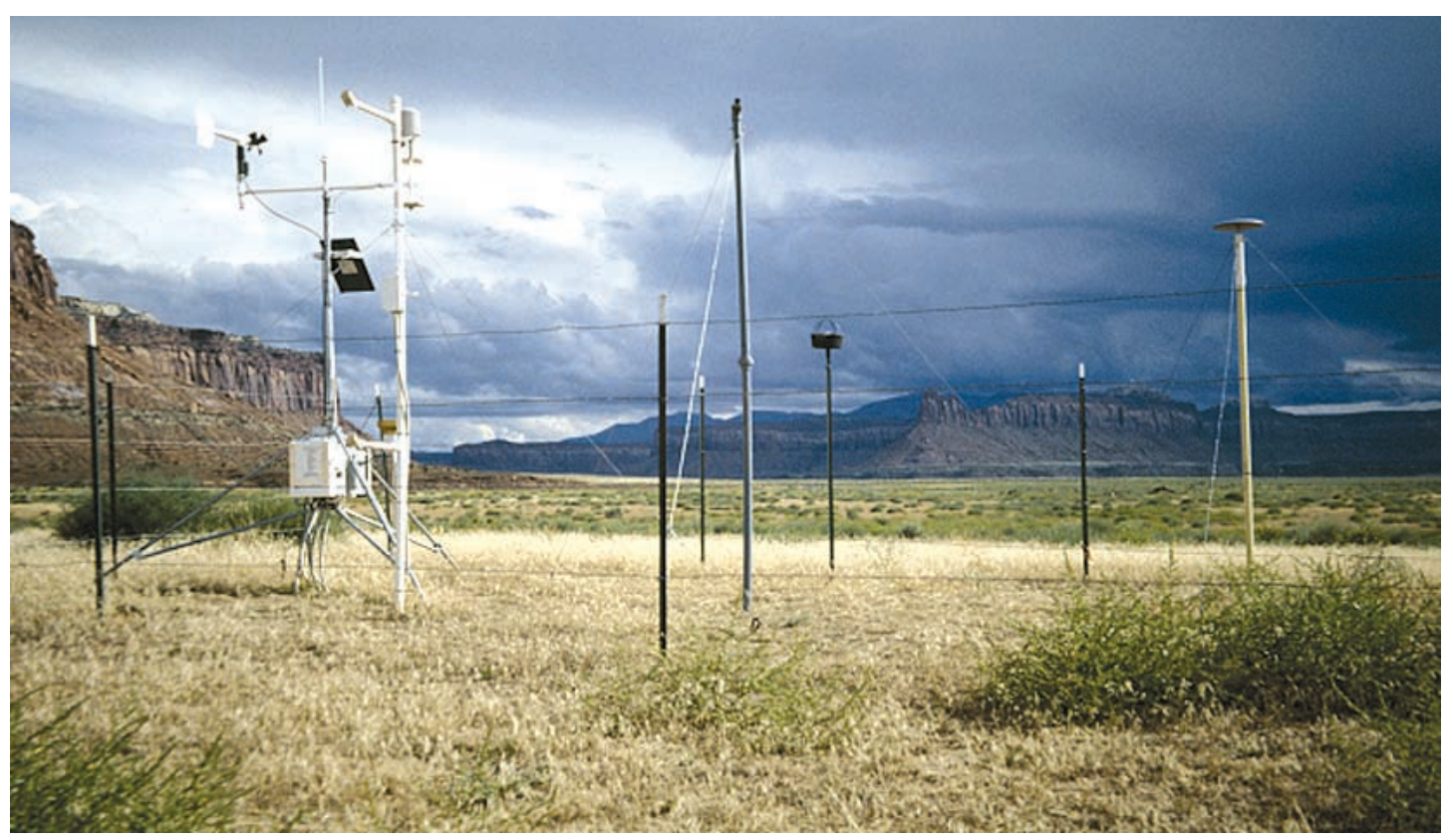

USGS meteorological station established to monitor climate (temperature, precipitation, wind direction and strength) and geologic processes (erosion and deposition) for studies of land use and landscape change on the Colorado Plateau (USGS Earth Surface Dynamics Program, http://climweb.cr.usgs.gov/info/sw/clim-met)). San Juan County, Utah. Photograph by Rich Reynolds, USGS.

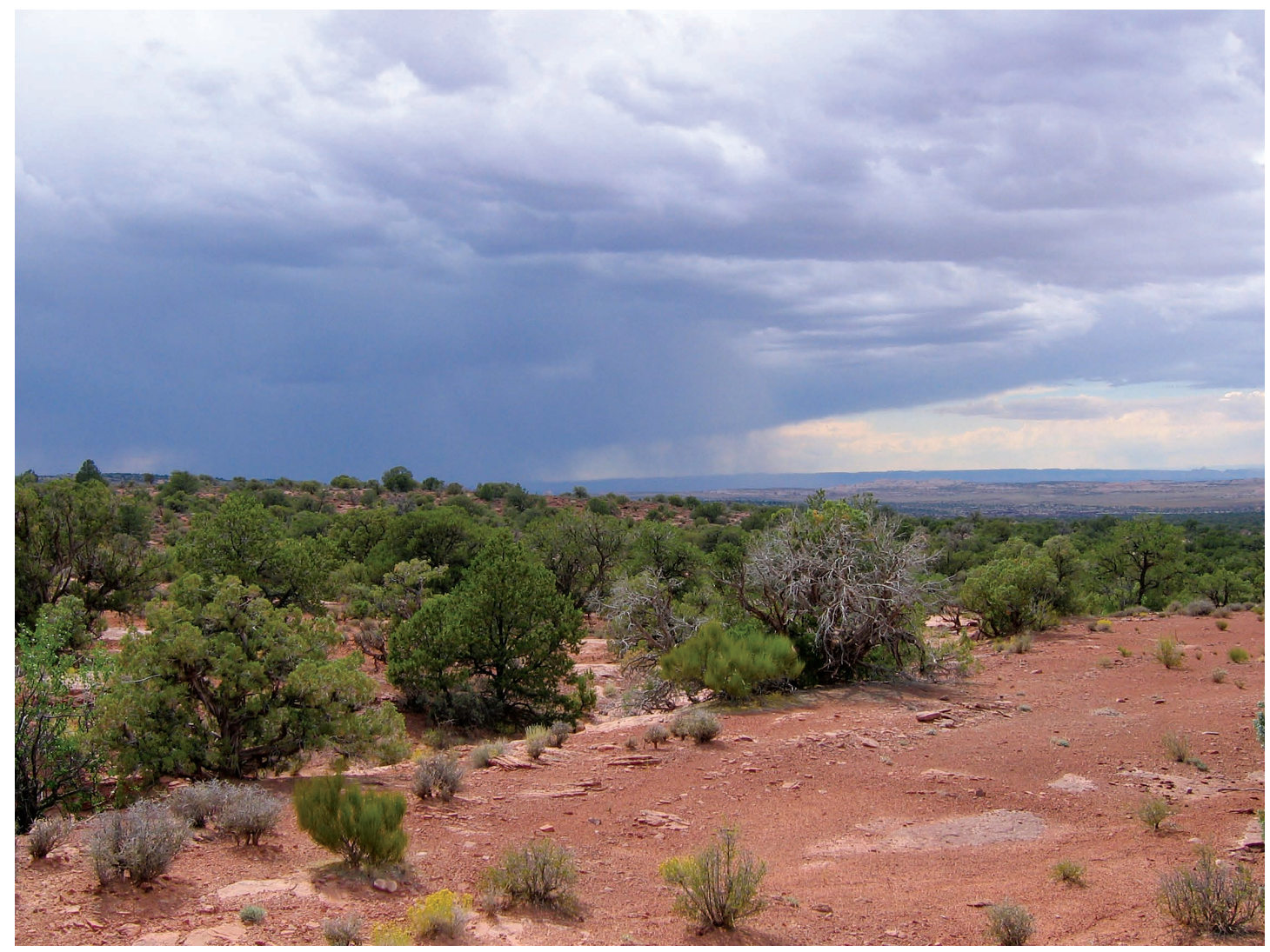

Summer rainstorm on the Colorado Plateau, Grand County, Utah. Photograph by Brad Wilcox, Texas A\&M University. 
example, soil-surface roughness; amount, type, and distribution of ground cover) together determine whether precipitation events result in infiltration or runoff (Whitford, 2002; Breshears and others, 2003). If precipitation intensity exceeds the soil infiltration rate, runoff will be generated-increasing the potential for soil erosion. In the Colorado Plateau region, precipitation intensity tends to increase with increasing elevation and decreasing latitude (fig. 6), because these variables together generally indicate relative exposure to high-intensity convective thunderstorms. Results of regression analyses indicate that about two-thirds of the variation in precipitation intensity ${ }^{6}$ across the region can be explained by elevation and latitude $\left(\mathrm{F}=2,29 ; \mathrm{R}^{2}=0.66, \mathrm{p}<0.001\right)$.

${ }^{6}$ The intensity measure used in this analysis was the estimated maximum intensity of precipitation $(\mathrm{mm} / \mathrm{hr})$ expected to occur over a 5-minute period with 50 percent probability during any given year at NWS stations located at or near NCPN and SCPN units. Data were acquired in December 2003 from the National Oceanic and Atmospheric Administration's Precipitation Frequency Data Server (http://hdsc.nws.noaa.gov/hdsc/pfds/).
Studies conducted in some dryland ecosystems have found time lags in the response of above-ground net primary production (ANPP) to interannual variations in precipitation (Lauenroth and Sala, 1992; Oesterheld and others, 2001; Wiegand and others, 2004). For example, analyses of a 52-year-long data set from a short-grass steppe ecosystem in Colorado found that only 39 percent of the interannual variation in ANPP could be explained by current-year precipitation (Lauenroth and Sala, 1992). The best model, which accounted for 60 percent of ANPP variability, included precipitation from the current year and from the two previous years (Oesterheld and others, 2001). Due to this lag or carryover effect, ANPP fluctuations are buffered if wet and dry years alternate but amplified if multi-year sequences of dry and wet years occur (Oesterheld and others, 2001; Wiegand and others, 2004). Preliminary analyses of vegetation-monitoring data from Canyonlands NP suggest that production-precipitation lags also may occur in Colorado Plateau systems (J. Belnap, unpub. data, 2005).

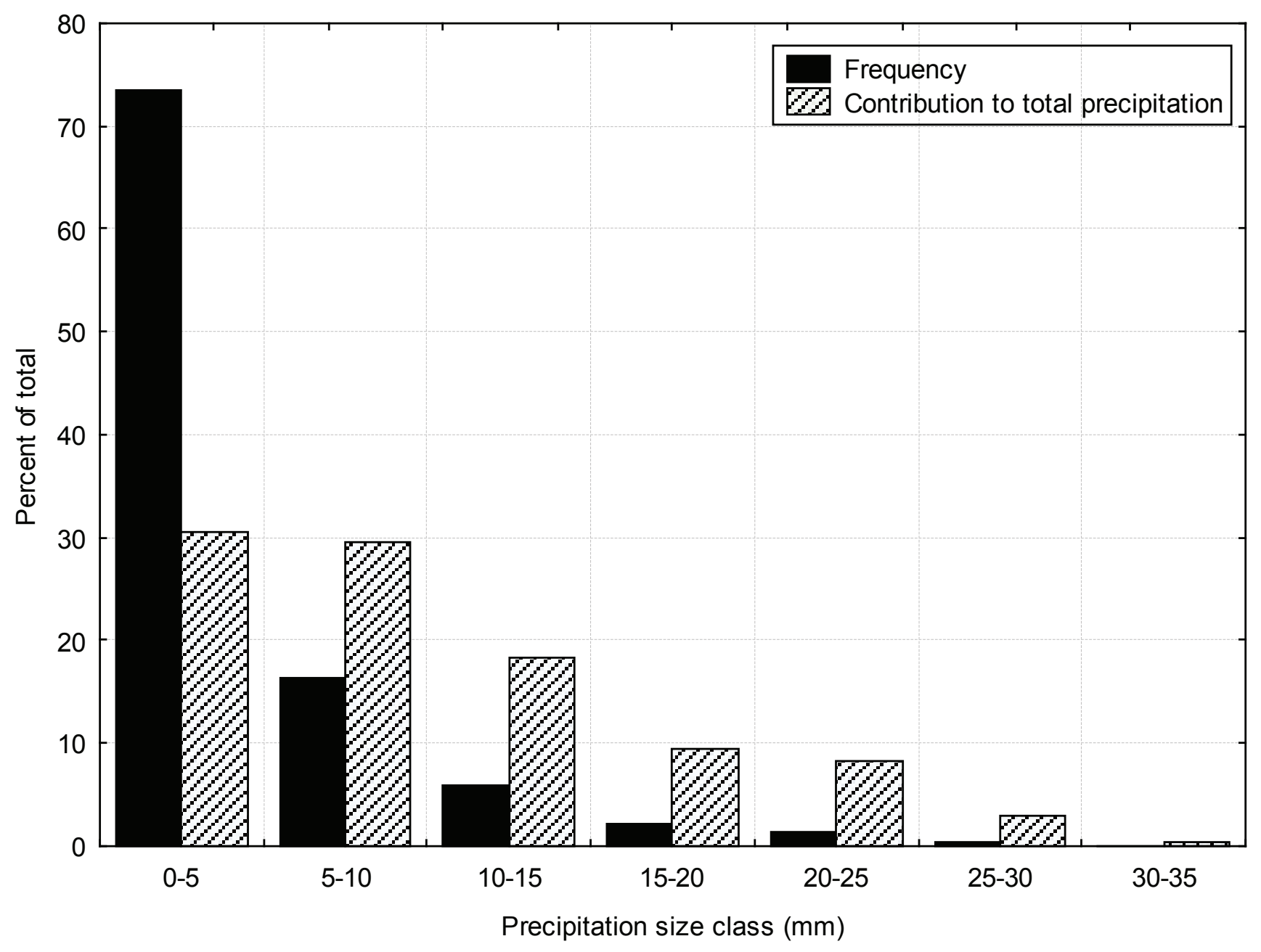

Figure 5. Distribution of precipitation events (based on daily values) by size class at the Needles District of Canyonlands National Park, 1965-1998. 

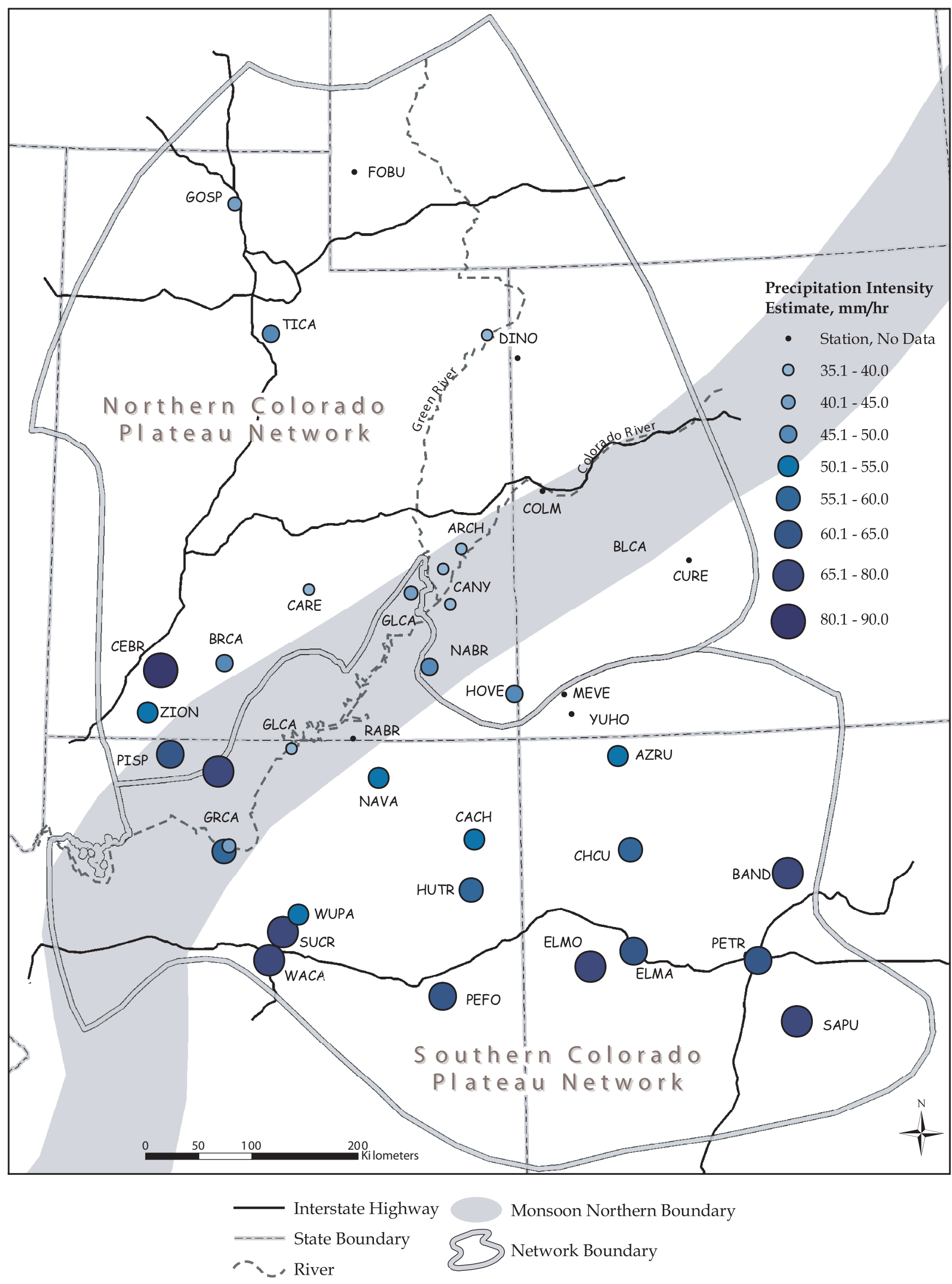
Figure 6 (facing page). Map depicting regional variations in the estimated maximum intensity of precipitation $(\mathrm{mm} / \mathrm{hr})$ that can be expected to occur over a 5-min period with 50 percent probability during any given year at NWS stations located at or near NCPN and SCPN units. Shaded zone approximates the mean northwestern extent of summer monsoon moisture (from Mitchell, 1976). Data were acquired from NOAA's Precipitation Frequency Data Server (see http://hdsc.nws.noaa.gov/hdsc/pfds/). See table 1 for key to four-letter park codes.

\section{Wind}

Wind is another atmospheric phenomenon that can have important effects on the structure and functioning of dryland ecosystems. As a driver of near-surface air circulation, wind strongly affects evapotranspiration rates and thus can modify the energy and water balances of plants and soils (Larcher, 1995). Like precipitation, wind also is an important force driving the redistribution of soil resources both within and among ecosystems (Whicker and others, 2002). In a recent comparison of wind- and water-driven erosion (off-site redistribution of soil resources) and horizontal transport (within-site redistribution of soil resources) in dryland ecosystems, Breshears and others (2003) estimated that wind erosion exceeded water erosion by about 33 times at a shrubland site and by about five times at a forest site. At a grassland site, the authors estimated that water erosion was about three times greater than wind erosion. Horizontal transport by wind was greater than that by water in all three systems, including a 2,200-fold difference in the shrubland. Soil texture, vegetation structure, and ground cover were important variables affecting among-site differences in the relative importance of wind and water erosion and transport. The frequency-intensity distributions of process-driving wind and precipitation events are climatic factors that also affect the importance of wind versus water erosion and transport on particular sites (Breshears and others, 2003). Finally, wind also interacts with topography to influence fire behavior and is a major factor determining whether a wildfire can be contained or whether it will spread explosively across the landscape (see Peters and others, 2004).

\section{Soil Resources}

\section{Inherent Edaphic Heterogeneity}

Soil resources, including mineral nutrients, organic matter (including litter), water, and soil biota, are fundamental determinants of ecosystem structure and function (Jenny, 1980; Vitousek, 1994b; Reynolds and others, 2003). A characteristic feature of soils in the Colorado Plateau region is tremendous spatial heterogeneity attributable to combined effects of geology, topography, and geomorphic processes (Brotherson and others, 1985; Norton and others, 2003). Due to low rates of weathering and pedogenic processes in dryland environments, the relative importance of parent material as a factor determining soil properties generally increases with aridity (Jenny, 1941). Geologic and climatic features of Colorado Plateau drylands have produced weakly developed soils with physical and chemical characteristics that closely match the shales, sandstones, limestones, and igneous materials from which they were derived. Geomorphic processes, such as erosion and deposition, have built upon this geologic template to generate abrupt or gradational juxtapositions of landforms and soils differentiated on the basis of soil depth, particlesize distributions, mineralogy, and degree of profile development (Schimel and others, 1985; Daniels and Hammer, 1992; Birkeland, 1999; Norton and others, 2003). Effects of human activities (Amundson and Jenny, 1991) and aeolian dust inputs (Reynolds and others, 2001) are superimposed on this mosaic. Whereas disturbances such as fire often are the primary factors responsible for generating landscape patterns in comparatively mesic environments (Clark, 1991), inherent edaphic heterogeneity is a primary cause of landscape patterns in dryland parts of the Colorado Plateau region.

\section{Soil Functions and Soil Quality}

Soils perform several ecological functions pertinent to ecosystem management and monitoring. Soils regulate hydrologic processes and the cycling of mineral nutrients. As a medium for storage and delivery of water and nutrients, soils also sustain the existence and productivity of plant and animal populations. The capacity of a specific kind of soil to perform these functions is described by the concept of soil quality (Karlen and others, 1997; Herrick and others, 2002; Norfleet and others, 2003). Soil quality and soil functioning are determined by relatively static soil properties, such as texture, depth, and mineralogy, and by relatively dynamic soil properties, such as organic-matter content, aggregate stability, soilsurface roughness, and structure (Seybold and others, 1999). Compared with soil properties that are relatively static over management time frames, dynamic soil properties are more subject to change under the influence of climatic fluctuations, land use activities, natural disturbances, and management actions. But even soil properties such as depth and texture can change as a consequence of erosion (Neff and others, 2005).

Within a given climatic region, soil is the most important factor affecting the structure of terrestrial ecosystems because of its role in mediating the bioavailability of water and mineral nutrients (Whitford, 2002). This is particularly true of dryland ecosystems because small differences in soil physical and chemical traits can have relatively large effects on water and nutrient bioavailability (Comstock and Ehleringer, 1992; McAuliffe, 2003).

\section{Resource Limitations}

In general, water has been described as the soil resource that most commonly limits the productivity of dryland ecosystems (Noy-Meir, 1973; Ehleringer and others, 1999). But there is increasing recognition that nutrients also can limit 


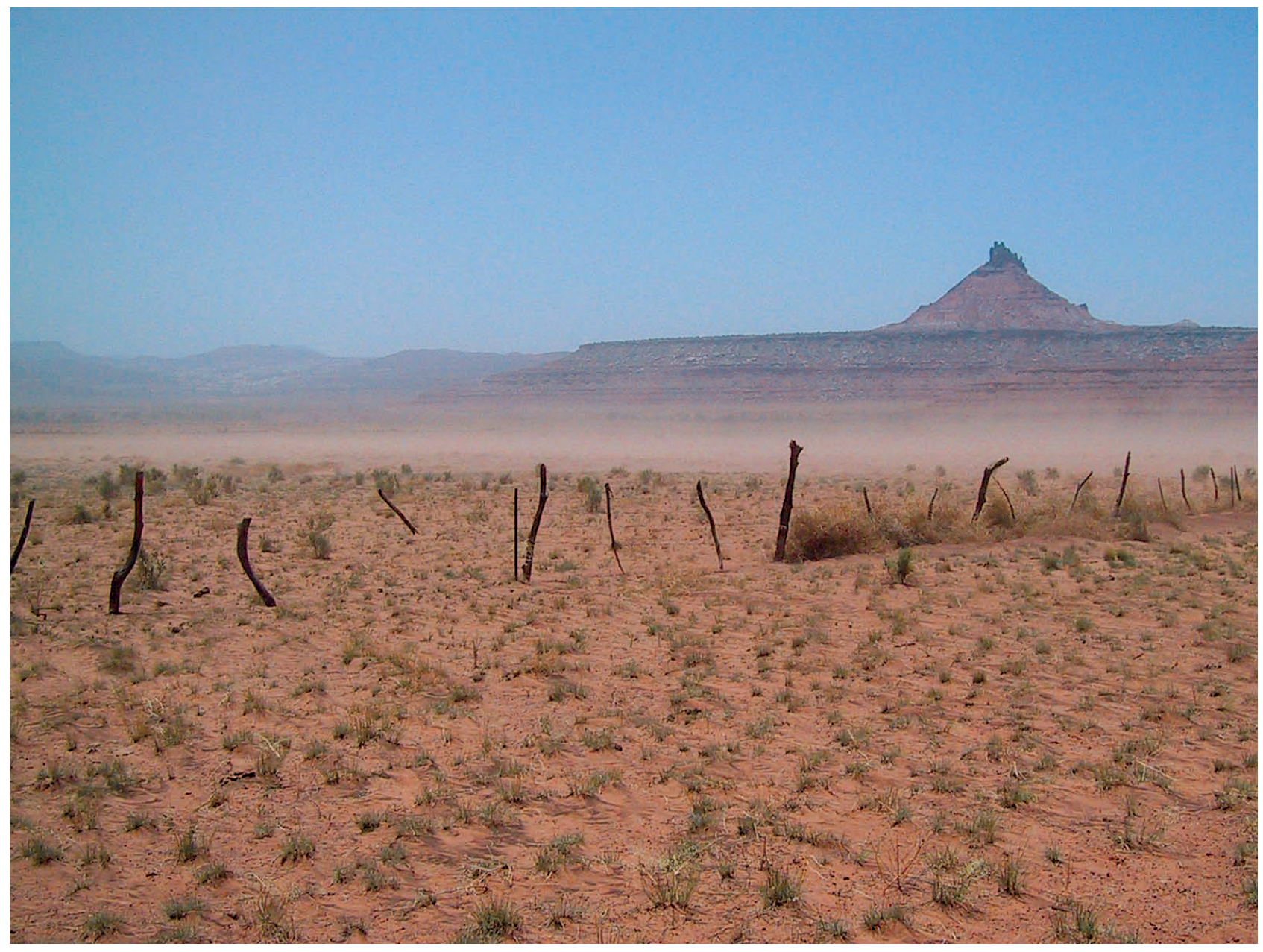

Wind-driven erosion of unstable soils. San Juan County, Utah. Photograph by Jason Neff, USGS.

dryland productivity, particularly during periods when water is abundant relative to evapotranspirational demands (Havstad and others, 2000; Archer and Bowman, 2002; Whitford, 2002; James and others, 2005). Water and nutrient uptake are not independent (Barber, 1995; Marschner, 1995), and Chapin (1991) has argued that the effects of low soil moisture on nutrient availability to plants may be as significant as the direct effects of water stress on plant performance. Following a review of fertilization experiments in dryland ecosystems, Hooper and Johnson (1999) concluded that there was no evidence for a shift from water to nutrient limitation along a geographic gradient of increasing water availability. Instead, their review supported the hypothesis that water and nitrogen (N) generally are co-limiting in dryland ecosystems. In addition to N, field studies on the Colorado Plateau suggest important roles for phosphorus (Miller and others, 2001; J.C. Neff, unpublished data, 2005) and potassium (Belnap and Phillips, 2001) in structuring dryland ecosystems of the region.

The retention of water and nutrient resources is essential for sustaining the structure and functioning of dryland ecosystems (Ludwig and Tongway, 1997, 2000; Whitford, 2002). Dynamic soil properties important for water and nutrient retention include soil structure, infiltration capacity, soilsurface roughness, organic-matter content, soil aggregate stability, and soil biotic activity (Herrick and others, 2002). Other ecosystem components that promote the capture and retention of soil resources include vegetation, biological soil crusts, and other soil-stabilizing features such as litter and rocks (Warren, 2003; Whitford, 2002).

\section{Plant-Soil Feedbacks}

Coupled spatial patterning of vegetation and soil resources is a common characteristic of dryland ecosystems because of strong interactions between plants and soils (Charley and West, 1975; Schlesinger and others, 1990, 1996). Vegetation affects the spatial distribution of soil resources because of processes such as nutrient uptake, above- and below-ground litter deposition, and microclimatic modification, as well as vegetation interactions with hydrologic processes and 


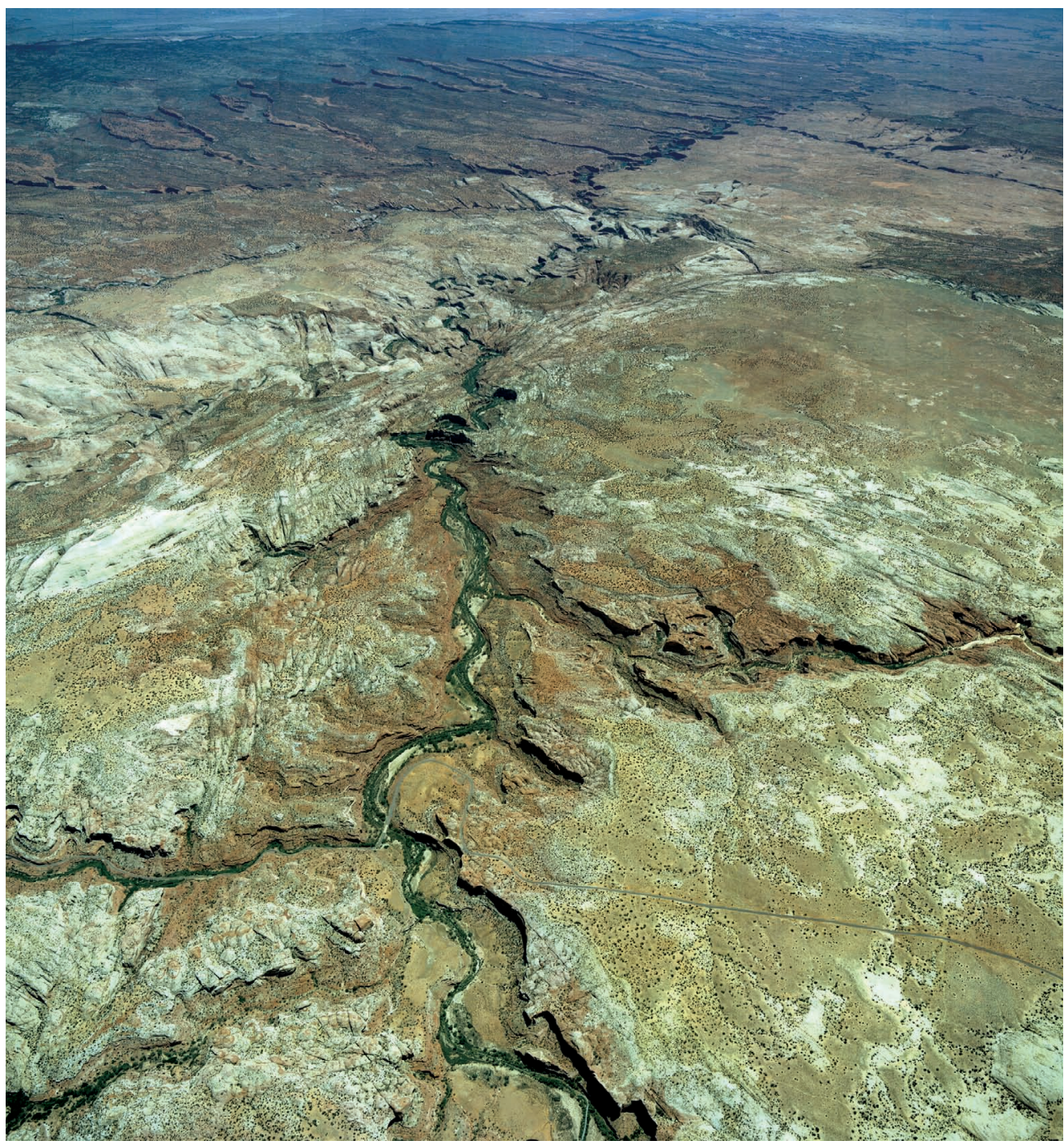

Oblique aerial photograph of the Escalante River drainage in Grand Staircase-Escalante National Monument showing heterogeneous patterns of soil and vegetation attributable to effects of geology, topography, and geomorphic processes. Garfield County, Utah. BLM aerial photograph.

water- and wind-driven erosional processes (Whitford, 2002). Vegetation patterns in turn are strongly influenced by spatial patterns of resource availability, resulting in a classic positive-feedback relationship (Aguiar and Sala, 1999). Because the spatial patterning of soil resources is so closely linked with several important biotic and abiotic processes, changes in resource distributions both within (canopy vs. interspace) and among ecosystems can indicate significant changes in ecosystem functioning (Ludwig and Tongway, 1997, 2000). Some workers have suggested that indices of soil-resource patterning may prove useful as early warning indicators of ecosystem degradation in dryland environments (Herrick and Whitford, 1995; Havstad and others, 2000).

\section{Major Functional Groups}

\section{Background}

Chapin and others (1996) identified biotic functional groups (hereafter described as functional types) as one of the four interactive controls of ecosystem sustainability because of the capacity of dominant functional types to shape the structure and functioning of whole ecosystems. Associated with efforts to model ecological consequences of global change, a vast literature has developed concerning different approaches to deriving or classifying functional types-particularly with respect to vegetation (for example, Smith and others, 1997). Identification and use of a particular functional-type scheme 
depend on the level or scale of analysis and on the function(s) of interest. For example, within a taxonomic group such as nematodes, different functional types may be identified on the basis of feeding preferences (Coleman and Crossley, 1996). The emphasis in this report is on broadly defined ecosystemlevel functional types. Several workers have proposed that the most important functions in dryland ecosystems are those that control the retention of water and nutrient resources because productivity and diversity cannot be sustained in systems that fail to retain resources (Ludwig and Tongway, 1997; Whisenant, 1999; Whitford, 2002). Functions affecting the cycling and retention of water and nutrient resources will be emphasized here, but other functions will not be excluded. For purposes of this report, it is less important to adopt a specific functional-type classification scheme than it is to take a broad functional perspective when considering the biotic components of dryland ecosystems.

Without adopting a particular classification scheme, it remains useful to identify two general categories of functional types that are equally important for ecosystem dynamics. These are (1) functional effect types - organisms with similar effects on ecosystem functions such as primary production, nutrient cycling, and soil stabilization, and (2) functional response types - organisms with similar responses to environmental factors such as climate, resource availability, natural disturbances, and land use activities (Walker, 1997; Walker and others, 1999; Díaz and Cabido, 2001; Díaz and others, 2002). The distinction between these two types is important for considering how biotic composition affects the resistance and resilience ${ }^{7}$ of ecosystems to climatic fluctuations and changes, natural disturbances, and anthropogenic stressors (Walker and others, 1999). Redundancy among organisms in terms of their effects on ecosystem processes, and diversity among organisms in terms of their responses to environmental factors, both can contribute to the buffering of ecosystem functioning in relation to changing environmental conditions (Díaz and Cabido, 2001). Although some workers have emphasized the importance of overall functional diversity for sustaining ecosystem processes (Tilman and others, 1997), the functional effect-response distinction suggests that the longterm persistence of ecosystem functioning may be most likely when different functional response types are nested within the same functional effect type (Walker and others, 1999; Díaz and Cabido, 2001). Detailed consideration of functional effect types and functional response types probably is most useful to ecosystem managers when applied on a relatively site- or system-specific basis. Because of the generality of this report,

\footnotetext{
${ }^{7}$ Resistance refers to the capacity of a particular ecosystem attribute or process to remain essentially unchanged from its reference state or dynamic despite exposure to a disturbance and/or stressor. Resilience refers to the capacity of a particular ecosystem attribute or process to recover to its former reference state or dynamic after exposure to a temporary disturbance and/or stressor (adapted from Grimm and Wissel, 1997). Resistance and resilience are dynamic properties that vary in relation to environmental conditions (Scheffer and others, 2001).
}

the functional effect-response distinction is not carried forth through the following discussion of biotic functional types.

\section{Vegetation}

Broadly speaking, vegetation generally is recognized as the dominant functional type in terrestrial ecosystems. In addition to conducting photosynthesis, above-ground structures of vascular plants protect soils from erosive raindrops, obstruct erosive wind and overland water flow, and enhance the capture and retention of soil resources. Litter from plants further reduces the erosive impacts of rainfall on soil surfaces and provides inputs to soil organic matter for soil stabilization and nutrient cycling. Plants and litter intercept solar radiation and precipitation, thereby mediating spatial and temporal patterns of soil water content and temperature (Breshears and others, 1997), and strongly affecting soil-resource conditions experienced by other organisms. Roots stabilize soils, are conduits for resource acquisition and redistribution, and provide organic-matter inputs to soil food webs. Vegetation also provides fuel for fire, as well as resources and habitat structure for below-ground and above-ground organisms ranging from fungi and bacteria to birds and large mammals (Whitford, 2002; Wardle, 2002). Finally, carbon storage and the mediation of earth-atmosphere energy/water balances are additional vegetation functions that are increasingly emphasized by researchers investigating global-change processes (Breshears and Allen, 2002; Asner and others, 2003).

A large number of vegetation attributes affects the manner and extent to which these many functions are performed. Size, biomass, photosynthetic rate, relative and absolute growth rates, tissue chemistry, basal cover, canopy cover, canopy structure, spatial arrangement and contiguity, leaf area, leaf longevity, and life span are some of the more important vegetation attributes for ecosystem functioning (Chapin, 1993). Root distribution, photosynthetic pathway, and phenology are additional functional attributes of vegetation that are particularly important in dryland ecosystems (Ehleringer and others, 1999; Whitford, 2002). With respect to disturbance interactions, important functional attributes include palatability, flammability, and mode of post-disturbance regeneration.

Small trees, shrubs, dwarf shrubs, and perennial grasses are the vegetative life forms with the greatest effects on the structure and functioning of dryland ecosystems (Whitford, 2002). In some dryland systems, annual grasses (typically exotic) also can have significant effects on ecosystem structure and function (for example, Billings, 1990; Belnap and Phillips, 2001; Evans and others, 2001). The two most important tree genera in drylands of this region are Juniperus and Pinus. Important genera of shrubs and dwarf shrubs include members of the Asteraceae (Artemisia, Chrysothamnus, Ericameria, Gutierrezia, Tetradymia, and Xylorhiza), the Chenopodiaceae (Atriplex, Grayia, Sarcobatus, and Krascheninnikovia), the Rosaceae (Cercocarpus, Purshia, Coleogyne, and Fallugia), the Fagaceae (Quercus), and the Ephedraceae (Ephe$d r a$ ). Important genera of perennial grasses include those 
characterized by the $\mathrm{C}_{4}$ photosynthetic pathway (Bouteloua, Muhlenbergia, Aristida, Pleuraphis, and Sporobolus) and the $\mathrm{C}_{3}$ photosynthetic pathway (Acnatherum, Hesperostipa, Poa, and Festuca). In general, the relative importance of $\mathrm{C}_{3}$ versus $\mathrm{C}_{4}$ perennial grasses in dryland ecosystems increases regionally with latitude and locally with elevation. Genera of annual grasses include Bromus, Festuca, and Schismus.

Many of the functional attributes described above differ greatly among vegetative life forms. ${ }^{8}$ For example, there are relatively large differences among dryland trees, shrubs, and perennial grasses in terms of canopy architecture and spatial arrangement, as well as in their responses to climate, fire, and herbivory. As a consequence, ecosystems characterized by different proportions and spatial patterns of trees, shrubs, and grasses can be expected to differ greatly in terms of associated ecosystem processes including nutrient cycles, hydrologic cycles, disturbance regimes, and wildlife-habitat relationships. Likewise, temporal shifts in the relative abundance and spatial configuration of vegetative life forms can significantly affect the functioning of numerous ecosystem processes.

\section{Soil Biota}

Soil biota represent another broadly defined group of organisms that is a major contributor to the structure and functioning of dryland ecosystems. Most of the ecosystem processes described above in relation to soil resources (that is, nutrient cycling, water infiltration and storage, soil aggregate stability) are mediated by soil organisms (Skujins, 1984; Whitford, 1996, 2002; Lavelle, 1997; Wardle, 2002). Although the general significance of soil biota for ecosystem processes (particularly nutrient cycling) has long been acknowledged, there is increasing recognition that this diverse group of organisms must be considered much more explicitly in order to develop a better understanding of the structure and functioning of terrestrial ecosystems (Bever and others, 1997; Wardle, 2002; Reynolds and others, 2003). Because of their intimate association with other components of dryland ecosystems, soil biota in figure 4 are included in components identified as soil resources, vegetation, biological soil crusts, and invertebrates.

Wardle (2002) noted that most terrestrial species occur in soil and that the tremendous (and poorly understood) diversity of this group has added to the logistical difficulties posed by studying below-ground organisms and processes. Soil biota include microfloral components (bacteria, algae, and fungi), microfaunal components (nematodes, microarthropods, and protozoans), and macrofaunal components (earthworms, ants, termites, and larval stages of several insect families) that are involved in a variety of processes essential for litter decomposition and nutrient cycling. Functioning of these below-ground processes is dependent on the amounts and types of organicmatter inputs from vegetation and on soil conditions such as moisture availability, soil structure, soil aeration, and soil

\footnotetext{
${ }^{8}$ There also is significant functional variation within each of these life forms that must be considered with respect to the structure and functioning of specific ecosystems on a site-specific basis.
}

temperature (Coleman and Crossley, 1996; Whitford, 1996, 2002; Wardle, 2002).

Soil biota also include mycorrhizal fungi that form symbiotic associations with roots of many plant species. The mycorrhizal symbiosis is one in which the fungal partner provides nutritional benefits to the host plant, and the plant provides carbohydrates to the fungi (Smith and Read, 1997). Roots colonized by mycorrhizal fungi acquire phosphorus, zinc, and possibly copper and $\mathrm{N}$ more efficiently than uncolonized roots. There is also evidence that mycorrhizae can increase water uptake in plants due to the greater soil volume accessed by colonized roots (Smith and Read, 1997). Due to their role in enhancing resource availability to colonized plants, mycorrhizae have been found to mediate competitive relations between plants with differing responses to mycorrhizal colonization (Allen and Allen, 1990; Marler and others, 1999). Recent work also has shown that the diversity of mycorrhizal fungi can determine the diversity and productivity of vascular plant communities (van der Heijden and others, 1998).

Some species in most of the plant families common to dryland ecosystems have been identified as mycorrhizal when inspected by botanists (Trappe, 1981). Families with a high frequency of mycorrhizal colonization among inspected species include the Asteraceae, Fabaceae, Rosaceae, Poaceae, and Solanaceae. Frequency of colonization among inspected species in the Chenopodiaceae and Cactaceae is much lower, although mycorrhizal species have been found. The Brassicaceae stands out as a common dryland plant family in which most inspected species are nonmycorrhizal (Trappe, 1981).

Another important symbiotic relationship involving soil biota is that between plants and $\mathrm{N}$-fixing bacteria. Several shrubs that are locally common or abundant throughout the Colorado Plateau region are capable of forming a symbiotic association with $\mathrm{N}$-fixing actinomycetes in the genus Frankia. Actinorhizal shrub genera of the region include Cercocarpus and Purshia (Rosaceae), Shepherdia (Elaeagnaceae), and Ceanothus (Rhamnaceae; Baker and Schwintzer, 1990; cited by Schwencke and Carú, 2001). The frequency of actual actinorhizal colonization in these genera and the overall contributions of this relationship to dryland $\mathrm{N}$ cycling are poorly understood. However, it is significant that all of the actinorhizal shrub genera in the region are important forage resources both for wild herbivores and for domestic livestock, suggesting that the actinorhizal relationship may be a factor affecting forage preferences.

\section{Biological Soil Crusts}

Biological soil crusts (BSCs) are biotic communities composed of cyanobacteria, algae, microfungi, mosses, and lichens that occur on and within the upper few millimeters of the soil surface (Belnap, Büdel, and Lange, 2003). These diverse communities are characteristic biotic components of ecosystems where environmental conditions limit the development of closed-canopy vascular plant communities or thick layers of surface litter (Belnap, Büdel, and Lange, 2003). They are particularly prominent features in drylands of the 


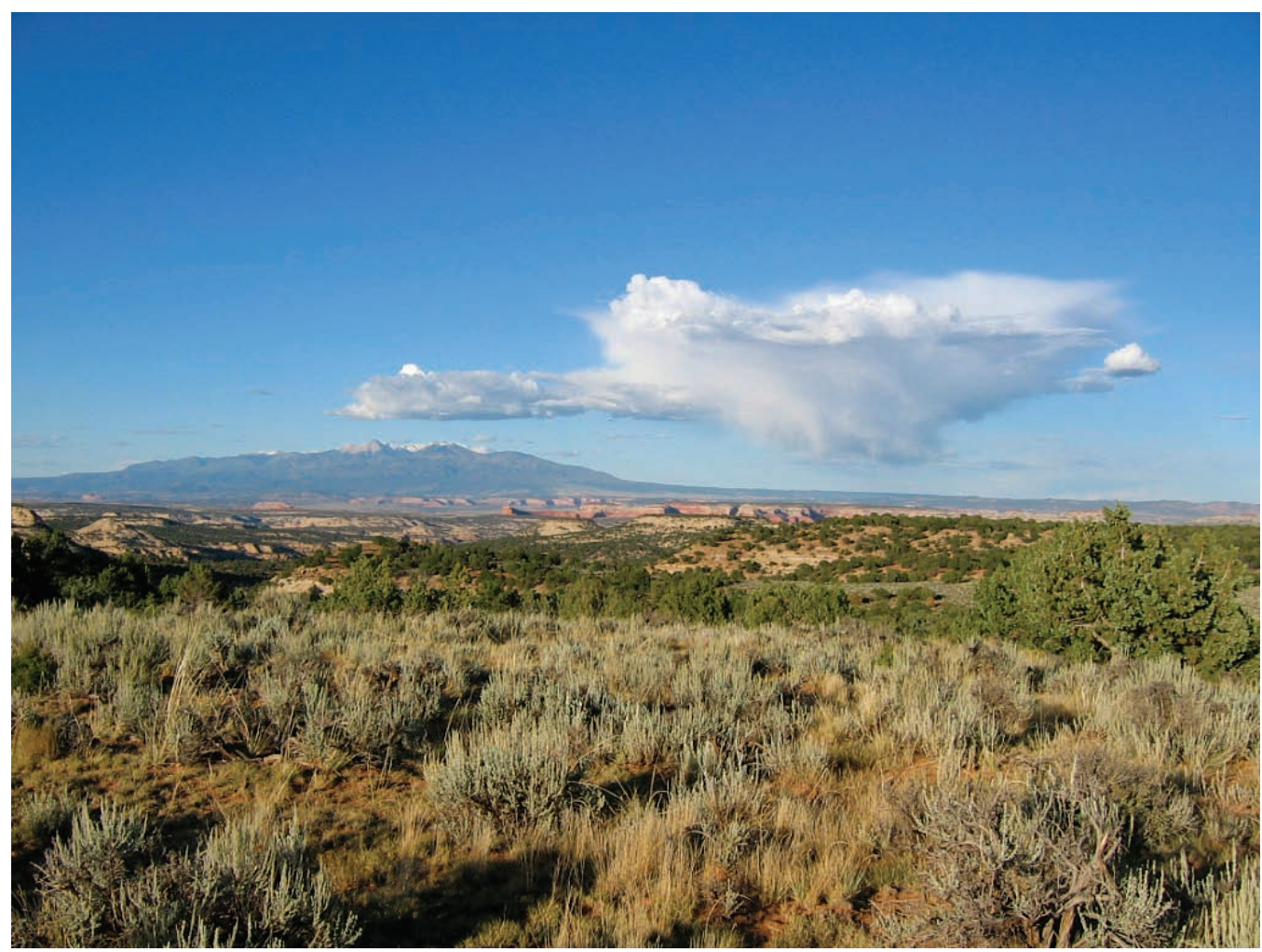

Colorado Plateau vegetation consisting of shrubs (Artemisia tridentata and Krascheninnikovia lanata), perennial grasses (Acnatherum hymenoides and Hesperostipa comata), and juniper (Juniperus osteosperma). The La Sal Mountains are in the background. San Juan County, Utah. Photograph by Mark Miller, USGS.

Colorado Plateau region where much pioneering work has been conducted concerning their environmental relationships, disturbance responses, and ecological functions (for example, Rosentreter and Belnap, 2003; Belnap, 2002; Bowker and others, 2002).

In addition to their major contributions to biological diversity, BSCs perform several functions in dryland ecosystems. The presence and physiological activity of BSC organisms aggregate soil particles, thereby increasing soil stability and reducing the susceptibility of soil to erosion by wind and water (Williams and others, 1995a,b). Surface characteristics and stability of BSCs also favor the capture and retention of aeolian sediments that can be significant sources of mineral nutrients in dryland ecosystems (Belnap, Prasse, and Harper, 2003; Reynolds and others, 2001). BSCs similarly can capture and enhance ecosystem retention of windborne and waterborne organic matter and seeds (Belnap, Prasse, and Harper, 2003).

Hydrologic effects of BSCs are complex, with few generalizations possible due to variations in relation both to soil factors and BSC factors. [The following synthesis is mostly drawn from the recent review by Warren (2003).] Aboveground structures of BSCs intercept rainfall, thereby reducing raindrop impact and erosivity and reducing the detachment of soil particles that can clog soil pores and inhibit infiltration. In this function, cyanobacteria and algae are less effective than mosses and lichens. Based on available evidence, BSCs on sandy soils ( $>80$ percent sand content) with inherently high infiltration capacities tend to reduce infiltration relative to soils of similar texture without BSCs because BSC organisms block pore spaces near the soil surface. However, adverse effects of BSCs on infiltration in sandy soils may be mitigated by effects of BSCs on soil-surface roughness. In cool-desert regions such as the Colorado Plateau, frost heaving can result in BSCs with pinnacled or rolling soil-surface microtopography (Belnap, 2003a). Where these microtopographic features significantly enhance soil-surface roughness, the velocity of overland flow may be reduced, thereby increasing the residence time of runoff on hillslopes, enhancing slope retention of water and waterborne sediment, and facilitating water infiltration (Belnap, 2003a).

On relatively fine-textured soils, BSC effects on hydrologic processes can differ from those found on sandy soilsalthough the soil-roughness hypothesis still applies (Warren, 2003). Compared with sandy soils, soils with a significant percentage of clay-size particles are characterized by lower porosity and lower inherent infiltration capacities. Organic carbon produced by BSC organisms can contribute to the formation of stable soil aggregates that increase the ratio of macropores to micropores and thus enhance infiltration. Due to enhanced soil aggregate stability, fine-textured soils with BSCs are likely to 


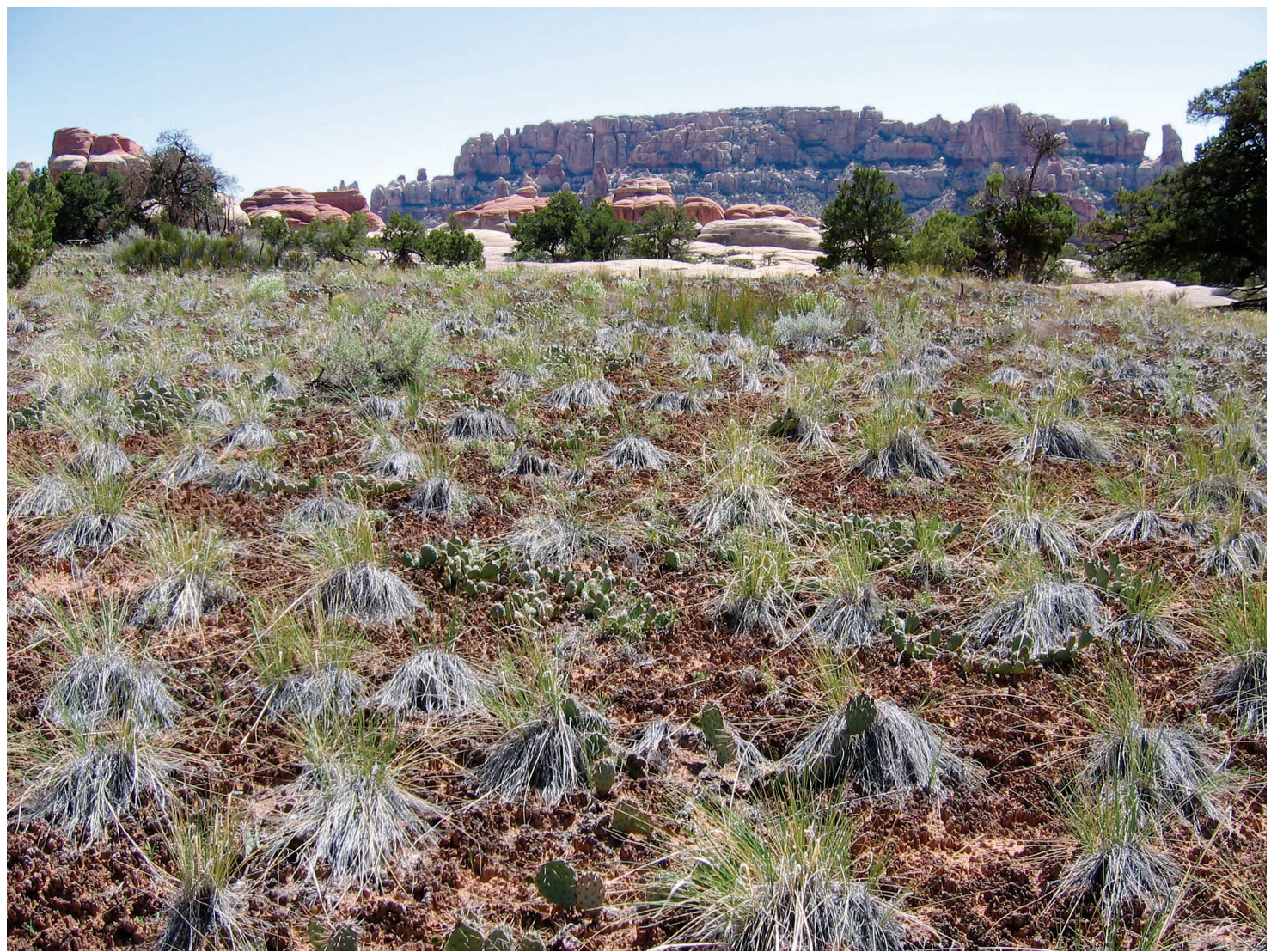

Biological soil crusts fill the interspaces among perennial grasses (Hesperostipa comata), shrubs (Atriplex canescens and Ephedra viridis) and cacti (Opuntia sp.) in Canyonlands National Park, San Juan County, Utah. Photograph by USGS.

have higher infiltration rates than soils of similar texture without BSCs. However, in silty soils where a vesicular A horizon ${ }^{9}$ subtends the BSC layer and controls soil infiltration capacity, the presence of BSC organisms is unlikely to enhance infiltration except through the hypothesized soil-roughness effect (for example, Dobrowolski, 1994).

In addition to enhancing soil stability and the retention of nutrients in sediment and organic matter, BSCs contribute to dryland nutrient cycles in other ways. Mosses, cyanobacteria, green algae, and lichens all are photosynthetic and thus are significant sources of carbon in dryland ecosystems, particularly in interspaces among vascular plants where soil crusts can attain 100 percent cover (Lange, 2003). Cyanobacteria (for example, Microcoleus, Nostoc, and Scytonema) and cyanolichens (for example, Collema and Peltigera) also are capable of fixing atmospheric $\mathrm{N}$ into a mineral form that can be used by vascular plants (Evans and Lange, 2003; Belnap, 2002). Although actinorhizal shrubs also are likely contribu-

\footnotetext{
${ }^{9}$ Vesicular A horizons as much as several $\mathrm{mm}$ thick are common at the surface of silty desert soils. Vesicular structure is characterized by a large volume of spherical soil voids that appear to form when soil air is entrapped in wetted soil. Presence of a vesicular horizon greatly reduces soil hydraulic conductivity (Hillel, 1998; Birkeland,1999).
}

tors to $\mathrm{N}$ cycles in the region (see above), the ubiquity of BSCs relative to actinorhizal shrubs suggests that BSCs are the major $\mathrm{N}$ contributors in the region (Evans and Ehleringer, 1993; Belnap, 2002). Soil-crust organisms are significant food sources for other soil biota, particularly enhancing the activity of soil food webs in interspaces among vascular plants (Belnap, 2003b). BSCs also affect the nutrient cycling activities of soil food webs through their effects on near-surface moisture availability, soil structure, soil aeration, and soil temperature (Belnap, 2003b).

BSCs influence vascular plants in a variety of ways. Effects of BSCs on soil-surface stability and roughness result in seed-bed characteristics that differ greatly from those of soils without BSCs. Seed catchment and retention are generally enhanced by the presence of BSCs. Belnap, Prasse, and Harper (2003) reviewed the literature concerning effects of BSCs on plant establishment and found that research results varied depending on BSC characteristics, the plant species investigated, methods of study, and environmental conditions. BSCs are best viewed as environmental sieves that favor or discourage plant establishment, depending on environmental conditions and on species-specific attributes such as propagule morphology and germination requirements. If a generalization 


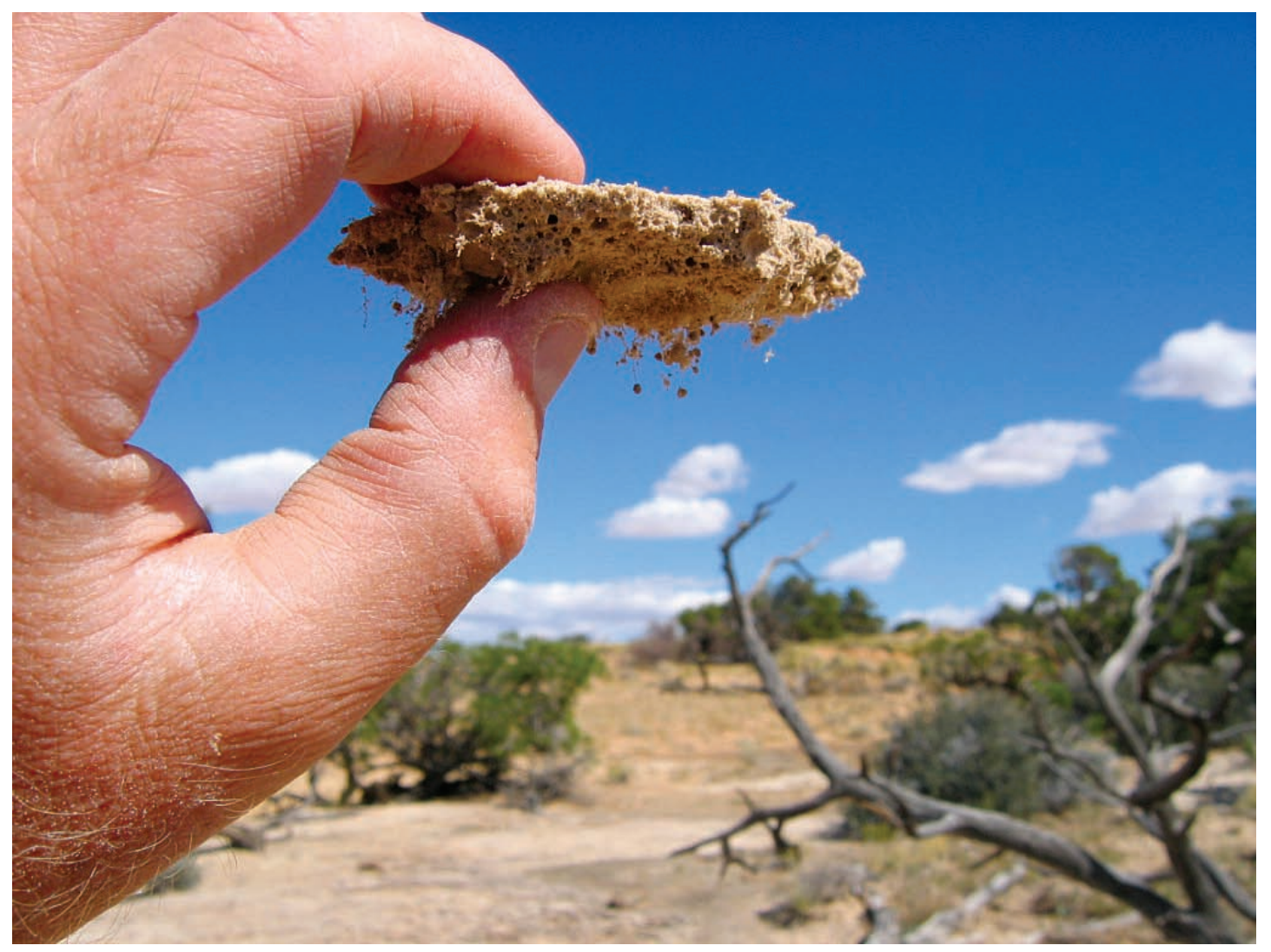

Grains of sand held by cyanobacterial filaments found in biological soil crusts. San Juan County, Utah. Photograph by Mark Miller, USGS.

is possible, it is that BSCs tend to inhibit establishment of annuals and species without specialized burial mechanisms such as twisting awns (Belnap, Prasse, and Harper, 2003). In southeastern Utah, Howell (1998) found that BSCs inhibited establishment of the exotic grass Bromus tectorum. Following the establishment phase, plants growing in soils with BSCs generally have been found to have greater biomass and lower root:shoot ratios than comparable plants growing in soils without BSCs, suggesting greater availability of soil resources in the presence of BSCs (Belnap, Prasse, and Harper, 2003). Relative to plants growing in soils without BSCs, plants growing in association with $\mathrm{N}$-fixing cyanobacteria and cyanolichens consistently have greater $\mathrm{N}$ concentrations in tissues and usually have higher concentrations of the plant-essential nutrients potassium, magnesium, copper, and zinc (Harper and Belnap, 2001). In contrast, plants growing in soils with BSCs commonly have lower concentrations of phosphorus and iron than plants growing in soils without BSCs, suggesting that plants and BSCs may compete for these elements. Nutritional differences between plants grown in soils with and without BSCs are greatest in shallow-rooted herbaceous species, probably because they are rooted in near-surface soils that are most directly influenced by BSCs (Harper and Belnap, 2001).

\section{Invertebrate and Vertebrate Consumers}

Vertebrate and invertebrate consumers are significant contributors to the biological diversity of dryland ecosystems in the region (for example, Nelson, 1994; Griswold and others, 1997; Hanna and Graham, 2003; San Miguel and Colyer, 2003). There are numerous ways in which above-ground consumers can directly or indirectly affect the structure and functioning of dryland ecosystems (Whitford, 2002). Activities associated with granivory and herbivory are among those that have the greatest ecosystem-level consequences because of their many effects on vegetation structure and soil processes. Processes of competition and predation likewise can have important ecosystem-level consequences by altering the structure of consumer food webs, but these processes are not reviewed here.

Granivory is one of the most-studied processes in dryland ecosystems, although most research on this topic has been conducted outside the region encompassed by this report. Organisms that can be important granivores in dryland ecosystems of the region include harvester ants, beetles, rodents, frugivorous mammals, and birds (Chambers and others, 1999; Whitford, 2002). Through selective harvesting, consumption, and dispersal via caching and defecation, granivores can have 
strong effects on the abundance, composition, and spatial distribution of the seed bank (Whitford, 2002). Through time, these seed-bank effects can be reflected in the composition and spatial structure of plant communities. For example, seed hoarding and caching behaviors of corvids such as Steller's jays (Cyanocitta stelleri) and Clark's nutcrackers (Nucifraga columbiana) have been implicated in the upslope migration of piñon in the Southwest (Chambers and others, 1999). In desert grasslands of southeastern Arizona, Brown and Heske (1990) proposed that selective seed harvesting and soil disturbance by kangaroo rats (Dipodomys sp.) were responsible for major changes observed in vegetation structure over a 12-year period. However, on the basis of subsequent studies, Whitford (2002) questioned whether the hypothesized mechanisms were sufficient to explain the observed vegetation changes. Whitford (2002) also suggested that effects of granivorous rodents and ants on soils (that is, resource enrichment through excretion and soil disturbance through burrowing) could have greater impacts on dryland vegetation structure than granivory itself.

Like granivory, herbivory can have numerous direct and indirect effects on ecosystem properties. Native herbivores in dryland ecosystems of the region include insects (grasshoppers, moth and butterfly larvae, bark beetles, and many others) and mammals such as woodrats (Neotoma spp.), desert cottontails (Sylvilagus audubonii), black-tailed jackrabbits (Lepus californicus), bighorn sheep (Ovis canadensis), pronghorn (Antilocapra americana), and mule deer (Odocoileus hemionus). In some locations, elk (Cervus elaphus) use of dryland systems also can be significant, particularly in winter (Allen, 1989). Herbivorous insects and small to medium-size mammals can have significant effects on vegetation structure and ecosystem processes such as nutrient cycling. With the exception of infrequent insect outbreaks (discussed below as a disturbance), the greatest ecosystem-level consequences of herbivory are those that can be caused by high densities of large-bodied browsers and grazers such as mule deer, elk, and domestic livestock.

Large herbivores can affect individual plants both directly and indirectly through a variety of mechanisms. Direct impacts include altered physiological function and morphology attributable to defoliation and trampling (Briske, 1991; Briske and Richards, 1995). Defoliation and trampling by large herbivores may indirectly influence plant performance as a consequence of altered microenvironmental conditions, soil properties (Thurow, 1991), mycorrhizal relations (Bethlenfalvay and Dakessian, 1984), competitive relations, and through effects on ecosystem processes such as nutrient cycling and hydrology. Seed dispersal is yet another indirect mechanism by which large herbivores and other animals may affect vegetation structure. Through time, combined direct and indirect impacts can result in altered plant population dynamics (for example, altered rates of reproduction, recruitment, and mortality) and consequent changes in plant community composition, structure, and distribution (Crawley, 1983; Archer and Smeins, 1991; Archer, 1994; Miller and others, 1994; Bich and others, 1995). Because of strong interactions of vegetation with nutrient cycling, hydrologic processes, disturbance regimes, and geomorphic processes, herbivore-driven changes in vegetation structure can have cascading effects on multiple ecosystem processes and properties.

Considerable debate has occurred concerning the consequences of herbivory for plant productivity (for example, McNaughton, 1983, 1986, 1993; Belsky, 1986, 1987; Painter and Belsky, 1993; Dyer and others, 1993). This debate has centered on the phenomenon of "compensatory growth" in defoliated plants. Compensatory growth generally is defined as a positive response of plants to injury by defoliation (Belsky, 1986). McNaughton (1983, p. 329) described the phenomenon as follows:

"Compensatory growth in plants subjected to herbivory may alleviate the potential deleterious effects of tissue damage, whether to vegetative or reproductive organs. Tissue destruction is rarely, if ever, translated monotonically into a proportional reduction of final yield. Internal mechanisms of compensation involve modifications of plant metabolism; external mechanisms of compensation involve modifications of the plant environment that are favorable to plant growth and yield."

Belsky (1986) clarified the discussion by subdividing the term "compensation" into three separate terms defined by the productivity of a defoliated plant in relation to that of an undefoliated plant (see table 2).

Numerous physiological (internal) and/or microenvironmental (external) mechanisms may contribute to the occurrence of compensatory growth in plants (Crawley, 1997). For example, remaining foliage may experience increased relative growth rates due to diminished shading and increased light levels following grazing (a microenvironmental mechanism), or remaining foliage of a grazed plant may experience greater above-ground growth due to the reallocation of resources from root growth (a physiological mechanism). In general, the potential for and significance of compensatory growth is believed to vary in relation to the timing of herbivory in relation to plant phenology, the frequency and intensity of herbivory, the availability of resources both within the plant and in the surrounding soil environment (water and mineral nutrients), as well as the presence and competitive ability of neighboring plants (Briske and Richards, 1994, 1995; Crawley, 1997). Given the importance of resource availability for the occurrence and significance of compensatory growth, DeAngelis and Huston (1993) and Bartolome (1993) reasoned that overcompensation was most likely to occur in productive, intensively managed systems rather than in resource-poor environments characteristic of dryland ecosystems. In a review concerning the physiological responses of plants to grazing, Briske and Richards (1994, p. 169) concluded that (1) compensatory mechanisms only infrequently increase the total growth of defoliated plants above that of undefoliated plants (that is, "overcompensation" is rare), and (2) application of the concept to management of wildland vegetation is unwarranted because the phenomenon is so complex and poorly understood. 
Table 2. Compensatory growth of plants in response to tissue removal (modified from Belsky 1986).

\begin{tabular}{|c|c|c|}
\hline $\begin{array}{c}\text { Possible Plant } \\
\text { Responses to Defoliation }\end{array}$ & $\begin{array}{c}\text { Productivity of Defoliated Plant in Relation } \\
\text { to that of Undefoliated Plant }\end{array}$ & Growth Compensation (\%) \\
\hline 1. Overcompensation & Defoliated > Undefoliated & 100 \\
\hline 2. Exact compensation & Defoliated = Undefoliated & $<100$ \\
\hline 3. Undercompensation & Defoliated < Undefoliated & 0 \\
\hline a. Partial compensation & Defoliated < Undefoliated & $<0$ \\
\hline b. No compensation & Defoliated < Undefoliated & $<0$ \\
\hline c. Damage & Defoliated < Undefoliated & \\
\hline
\end{tabular}

Although compensatory growth of individual plants may occur, alteration of competitive relations among defoliated or differentially defoliated plants is of greater consequence for plant populations and communities (Briske, 1991; Archer and Smeins, 1991; Briske and Richards, 1994; Crawley, 1997). Plants that possess a greater capacity for regrowth following defoliation experience a competitive advantage over defoliated competitors that possess a lesser capacity for regrowth. Similarly, plants that are defoliated less frequently or less intensively experience a competitive advantage relative to plants that are defoliated more frequently or more intensively due to relative differences in accessibility or palatability. For an individual plant, the most significant benefit arising from herbivory is the relative advantage gained when a neighboring plant has been reduced in size and competitive ability by an herbivore (for example, Caldwell and others, 1987). Through time, altered competitive relations eventually can be expressed in population dynamics and plant community structure (Briske, 1991).

Large herbivores also can affect the productivity and composition of plant communities through numerous indirect and direct effects on nutrient cycling (Archer and Smeins, 1991). Herbivore-driven shifts in plant community structure can affect nutrient cycles by altering the capacity of vegetation to capture and retain soil and water resources (Whitford, 2002) and by altering the quantity and quality of organic-matter inputs (Bardgett and Wardle, 2003; Reeder and others, 2004). Herbivory removes foliage and directly diverts nutrients from litter and physiological processes of intra-plant cycling. Nutrients acquired from foliage may be incorporated in animal biomass or spatially redistributed across the landscape in urine and dung. Where excreta are deposited, productivity may be enhanced if nutrients contained in the excreta are accessible to nearby plants. In other portions of the landscape, productivity may be reduced due to the removal of nutrients in foliage.

Significant losses of nutrients from ecosystems may occur as a consequence of herbivory (Archer and Smeins, 1991; West 1991). A significant proportion of the $\mathrm{N}$ consumed in foliage is lost to the atmosphere in gaseous products of digestion and through volatilization of ammonia from dung and urine. In ecosystems where dung beetles are not present to bury feces and cycle nutrients through soil food webs (including much of the Colorado Plateau region), as much as 80 percent of fecal $\mathrm{N}$ may be lost to volatilization, with greatest losses expected from sandy, high-pH soils (Woodmansee, 1979). Schimel and others (1986) found lower rates of $N$ loss from cattle urine, possibly because urine enters the soil more readily than dung. These researchers reported higher $\mathrm{N}$ losses from cattle urine in coarse soils (12-27 percent) than from fine-textured soils ( $0-2$ percent). Nutrients incorporated in animal biomass are removed from the ecosystem entirely when livestock are removed.

In dryland ecosystems where components of biological soil crusts are the predominant sources of $\mathrm{N}$ inputs, trampling by large herbivores also can have direct effects on nutrient cycling. Evans and Ehleringer (1993) found that N-fixing cyanobacteria and cyanolichens in biological soil crusts were the primary sources of $\mathrm{N}$ inputs to a piñon-juniper ecosystem in southern Utah. They hypothesized that trampling disturbance of biological soil crusts could eventually result in long-term ecosystem degradation due to diminished $\mathrm{N}$ inputs by damaged or eliminated N-fixing crust organisms. In southeastern Utah (Canyonlands NP), Evans and Belnap (1999) compared soil $\mathrm{N}$ dynamics between an ungrazed grassland and an adjacent grassland that experienced intermittent winter grazing by livestock prior to 30 years ago. Cover of N-fixing cyanolichens was 5.5 percent in the ungrazed grassland and less than 1 percent in the formerly grazed grassland. Compared with the formerly grazed grassland, the ungrazed grassland was characterized by soil-crust $\mathrm{N}$ fixation rates that were 2.5 times greater and soil $\mathrm{N}$ content that was $1.35-2.5$ times greater. The authors concluded that soil disturbance had resulted in longterm consequences for $\mathrm{N}$ cycling and storage in the dryland ecosystem they studied. Thus, although some plants may benefit from localized resource enrichment attributable to herbivore excreta, the literature suggests that the long-term consequence of herbivory and trampling by large ungulates in dryland ecosystems could be a gradual ecosystem-level decline in $\mathrm{N}$ 


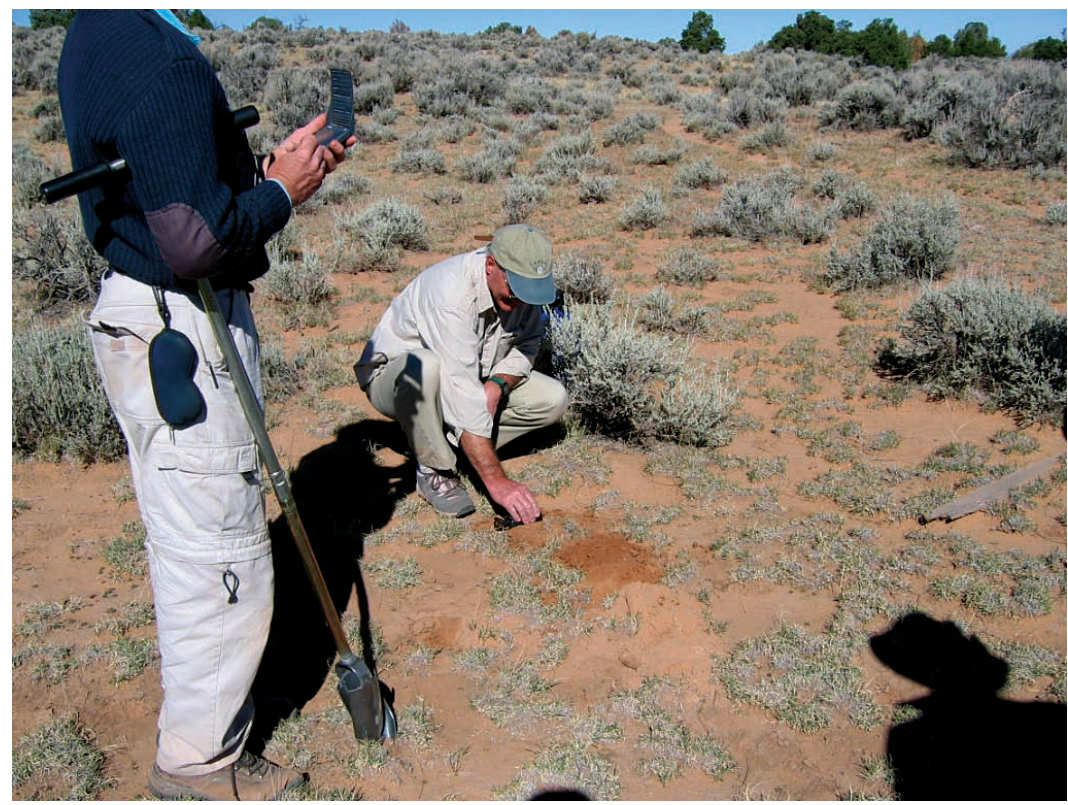

USGS geologist measuring soil magnetic properties to support studies relating vegetation patterns to geomorphic processes affected by climate and land use. San Juan County, Utah. Photograph by Mark Miller, USGS.

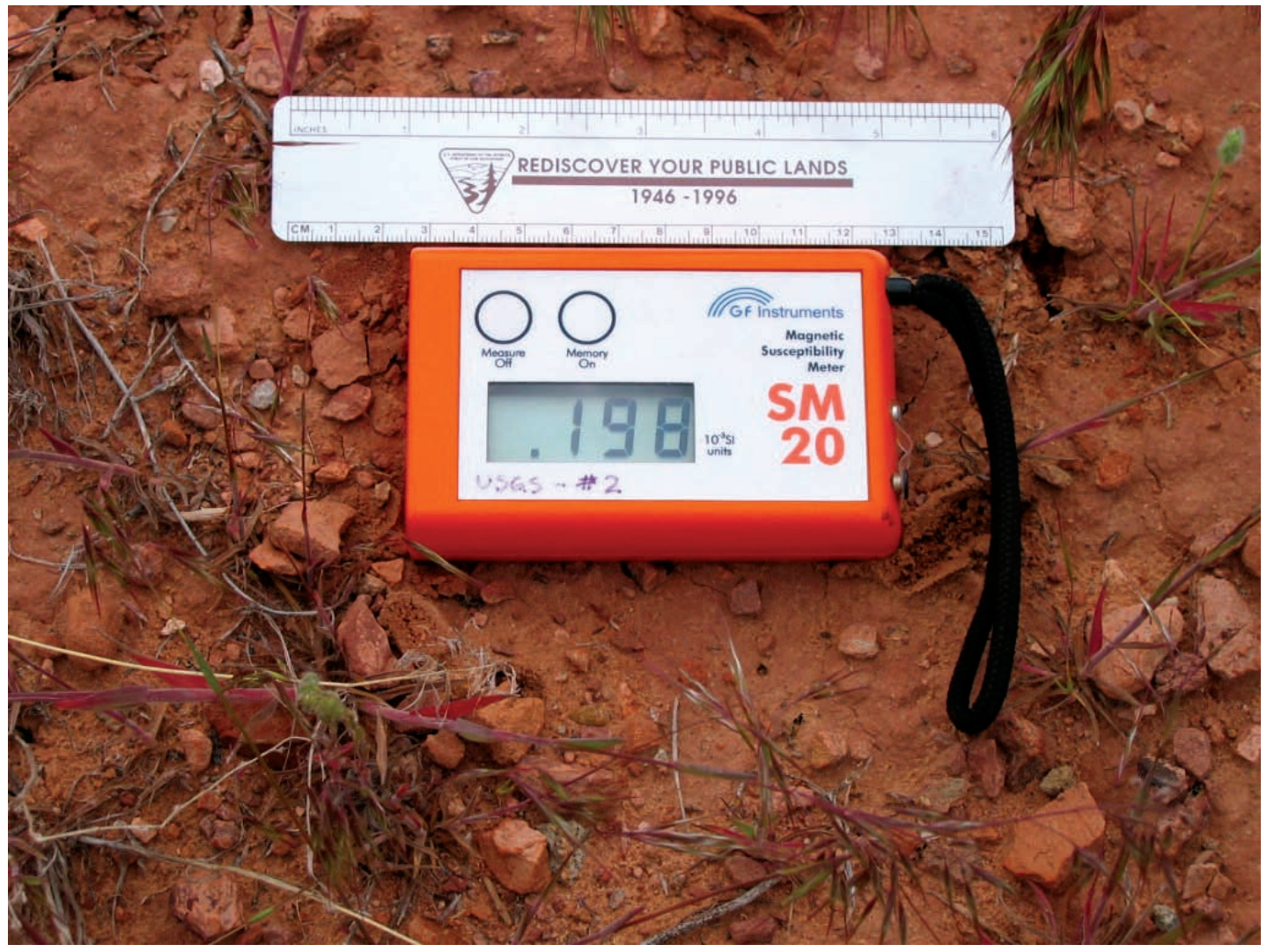

Magnetic susceptibility meter used for measuring magnetic properties of soils and rocks. San Juan County, Utah. Photograph by Mark Miller, USGS. 


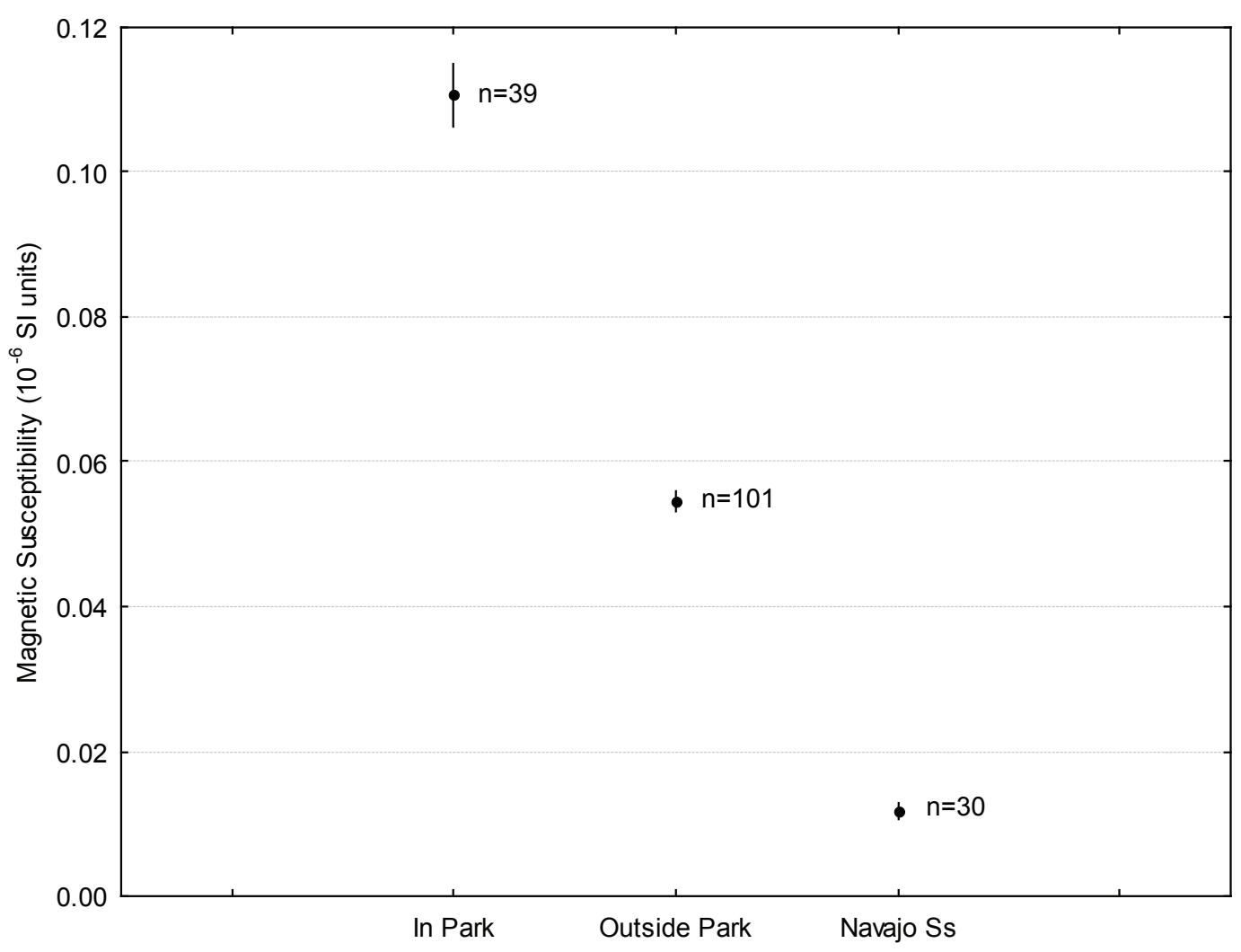

Figure 7. Magnetic susceptibility (mean $\pm 1 \mathrm{SE}$ ) of surficial sediments at a formerly grazed grassland site in the Island in the Sky District of Canyonlands National Park (ungrazed for 30 years), a currently grazed grassland site outside the Park, and of Navajo Sandstone bedrock - the principal parent material for soils at both sites. Surface soils at both sites are classified as Begay fine sandy loams (coarse-loamy, mixed, mesic Ustollic Camborthid). The higher magnetic susceptibility value for soils at the formerly grazed site indicates greater soil content of dust-borne magnetite, clay- and silt-size soil particles, and rock-derived mineral nutrients relative to soils at the currently grazed site outside of the park, thus suggesting loss of accumulated nutrients at the grazed site. The value for Navajo Sandstone indicates a baseline measure of surficial sediments without aeolian magnetite.

fertility. Following a review of mechanisms by which aboveground and below-ground herbivores affect nutrient cycling, Bardgett and Wardle (2003) concluded that positive effects of herbivory on soil processes and soil biota are most common in ecosystems with high soil fertility and relatively high consumption rates, whereas adverse effects are most common in low-fertility ecosystems with relatively low consumption rates.

In addition to impacts of trampling on $\mathrm{N}$ inputs where biological soil crusts are present, repeated trampling by large herbivores can destabilize soils and result in the depletion of rock-derived nutrients through the aeolian loss of fine soil particles. For example, Neff and others (2005) found lower contents of fine soil particles and rock-derived nutrients at two formerly grazed sites relative to an ungrazed site at the Needles District of Canyonlands NP. On the basis of soil magnetic properties which indicate the presence of far-traveled aeolian dust in these sandstone-derived soils, the authors attributed soil differences between the ungrazed and grazed sites to accelerated wind erosion caused by destabilizing effects of repeated trampling at the grazed sites. Because of the strong positive relationship between soil magnetic susceptibility and several lab-based measures pertaining to the bioavailability of rock-derived nutrients in sandstone-derived soils (for example, cation exchange capacity, silt content, phosphorus and potassium bioavailability), magnetic susceptibility shows promise as an indicator of long-term soil-surface stability in some Colorado Plateau landscapes (for example, fig. 7).

Some workers have hypothesized that trampling by large herbivores has beneficial impacts on infiltration (Savory and Parsons, 1980; Savory, 1988). However, an extensive amount of hydrologic research has failed to support this hypothesis (Spaeth and others, 1996; Holechek and others, 2000), indicating instead that trampling tends to result in lower infiltration rates where it destroys stable 
soil aggregates and leads to a deterioration of soil structure (Thurow, 1991). Hydrologic impacts of trampling by large herbivores vary in relation to soil type (for example, texture and the presence of a vesicular A horizon), soil water content, seasonal climatic conditions, vegetation type, and the magnitude of trampling (Thurow, 1991).

\section{Natural Disturbance Regimes}

\section{Background}

A disturbance is "...any relatively discrete event in time that disrupts ecosystem, community, or population structure and changes resources, substrate availability, or the physical environment" (White and Pickett, 1985, p. 7). For purposes of ecosystem management and monitoring, disturbances are considered to be ecological factors that are within the range of conditions naturally experienced by the ecosystem (for example, drought). These are differentiated from stressors, which may fit the definition of disturbance but are outside the range of disturbances naturally experienced by the ecosystem and typically are anthropogenic in origin (Whitford, 2002). Implicit in the "natural" aspect of these definitions is the need to identify ecosystem-specific reference conditions which are framed with respect to a particular time period and place (White and Walker, 1997; Landres and others, 1999). In addition to these temporal and spatial bounds, ecosystem managers should explicitly identify associated goals, assumptions, and value judgments when adopting a particular set of reference conditions as the "natural" standard for management and monitoring (Truett, 1996; Landres and others, 1999). Late-Holocene, pre-European conditions often are identified as the standard for defining natural disturbance regimes, although it is important to recognize the potentially important role of pre-European human populations in shaping disturbance regimes and ecosystem conditions found at the time of European contact (Betancourt and Van Devender, 1981; White and others, 1999).

In addition to climatic fluctuations, disturbances are major drivers of ecosystem change and variability. Disturbance is a factor affecting the spatial and temporal dynamics of all ecosystems, but disturbances differ greatly among ecosystems in relation to climate, topography, substrate, and ecosystem attributes such as vegetation structure. Disturbances can be differentiated on the basis of several descriptors which, taken in combination, characterize the disturbance regime. Descriptors of disturbance regimes include the kind of disturbance (for example, surface fire versus windthrow), spatial characteristics (for example, patch size, spatial extent and patterning), temporal characteristics (for example, frequency, timing, return interval), specificity (for example, selective effects by species, age class, or landscape unit), magnitude (for example, intensity, severity), and synergisms (for example, interactions with other disturbances ; Sousa, 1984; White and Pickett, 1985; White and others, 1999). Most ecosystems experience more than one type of disturbance, and interactions among disturbances commonly occur because particular disturbance events can affect the capacity of ecosystem components or processes to resist or recover from subsequent disturbances. Similarly, interactions can occur between natural disturbances and anthropogenic stressors (White and others, 1999; Archer and Stokes, 2000). Because disturbances play such an important role in shaping the structure and functioning of ecosystems (strongly interacting with soil resources and vegetation structure), disturbanceregime alteration is one of the most common ways by which human activities affect the functioning and sustainability of ecosystems (Chapin and others, 1996).

\section{Extreme Climatic Events}

Episodic severe climatic events are major disturbances in dryland ecosystems (Walker, 1993; Whitford, 2002). Drought, extreme precipitation events and floods, and wind storms can induce long-term changes in ecosystem structure and function by causing widespread mortality or enabling establishment of long-lived plants that are structural dominants. The erosive energy of extreme precipitation and wind events also can result in massive transport and redistribution of soil resources, potentially inducing geomorphic changes that fundamentally alter site conditions. Event sequencing (for example, timing of flooding in relation to drought) is an important factor that can affect ecosystem resistance and resilience to episodic climatic events. Although episodic, event-driven change is an important feature of many ecosystems (Holling, 1996; Scheffer and others, 2001), it is particularly characteristic of dryland ecosystems (Whitford, 2002). Examples from this region include the 1950's drought that affected the structure of piñon-juniper woodlands throughout much of the Southwest (Betancourt and others, 1993; Allen and Breshears, 1998), as well as the recent severe drought (the "early $21^{\text {st }}$ century drought" of Webb and others, 2004) that has caused region-wide mortality in piñon (USDA Forest Service, 2003) and sagebrush (Artemisia spp.). Climatic conditions and events can affect ecosystem susceptibility to other disturbances such as fire and insect outbreaks (Swetnam and Betancourt, 1998), as well as affect ecosystem resistance and resilience to anthropogenic stressors (Archer and Stokes, 2000; Scheffer and others, 2001).

Fire

Fire is another type of natural disturbance that can have many direct and indirect effects on the structure and functioning of dryland ecosystems. One of the most significant direct effects of fire is the alteration of vegetation composition and structure due to the selective damaging or elimination of fire-intolerant life forms or age classes (Whelan, 1995). Specific effects of fire on vegetation structure vary in relation to fire-regime characteristics (for example, frequency, intensity, seasonality, and spatial patterning) and fire responses of dominant vegetative life forms. Fire-regime characteristics are strongly influenced by the vegetation itself, as well as by preceding and coincident weather conditions that affect fuel availability, fuel flammability, and fire behavior. In some 


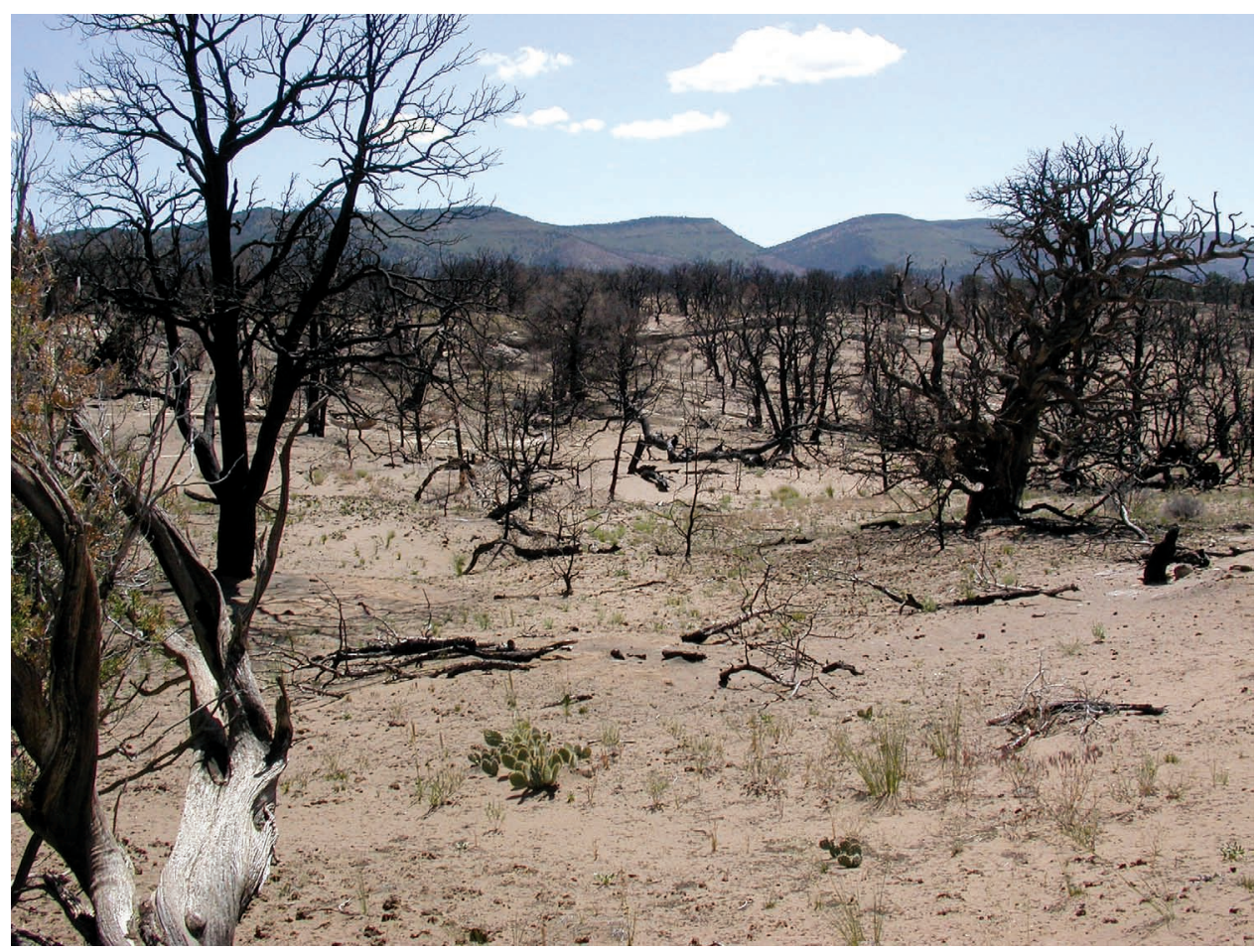

Soils susceptible to erosion following fire in a piñon-juniper woodland, Dinosaur National Monument, Moffat County, Colorado. Photograph by Mark Miller, USGS.

dryland ecosystems, low-intensity surface fires play a role in thinning or eliminating fire-intolerant woody vegetation and favoring the relative dominance of relatively fire-tolerant graminoids (Jameson, 1962; Wright, 1980). In systems where repeated surface fires are required to maintain grassland- or savanna-like physiognomic structure, the necessary fire frequency depends on the amount of time needed for predominant woody taxa to (1) develop features that confer resistance to surface fires (for example, thick bark and elevated canopies) or (2) competitively exclude herbaceous taxa that provide fine fuels to support surface fires. Most effects of fire on wildlife also are mediated through effects on vegetation structure and nutritional quality of forage (Smith, 2000).

Effects of fire on vegetation structure have multiple ecosystem-level consequences because of strong vegetation interactions with soil, hydrology, and geomorphic processes. Fire-caused reductions in ground cover and vegetation structure can result in significant erosional losses of soils, nutrients, and organic matter by water and wind (Johansen and others, 2001; Whicker and others, 2002). Soil hydrophobicity caused by fire is another factor which can result in accelerated waterdriven erosion because of decreased infiltration and increased runoff (Johansen and others, 2001; MacDonald and Huffman, 2004). In a study conducted in burned and unburned Chihuahuan desert shrublands, Whicker and others (2002) found that aeolian soil movement measured by passive soil collectors was 70 times greater at the burned site relative to the unburned site during high-velocity wind events shortly after fire occurrence and was 3 times greater over the entire 8-month study period.

Fire also has significant ecosystem-level consequences due to effects on nutrient cycles (Raison, 1979; Blank and others, 1994a, b). Depending on the type and intensity of fire events, fire can (1) increase nutrient bioavailability on a shortterm basis due to ash deposition and accelerated rates of nutrient cycling, and (2) deplete total nutrient stocks due to gaseous losses (particularly N) and off-site transfers of ash (Raison, 1979). Nutrient losses in gases and ash are generally proportional to heat generated and organic-matter consumed by fire (Raison, 1979; Schlesinger, 1997). Depending on fire severity, other soil characteristics can be affected by fire, including pH (typically increased by ash deposition), cation exchange capacity and infiltration capacity (both typically decreased by organic-matter losses and transformations; Raison, 1979), and erodibility (Whicker and others, 2002).

Natural fire regimes vary greatly among dryland ecosystems of the Colorado Plateau region. Fire generally is insignificant as a natural disturbance in sparse desert shrublands dominated by taxa such as Atriplex confertifolia, A. corrugata, Coleogyne ramosissima, and Sarcobatus vermiculatus, as well as in semidesert grasslands dominated by taxa such as Acnatherum hymenoides, Hesperostipa comata, Aristida spp., Sporobolus spp., and Pleuraphis jamesii. These grasslands have been described as "galleta-three-awn shrub steppe" (Küchler, 1964; West and Young, 2000) and are characteristic 


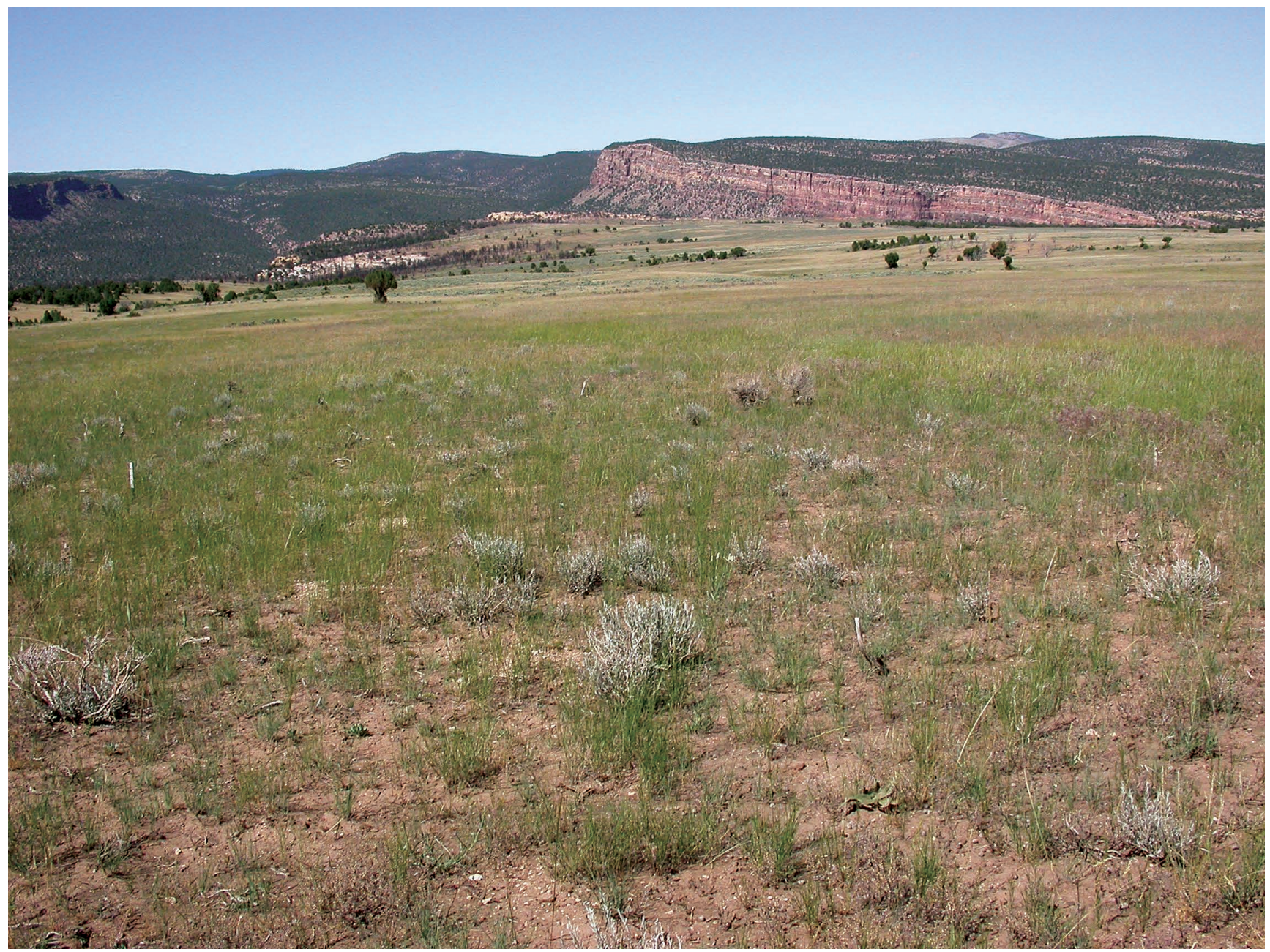

Prior to a prescribed fire conducted by NPS resource managers, vegetation on Iron Springs Bench in Dinosaur National Monument was dominated by Wyoming big sagebrush (Artemisia tridentata ssp. wyomingensis). Post-fire vegetation is dominated by native grasses including western wheatgrass (Pascopyrum smithii), bluebunch wheatgrass (Pseudoroegneria spicata), muttongrass (Poa fendleriana), and needle-and-thread grass (Hesperostipa comata). Dinosaur National Monument, Moffat County, Colorado. Photograph by Mark Miller, USGS.

of Canyonlands NP, Capitol Reef NP, Arches NP, Glen Canyon NRA, and Chaco Culture National Historic Park.

In contrast to these fuel-limited systems where fire is of minimal importance, fire is a significant natural disturbance in several other dryland ecosystems of the region. These include sagebrush shrublands and shrub steppe (for example, Dinosaur NM, Fossil Butte NM, and Black Canyon of the Gunnison $\mathrm{NP}$ ), relatively productive semidesert grasslands and juniper savannas (for example, Wupatki NM; Jameson, 1962; Johnsen, 1962), and piñon-juniper woodlands and forests (for example, Mesa Verde NP and Zion NP). Miller and others (1994) estimated that natural fire-return intervals in sagebrush steppe varied from 20-30 years in mountain big sagebrush systems (Artemisia tridentata ssp. vaseyana) to 50-100 years in Wyoming big sagebrush systems (A. tridentata ssp. wyomingensis) prior to the introduction of livestock and effective fire suppression. However, caution is warranted regarding generalizing from these estimates since they were derived from observations made in Great Basin ecosystems rather than Colorado Plateau ecosystems. Fire-history studies in sagebrush systems also are hampered by the absence of plant species that record fires by means of datable scars.

Natural fire regimes in ecosystems vegetated by various species of piñon and juniper are poorly understood. Contributing factors include the tremendous structural and functional diversity of systems broadly categorized as piñon-juniper vegetation types (for example, Harper and others, 2003) and the relative lack of area-specific fire-regime studies conducted in such systems across the region (Baker and Shinneman, 2004). In a systematic review of the natural role of fire in piñonjuniper ecosystems, Baker and Shinneman (2004) concluded that (1) spreading, low-severity surface fires probably were 
uncommon in such ecosystems prior to EuroAmerican settlement, and (2) much additional area-specific research is urgently needed to provide a foundation for science-based management and restoration efforts. In this latter conclusion, they are in agreement with other workers who have warned ecosystem managers not to rely uncritically on fire-regime generalizations derived from studies conducted elsewhere (for example, Veblen, 2003; Romme, Floyd-Hanna, and Hanna, 2003).

Some of the most extensive work on piñon-juniper fire regimes on the Colorado Plateau has been conducted at Mesa Verde NP. Floyd and others $(2000,2004)$ recently estimated that the natural fire rotation time (amount of time required to burn an area equal in size to the entire area under consideration) in piñon-juniper ecosystems at Mesa Verde NP is approximately 400 years (Floyd and others, 2000, 2004; Floyd, Romme, and Hanna, 2003; Romme, Floyd-Hanna, and Hanna, 2003). No fire scars indicative of surface-fire occurrence have been located at Mesa Verde NP despite extensive searching. Instead, minimum stand ages ranging from 200 to over 400 years indicate that the natural piñon-juniper fire regime at Mesa Verde NP is one characterized by infrequent, stand-replacing canopy fires. In a study conducted on the Uncompahgre Plateau north of Mesa Verde NP, Eisenhart (2004) also concluded that (1) there was no evidence to support the idea that frequent, low-severity surface fires were common in any piñon-juniper ecosystems in her study area, and (2) the predominant natural disturbance regime in these ecosystems is infrequent, stand-replacing canopy fires.

In an attempt to clarify issues associated with piñonjuniper fire regimes, Romme, Floyd-Hanna, and Hanna (2003) proposed a framework describing a set of hypotheses concerning variations in piñon-juniper structure, function, and status (see table 3 on p. 41). They identified three types of piñon-juniper systems that are fundamentally different in these respects. Of the three types, the authors hypothesized that only the piñon-juniper grass savanna is characterized by a natural fire regime consisting of frequent, low-severity surface fires (table 3). Grasslands and juniper savannas found in and around Wupatki NM exemplify this type of system (Jameson, 1962; Johnsen, 1962), as did significant proportions of the landscape at Bandelier NM prior to the introduction of livestock in the $19^{\text {th }}$ century (Allen, 1989). The piñon-juniper shrub woodland is a vegetation type with a natural disturbance regime that involves moderately frequent stand-replacing fire carried by shrub and tree canopies (table 3; Romme, Floyd-Hanna, and Hanna, 2003). The authors hypothesize that the natural post-fire successional sequence in this type proceeds from herb dominance, to shrub dominance, to a mixed shrub-tree community (with young trees) before the sequence is reset by a stand-replacing fire. Evidence exists to suggest that this type of dynamic may be naturally characteristic of some sagebrush ecosystems on the Colorado Plateau (for example, Rowlands and Brian, 2001; Harris and others, 2003). Finally, the studies conducted at Mesa Verde NP (Floyd and others, 2004) and on the Uncompahgre
Plateau (Eisenhart, 2004) provide evidence for the third type of system-piñon-juniper forests - which is characterized by infrequent, stand-replacing fires carried by tree canopies.

\section{Insect and Disease Outbreaks}

The roles of insect and disease outbreaks in dryland ecosystems are poorly understood. In montane and boreal forests, insects are recognized as major agents of disturbance (for example, Veblen and others, 1991; Logan and others, 2003). It is believed that the occurrence of insect outbreaks in treedominated ecosystems is linked with climatic conditions that diminish the vigor and insect resistance of host plants and/or affect life cycles and dispersal patterns of insect herbivores (Swetnam and Betancourt, 1998; Logan and others, 2003). In piñon-juniper ecosystems, outbreaks of the bark beetle Ips confusus (piñon ips) can be triggered by drought conditions that weaken host-tree populations (Leatherman and Kondratieff, 2003). Drought and ips beetle outbreaks in combination can act as broad-scale disturbances in these systems, as reflected by the massive mortality that has occurred recently in piñon populations across the southern Colorado Plateau region in response to the early $21^{\text {st }}$ century drought (USDA Forest Service, 2003). As with fire, insect outbreaks thus can interact with climate to generate long-term changes in vegetation structure (Allen and Breshears, 1998). Insect- or pathogen-generated changes in vegetation structure can have multiple ecosystem-level consequences due to vegetation interactions with nutrient cycles, hydrologic processes, and geomorphic processes.

\section{Herbivory and Trampling}

Herbivory and trampling are additional natural disturbances in dryland ecosystems of the region. Potential ecosystem-level effects of herbivory and trampling were discussed above, but actual effects will vary in relation to ecosystem characteristics (for example, climatic conditions, soil properties, and vegetation structure and composition) and disturbance characteristics. Similar to other disturbances such as fire, a key consideration for ecosystem management and monitoring is the regime of herbivory and trampling that is considered natural for particular ecosystems.

Predominant types of herbivores and the spatial patterning, temporal patterning, magnitude, selectivity, and synergistic relationships of herbivory and trampling likely varied among dryland ecosystems prior to European settlement. At the time of contact, large native ungulates such as elk and bison (Bison bison) were uncommon in most dryland ecosystems of the Intermountain West in comparison with the Great Plains region east of the Rocky Mountains (Mack and Thompson, 1982; Grayson, 1994). Probable factors affecting regional-scale variations include landscape characteristics (for example, availability of forage and perennial water, presence and extent of topographic barriers, proximity to other favorable habitats), nonhuman predation, and hunting activities of pre-European human populations (Truett, 1996). Truett (1996) proposed that water scarcity and hunting by pre-European peoples were primary factors explaining low numbers of large 


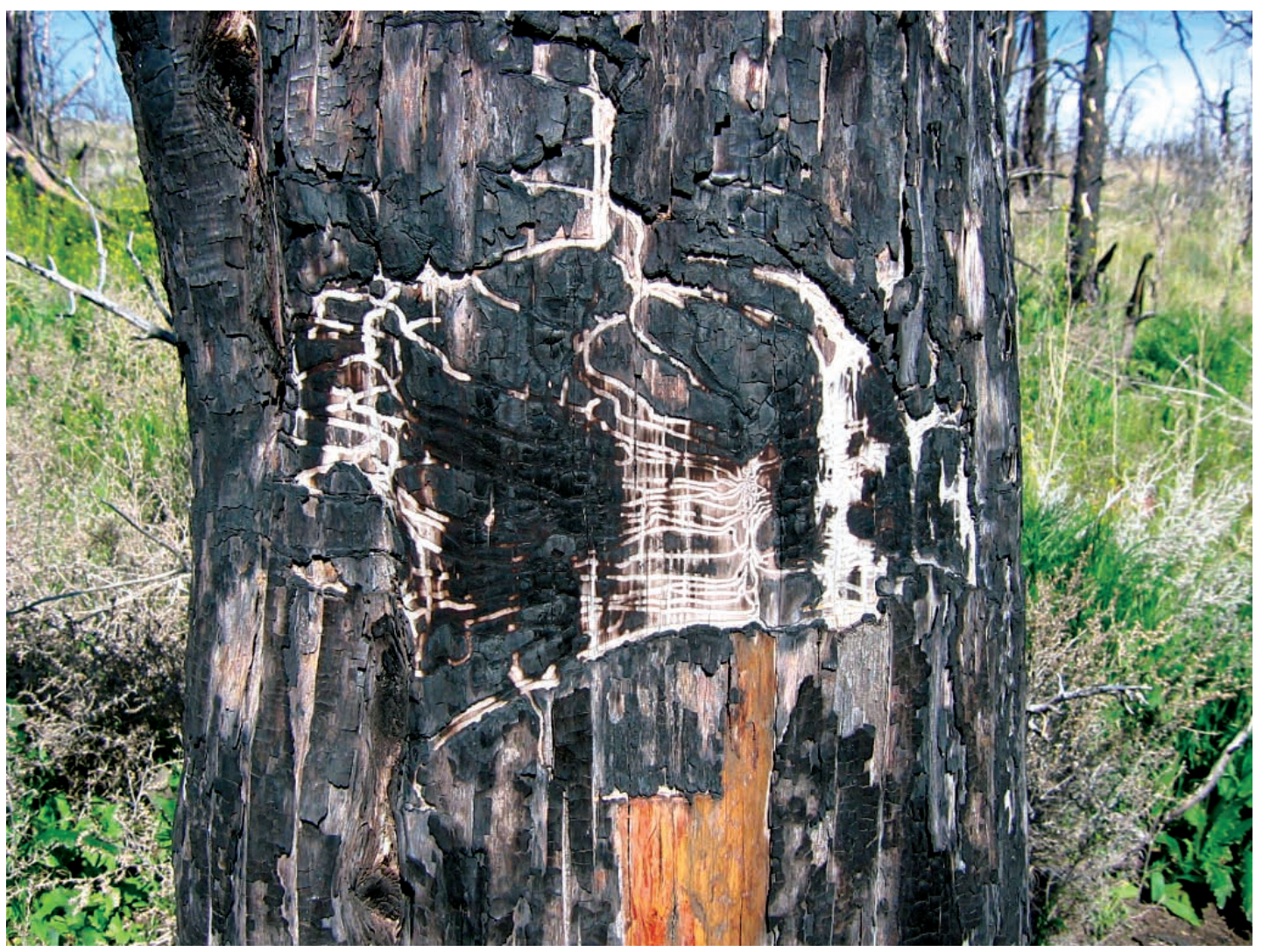

Gallery of a cedar bark beetle (Phoeosinus sp.) on Utah juniper (Juniperus osteosperma) that subsequently was burned in a wildfire, Mesa Verde National Park, Colorado. Photograph by Mark Miller, USGS.

ungulate herbivores encountered by early Europeans throughout much of the American Southwest (see Allen, 1996).

Archaeological findings suggest that small numbers of bison may have been present occasionally in some dryland locations on the Colorado Plateau during late-Holocene times (for example, Mead and others, 1991). But overall, herbivory and trampling by large ungulates probably were relatively minor disturbances in most dryland ecosystems of the region during the period prior to European settlement.

\section{Landscape-Level Relationships}

This report has focused on functional relationships among components of dryland ecosystems, but for purposes of ecosystem management and monitoring it also is important to recognize functional relationships among ecosystems in landscapes (Wiens and others, 2002). A landscape is a spatially structured mosaic of different types of ecosystems interconnected by ecological flows of materials (for example, water, sediments), energy, and organisms. Included in this definition is the notion that some of these flows may represent disturbances or stressors (fig. 8). A landscape perspective is essential for management and monitoring of bounded reserves such as NPS units where ecosystems within parks can be significantly affected by activities occurring well outside park boundaries. Consideration of landscape-level processes also can be important for assessing whether ecological conditions or events in one park location might generate ecological consequences elsewhere within the park (Reiners and Driese, 2001).

Several aspects of landscape structure must be considered when assessing functional relationships among ecosystems in landscapes. These include ecosystem (or patch) type, ecosystem context, ecosystem condition, and ecosystem size (Groves and others, 2002; Wiens and others, 2002). Ecosystem context refers to the spatial configuration and connectivity of ecosystems (fig. 8). Connectivity is the degree to which ecological flows can occur between ecosystems in a landscape. Connectivity depends on spatial configuration, but it also is strongly dependent on the process of interest and the degree of contrast between ecosystems. For example, two adjacent ecosystems may be connected hydrologically due to their location within a particular watershed, but differences in vegetation structure may cause the same two adjacent ecosystems to be disconnected with respect to the movement patterns of particular organisms or the transmission of disturbances such as fire. In this example, the degree of cross-boundary contrast does not affect hydrologic connectivity but it strongly affects boundary permeability to 


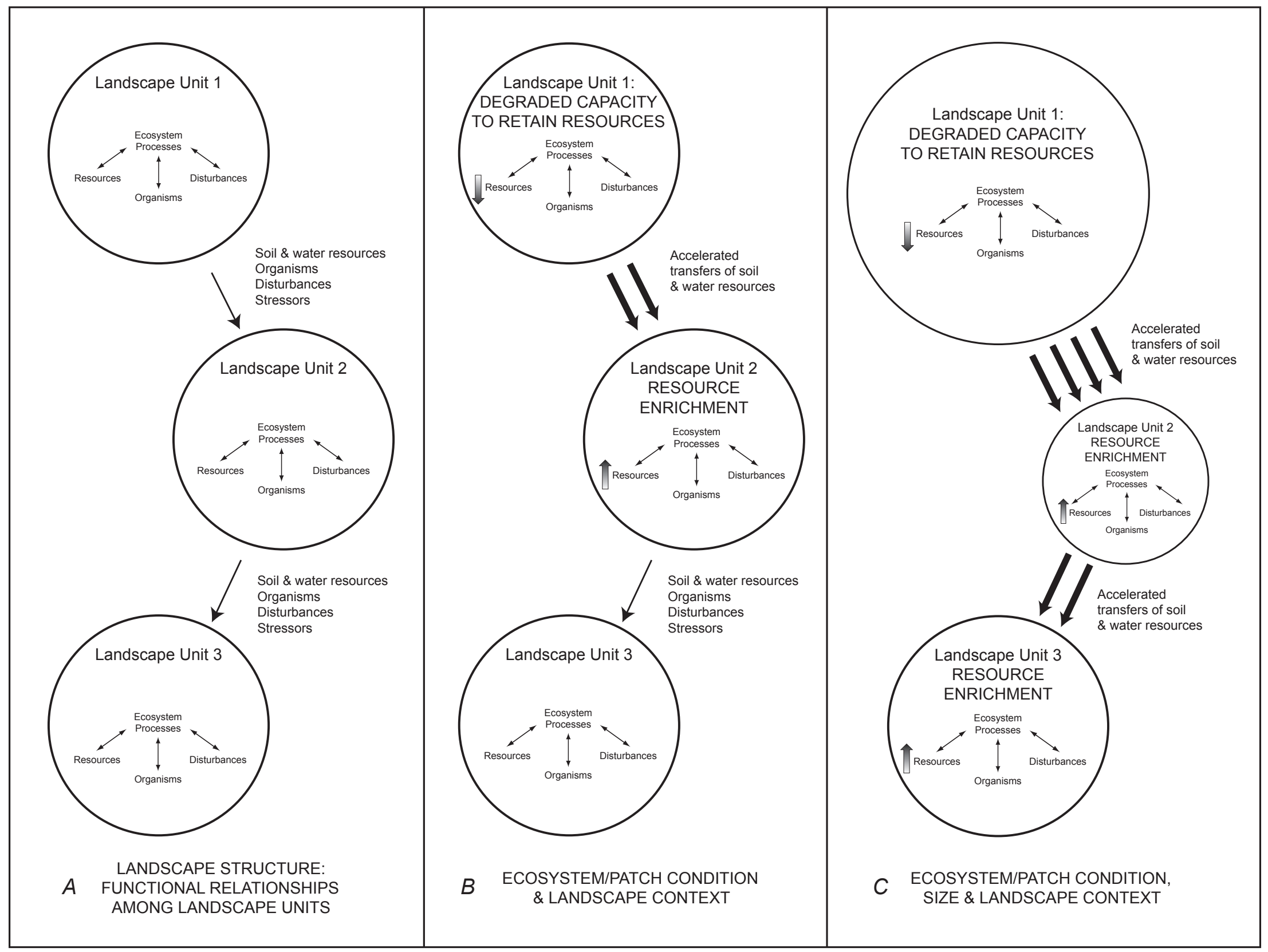

Figure 8. Examples of landscape-level processes and attributes important for ecosystem monitoring. In $A$, landscape units are functionally connected by flows of soil and water resources, organisms, disturbances, and stressors. In $B$, degraded conditions in Unit 1 are shown to cause resource enrichment in Unit 2-illustrating the importance of landscape context. In $C$, degraded conditions in Unit 1 are propagated to Unit 3 due to increased size of Unit 1 and decreased size of Unit 2. 
organisms and disturbance. From an ecosystem perspective, condition refers to the functioning of ecological processes required to sustain ecosystem characteristics including abiotic and biotic structure, productivity, rates of biogeochemical cycling, and natural disturbance regimes. The condition of ecosystems in the landscape can affect among-system flows and the ecological consequences of among-system flows. For example, a diminished capacity for soil and water retention in one ecosystem can result in accelerated resource transfers to connected ecosystems (fig. 8B). Consequences of resource enrichment in the receiving ecosystem are dependent on conditions there. If invasive species are present in the receiving ecosystem, resource enrichment may result in rapid population expansion (Davis and others, 2000; With, 2002). When considered with respect to individual species, ecosystem condition is equivalent to the notion of habitat quality (Wiens and others, 2002).

The meaning of ecosystem size is intuitive, and ecosystem size (or changes in ecosystem size) can affect the type, magnitude, and consequences of among-system flows (fig. $8 C$ ). For ecosystems characterized by large-scale disturbance regimes (for example, extensive fire), it may be necessary to expand the notion of ecosystem size to encompass the amount of area required for the ecosystem to persist under the influence of characteristic large-scale disturbances. This area has been referred to as the minimum dynamic area (Pickett and Thompson, 1978; Peters and others, 1997; Groves and others, 2002).

\section{Predominant Anthropogenic Stressors}

This section briefly describes predominant anthropogenic stressors affecting the structure and functioning of dryland ecosystems in SCPN and NCPN units. Additional information on the significance of these stressors in particular parks can be found in associated NPS reports (Evenden and others, 2002; Thomas and others, 2003; Miller and others, 2003). Details concerning potential ecological effects of these stressors are summarized in tabular format in appendix table $\mathrm{B}$ and in conceptual models presented in the subsequent section of this report.

\section{Visitor Use}

Park use by terrestrial recreationists has been identified as a primary stressor of concern in many NCPN units and, to a lesser degree, in some SCPN units. Most parks experienced rapid growth in the number of annual recreational visits between the mid-1980's and the mid-1990's (Evenden and others, 2002; Thomas and others, 2003). These changes are exemplified by visitation patterns at Canyonlands NP, which averaged 16 percent annual growth in visitation between 1985 and 1995. During the year 2000, Canyonlands received seven times the number of recreational visits that it received in 1980. Zion NP-the most visited park in the NCPN—recorded over two million recreational visits in 2000 , twice the number recorded in 1980. Grand Canyon NP, consistently the mostvisited SCPN park, has recorded over four million visitors every year since 1992 (Thomas and others, 2003). Potential resource impacts associated with terrestrial recreational activities include trampling of soils and vegetation (for example, Cole, 1990), dispersal of invasive exotic species, direct interactions with and disturbances of wildlife, and increased levels of water and air pollutants.

\section{Livestock and Other Large Herbivores}

Livestock use is permitted in parts of one SCPN park (Glen Canyon NRA) and four NCPN parks (Dinosaur NM, Capitol Reef NP, Curecanti NRA, and Black Canyon of the Gunnison NP). Seasonal livestock trailing is permitted in Fossil Butte NM and Bryce Canyon NP, and several other parks repeatedly experience trespass livestock. Most other parks were grazed by domestic livestock at one time, and contemporary soil and vegetation conditions in many parks reflect persistent legacies of past livestock grazing and livestock-management practices (for example, Sydoriak and others, 2000; Neff and others, 2005). Herbivory and trampling by elk (Bandelier NM; Allen, 1996), bison (Capitol Reef NP and Grand Canyon NP), and feral burros (Grand Canyon NP) also occur.

\section{Fire-Regime Alteration}

Ecological legacies of altered fire regimes are significant resource-management issues in many parks (Evenden and others, 2002; Thomas and others, 2003). Altered fire regimes attributable to past livestock grazing (fuel removal) and fire-suppression efforts have caused significant changes in vegetation structure and functioning of associated ecosystem processes. Mediated by changes in vegetation structure, ecosystem-level consequences of altered fire regimes can include diminished hydrologic functioning and increased erosion rates (for example, Wilcox and others, 2003; Davenport and others, 1998; Jacobs and Gatewood, 1999), as well as increased ecosystem susceptibility to drought and other disturbances and/or stressors.

\section{Invasive Exotic Plants}

Invasive exotic plants are recognized as an important component of global environmental change (Vitousek, 1994a; Mooney and Hofgaard, 1999), and they represent a significant resource-management challenge in the Colorado Plateau region. For example, NPS staff have estimated that approximately 24 percent of the total land area of Glen Canyon NRA may be infested with invasive plant species (Thomas and others, 2003). Significant proportions of grasslands found in Canyonlands NP and Arches NP have been converted to dominance by cheatgrass (Bromus tectorum; Evenden and others, 2002), and cheatgrass constitutes approximately 85 percent 
of the dominant understory vegetation at Yucca House NM (Thomas and others, 2003).

Ecological effects of exotic species invasions vary depending on the characteristics of the invader and the invaded ecosystem, but they can include major changes in community composition (Bock and others, 1986), competitive displacement of native species, and alterations of ecosystem-level properties such as disturbance regimes (D'Antonio and Vitousek, 1992; Mack and D'Antonio, 1998) and soil-resource regimes (Vitousek, 1990; Evans and others, 2001). Many invasive plant species also possess physiological traits that will enable them to benefit from aspects of global change such as increased levels of atmospheric $\mathrm{CO}_{2}$ and warmer minimum temperatures during winter (Alward and others, 1999; Dukes and Mooney, 1999; Smith and others, 2000).

\section{Adjacent Land use Activities}

Ecological effects of adjacent land use activities also represent a uniform concern among SCPN and NCPN units (Evenden and others, 2002; Thomas and others, 2003). Particular activities of concern include livestock grazing, forest management, urban/exurban development, and emissions of industrial and agricultural pollutants. Potential resource issues associated with adjacent land use activities include altered habitat structure for wide-ranging wildlife species; increased transfers of soil and water resources; emissions of airborne and waterborne pollutants; introductions of exotic plant and animal species; diminished quality of soundscapes, nightskies, and viewsheds; and water diversion and/or regulation.

\section{Air Pollutants}

Airborne particulates, tropospheric ozone, and nitrogen deposition are concerns at several SCPN and NCPN parks (Evenden and others, 2002; Thomas and others, 2003). Acid deposition may be an issue at Mesa Verde NP (Romme, Oliva, and Floyd, 2003). Nitrogen deposition in particular has potential implications for numerous ecological patterns and processes including ecosystem susceptibility to exotic species invasions (Asner and others, 1997; Galloway and others, 2003; Fenn, Baron, and others, 2003). Although current rates of $\mathrm{N}$ deposition generally are low across most of the western United States, there is very little information available for areas immediately downwind of emissions sources (Fenn, Haeuber, and others, 2003; Fenn, Baron, and others, 2003). Notably, modeling indicates potential "hot spots" of $\mathrm{N}$ deposition in the vicinity of Mesa Verde NP and Zion NP (Fenn, Haeuber, and others, 2003).

\section{Global Atmospheric Changes}

Global atmospheric changes attributable to anthropogenic emissions of $\mathrm{CO}_{2}$ and other greenhouse gases are expected to have significant environmental consequences during this century (Houghton and others, 2001). Increasing levels of

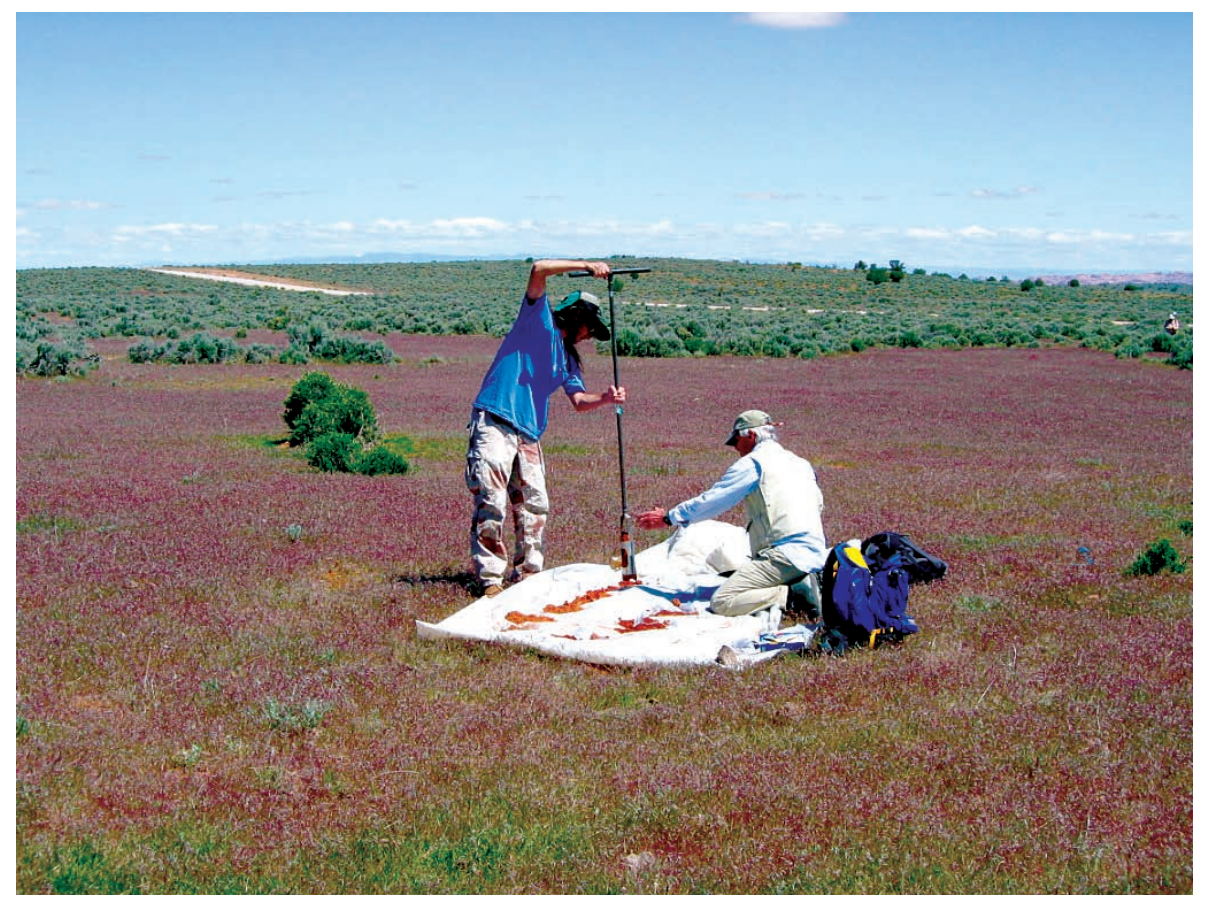

USGS geologists investigating soil properties responsible for spatial patterns of sagebrush (Artemisia tridentata; shrubs in background) and invasive cheatgrass (Bromus tectorum; reddish grass in foreground). San Juan County, Utah. Photograph by Mark Miller, USGS. 


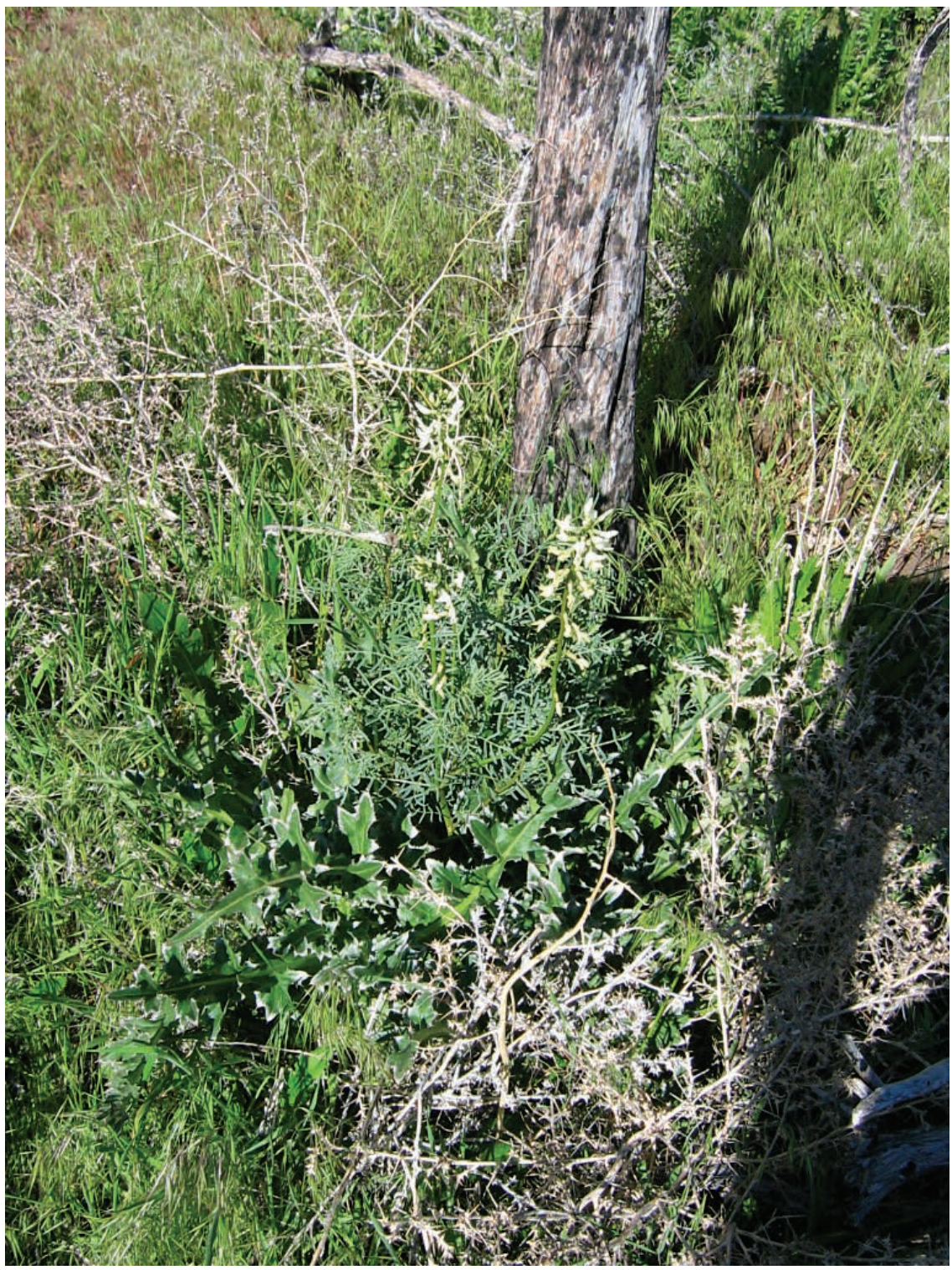

Invasive exotic plants can diminish ecosystem resilience to wildfire even in systems where fire is a natural disturbance process. Wildfire in this piñon-juniper woodland in Mesa Verde National Park led to significant increases in the relative abundance of invasive exotics including cheatgrass (Bromus tectorum) and musk thistle (Carduus nutans). Here these exotics surround Schmoll's milkvetch (Astragalus schmolliae; plant with cream-colored flowers in center of photograph), a rare endemic plant restricted solely to Mesa Verde National Park and the adjacent Ute Mountain Ute Tribal Park. Photograph by Mark Miller, USGS. 


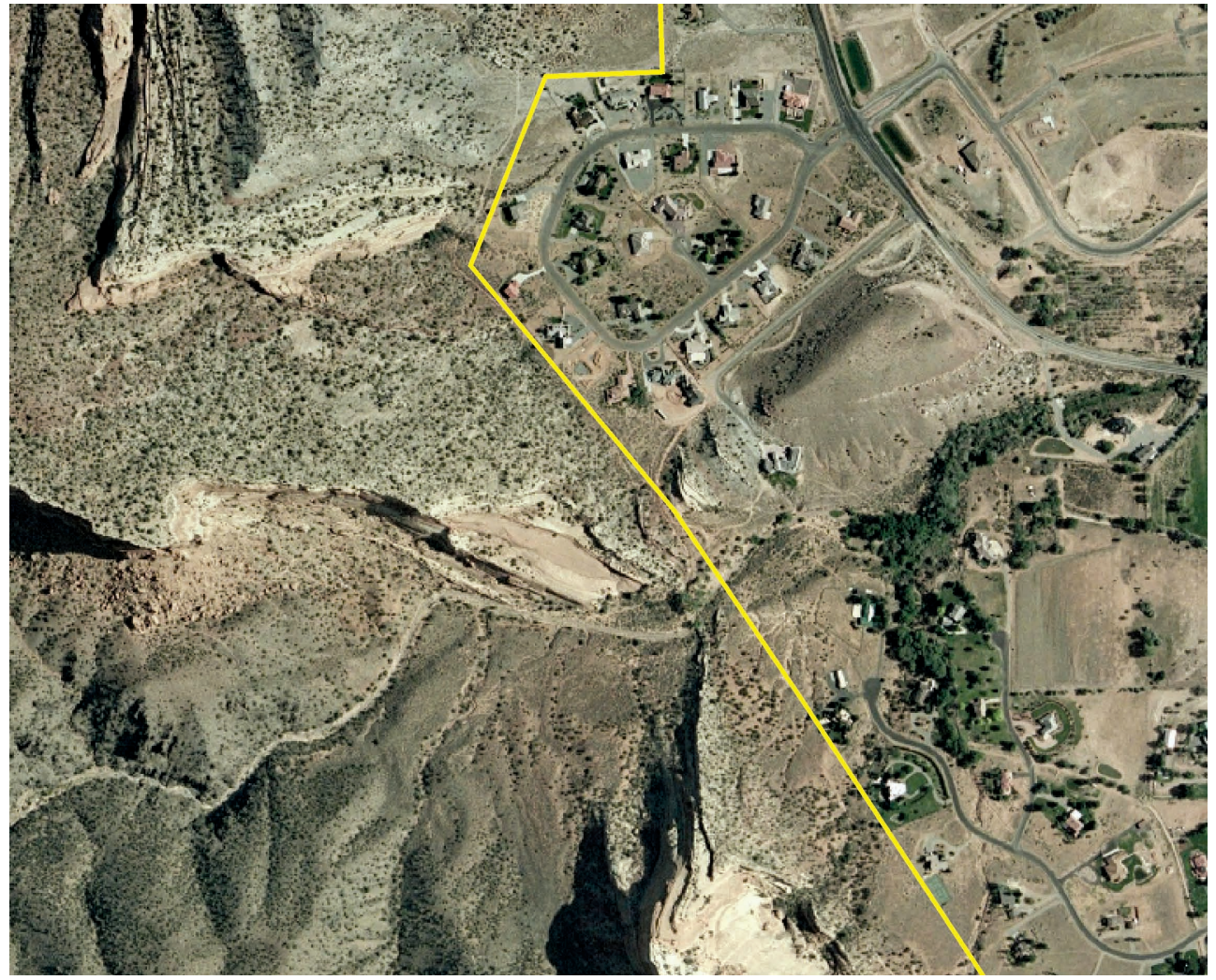

Urban development directly adjacent to the boundary of Colorado National Monument (represented by the heavy yellow line). Width of photograph is 1,400 $\mathrm{m}$ on the ground. Mesa County, Colorado. NPS aerial photograph.

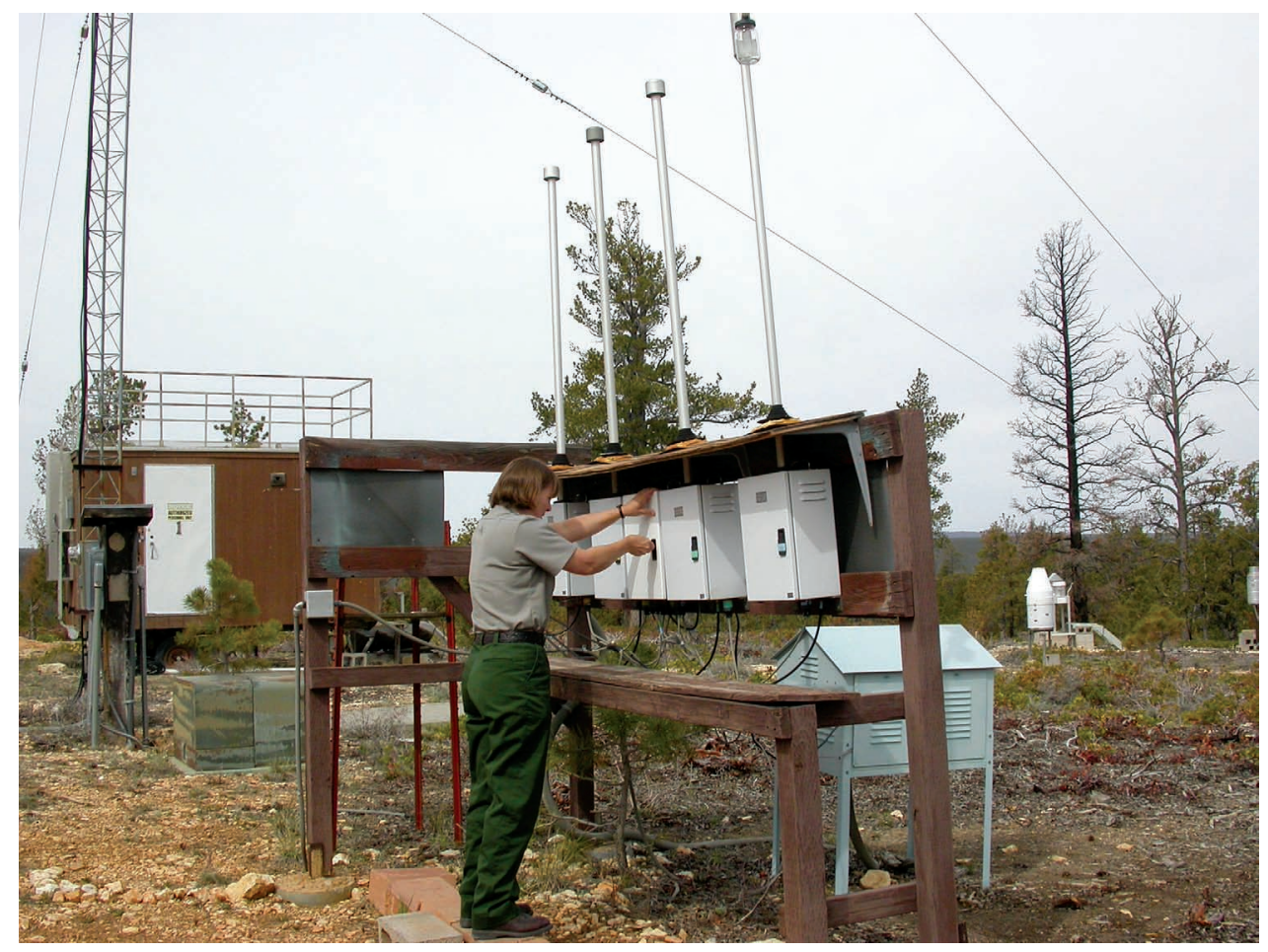

Air-quality monitoring station at Bryce Canyon National Park, Garfield County, Utah. Photograph by Mark Miller, USGS. 
atmospheric $\mathrm{CO}_{2}$, increasing soil and air temperatures, and altered precipitation patterns (including a potential increase in the frequency of extreme events) are likely to affect physiological processes and competitive relationships of vascular plants, nutrient cycles, hydrologic processes, and disturbance regimes - all of which have the potential to greatly alter the structure and functioning of dryland ecosystems (for example, Alward and others, 1999; Ehleringer and others, 1999; Smith and others, 2000; Weltzin and others, 2003) and the sensitivity of these systems to other anthropogenic stressors. Despite modeling efforts, there is great uncertainty about how global atmospheric changes will affect temperature and precipitation patterns in particular regions such as the Colorado Plateau. Uncertainty regarding regional climatic consequences and ecological outcomes of global-change processes greatly compounds the challenges associated with ecosystem management and monitoring.

\section{Ecosystem Dynamics}

In this section, conceptual models are presented to describe hypotheses about how and why dryland ecosystems change through time. These models do not describe characteristic natural dynamics of the many specific dryland ecosystems found in the region (that is, dynamics driven solely by natural disturbances and short-term climatic fluctuations). Instead, they emphasize dynamics associated with a very generalized set of processes and pathways of degradation ${ }^{10}$ that have been described for dryland ecosystems. The intent is that an emphasis on degradational dynamics will best highlight ecosystem attributes that should be monitored for purposes of sustaining ecosystem integrity. The models are intended to depict general ways in which natural drivers (for example, climate and disturbance) interact with stressors and/or management actions to affect the likelihood of these degradational changes. Because of the generalized nature of these models, they will require refinement for site-specific applications. Following the models, this section ends with a brief discussion of factors affecting the susceptibility of dryland ecosystems to change.

\section{Background—Alternative Ecosystem States}

Sustainable ecosystems, as defined by Chapin and others (1996), are persistent. Through the typical pattern of dynamics driven by natural disturbances and climatic fluctuations, such ecosystems maintain their characteristic diversity of major functional groups, productivity, and rates of biogeochemical

\footnotetext{
${ }^{10}$ For purposes of this report, degradation is defined as an anthropogenic reduction in the capacity of a particular ecosystem or ecosystem component to perform desired functions such as the conservation of soil and water resources or the maintenance of native biodiversity. Degradation also can be interpreted as an anthropogenic reduction in the capacity of a system to maintain itself within the natural range of variability or within the range of desired conditions specified by ecosystem managers.
}

cycling (Chapin and others, 1996). Inherent in the notions of ecosystem sustainability and persistence is the hypothesis that ecosystems can be caused to shift from one state to an alternative state. ${ }^{11}$ Though capable of existing on the same site, these alternative ecosystem states are distinguished by relatively large differences in structure and in rates of ecological processes such as erosion, nutrient cycling, and disturbance regime. Such differences in structure and processes typically are matched by great differences in ecosystem dynamics. A transition from one state to an alternative state may occur gradually or relatively rapidly as the result of natural processes (for example, extreme climatic disturbances) or human actions (for example, land use activities). Frequently, human actions and natural processes interact to cause persistent transitions among states (Westoby and others, 1989; Bestelmeyer and others, 2003; Stringham and others, 2003; Bestelmeyer and others, 2004).

Although some transitions may be caused solely by natural processes, of greatest concern from a conservation perspective are anthropogenic transitions which result in degraded ecosystem states. Ecosystems that have been driven across thresholds of degradation generally cannot be restored to previous conditions simply by removing the stressor. Costly, manipulative restoration efforts are typically required (Hobbs and Norton, 1996; Whisenant, 1999; Sydoriak and others, 2000; Suding and others, 2004). The success of such restoration efforts usually is uncertain, and in some cases complete restoration may be impractical due to financial and technical constraints. Dryland ecosystems and aquatic ecosystems are the most frequently cited examples of systems characterized by multiple alternative states (Rapport and Whitford, 1999; Whitford, 2002; Scheffer and Carpenter, 2003).

\section{Common Pathways and Processes of Dryland Degradation}

The conceptual framework of alternative states is a useful one for identifying monitoring needs associated with goals of sustaining the health or integrity of dryland ecosystems. This alternative-state framework is depicted graphically in figure 9. In this framework, the reference state (state $A$, defined on a site-specific basis by climate, soil, and landscape setting) is represented by a dynamic ecosystem in which the characteristic abiotic and biotic components and processes are present and functioning within the natural range of variability, including processes that confer resistance and resilience to

\footnotetext{
${ }^{11}$ As applied here, state is a dynamic concept that (1) encompasses ecological processes such as natural disturbance and nutrient cycling, and (2) recognizes that plant community composition and structure on a particular site can vary spatially and temporally due to disturbance/successional processes and short-term climatic fluctuations. In contrast with these within-state dynamics, between-state dynamics reflect persistent changes in structure and processes that are not easily reversed through typical successional processes. For in-depth discussion of these topics, see Stringham and others (2003); Briske and others (2003); and Bestelmeyer and others (2003, 2004).
} 


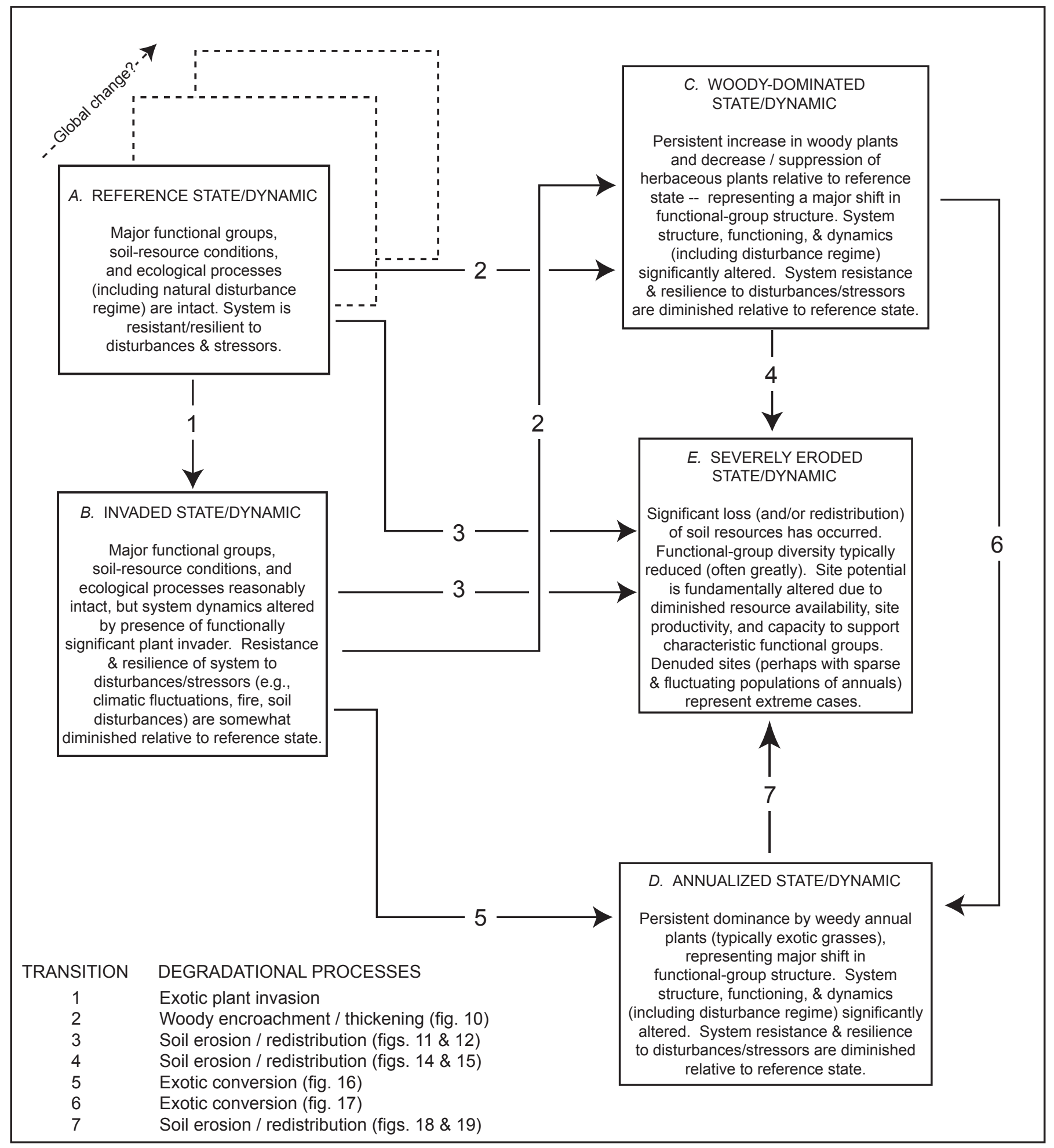

Figure 9. Conceptual model depicting major types of degraded alternative states (boxes $B$ through $E$ ) that characterize dryland ecosystems of the region. Numbered arrows reflect general ecological processes responsible for transitions among states (see accompanying figures for detailed process models). Although not shown here, each state is characterized by a typical pattern of dynamic behavior. For state $A$, that pattern of behavior encompasses the "natural range of variability." Dashed boxes associated with state $A$ reflect the likelihood that global-change processes (for example, altered atmospheric chemistry, temperatures and precipitation) will cause future patterns of variability to drift away from historic patterns. 
natural disturbances and anthropogenic stressors. However, as a consequence of on-going global-change processes (for example, altered atmospheric chemistry, temperatures, and precipitation patterns), managers should recognize that future ecosystem characteristics are likely to drift away from historic patterns of variability even in the absence of local land use effects. Accordingly, the concept of the "reference state" should be sufficiently flexible to account for uncertain trajectories of global atmospheric change (for example, Currie, 2001; Shafer and others, 2001; Hannah and others, 2002; Walther and others, 2002) as well as factors such as altered landscape configurations and the introduction of invasive exotic species to regional and local species pools.

Despite uncertainties associated with future trajectories of change, four commonly observed types of degraded dryland states remain pertinent for purposes of ecosystem management and monitoring (fig. 9, boxes $B$ through $E$ ). These are described here as follows:

- The invaded state (state $B$ ) —characterized by the presence of a functionally significant invasive exotic plant (for example, Bromus tectorum). System structure and functioning are somewhat altered relative to the reference state, but major functional groups and associated ecosystem processes generally remain intact. Presence of the invader may affect ecosystem resistance or resilience to natural disturbances or anthropogenic stressors.

- The woody-dominated state (state $C$ ) — characterized by a persistent increase in the ratio of woody plant biomass to herbaceous plant biomass relative to the reference state. Associated with this major structural change, ecosystem functioning (for example, disturbance regimes, rates of geomorphic and biogeochemical processes) is also significantly altered relative to the reference state.

- The annualized state (state $D$ ) - characterized by persistent ecosystem dominance by weedy annual plants-often including invasive exotics species such as Bromus tectorum. Associated with this major structural change, ecosystem functioning (for example, disturbance regimes, rates of geomorphic and biogeochemical processes) also is significantly altered relative to the reference state.

- The severely eroded state (state $E$ ) — characterized by severe loss or redistribution of soil resources. Site conditions have been fundamentally altered due to diminished (or persistently redistributed) resource availability, site productivity, and site capacity for supporting biotic functional groups characteristic of state $A$.

Depending on site-specific properties of particular ecosystems, there may be numerous expressions and intergradations of these four basic types of degraded states. In addition, there is tremendous variability among particular sites in their susceptibility to various transitions depicted in figure 9 . Transition susceptibility varies as a function of (1) ecosystem exposure to driving processes, and (2) ecosystem resistance and resilience to driving processes. These factors are discussed briefly at the end of this section.

The following are conceptual models describing degradational processes associated with transitions between states depicted in figure 9. As with figure 9, these process-based models are necessarily generalized and will require modification for site-specific applications. The relative significance of processes depicted in the models can be expected to vary widely among sites. The models are intended to assist managers in the consideration of ecosystem attributes to be included in long-term monitoring programs designed to support goals of sustaining the health or integrity of dryland ecosystems. The models are not meant to imply that ecosystem degradation is the certain outcome of particular factors or processes.

\section{Transition 1-Exotic Plant Invasion}

The transition from the desired state to the invaded state is caused by the establishment and spread of a functionally significant plant invader. Propagule dispersal clearly is an important factor in this transition, but resources also must be available if the introduced population is to reach a size sufficient for it to affect ecosystem functioning. Davis and others (2000) recently proposed a simple conceptual model illustrating their hypothesis that an ecosystem becomes more susceptible to invasion when there is an increase in the amount of resources that otherwise limit invasion. According to this model, factors that cause a pulse in resource supply (for example, precipitation events or fire) or a reduction in resource uptake (for example, episodic mortality of community dominants) may enable the rapid population expansion of responsive invaders that previously existed in the ecosystem at low levels. Other workers also have emphasized the importance of temporal and spatial patterns of resource availability as factors affecting ecosystem susceptibility to invasion (Johnstone, 1986; With, 2002). Consistent with the resource-based hypothesis of Davis and others (2000), there is increasing evidence that ecosystems or microsites that are rich in soil resources are particularly susceptible to invasion by exotic species (Stohlgren and others, 1999; Levine and D'Antonio, 1999; BúrquezMontijo and others, 2002).

For example, the pulsed population expansion of Bromus tectorum in a relatively undisturbed grassland in Canyonlands NP was attributed to enhanced soil-moisture conditions resulting from an El Niño episode (Belnap and Phillips, 2001). Subsequent to this population expansion, community dynamics in relation to interannual climatic fluctuations were substantially different than prior to El Niño. In experimental studies, Smith and others (2000) found that the presence of the exotic annual grass red brome (Bromus madritensis ssp. rubens) in an otherwise intact Mojave Desert ecosystem affected ecosystem response to elevated concentrations of atmospheric $\mathrm{CO}_{2}$. Similarly, the presence of invasive exotic plants can significantly degrade the resilience of dryland ecosystems to wildfire (Brooks and others, 2004), thereby increasing the likelihood 
of a subsequent transition to a state dominated by an invader which promotes recurring fire (for example, transition 5 and state $D$ in fig. 9).

\section{Transition 2-Woody Plant Encroachment/Thickening}

A persistent increase in the relative dominance of woody vegetation is perhaps the most widely documented transition in dryland ecosystems around the world (Archer, 1994; Archer and Stokes, 2000; see http://cnrit.tamu.edu/ rlem/faculty/archer/bibliography.html). Factors proposed most commonly as explanatory mechanisms include excessive grazing and associated trampling by domestic livestock, active fire-suppression efforts, and climate (fig. 10). Elevated atmospheric $\mathrm{CO}_{2}$ also has been suggested as a factor (Polley and others, 1996, 1997), although Archer and others (1995) argued that $\mathrm{CO}_{2}$ enrichment is an insufficient explanation for observed patterns of vegetation dynamics. Climate plays an important role due to effects on population dynamics and competitive relations of herbaceous versus woody plants, but persistent overgrazing by domestic livestock generally has been implicated as the most important driver of transitions involving increasing dominance of unpalatable woody plants (Archer and others, 1995; Van Auken, 2000). Selective herbivory can affect the competitive relationships of plants, favoring the establishment and growth of unpalatable plants over those of palatable plants (Briske and Richards, 1994). The reduction of aboveground herbaceous biomass and litter by grazing also can reduce the availability of fine fuels required to support a regime of frequent surface fires.
Where such a fire regime is important for constraining the dominance of fire-intolerant woody vegetation, the removal of fine fuels by grazing may be more important than reduced herbaceous competition or active fire-suppression efforts as a driver of ecosystem change (Archer, 1994; Archer and others, 1995; Van Auken, 2000).

In this region, examples of persistent woody transitions outside the range of natural variability include juniper encroachment in grasslands of northern Arizona (Johnsen, 1962; Jameson, 1962) and thickening of juniper and piñon in grasslands and savannas of north-central New Mexico (for example, Bandelier NM; Allen, 1989). These examples correspond with the piñon-juniper grass savanna ecosystem (sensu Romme, Floyd-Hanna, and Hanna, 2003; table 3), which is characterized by a natural disturbance regime of frequent, low-severity surface fires. This model also may apply to former sagebrush steppe ecosystems and piñon-juniper shrub woodlands (Romme, Floyd-Hanna, and Hanna, 2003; table 3) where land use activities have altered ecosystem structure, lengthened fire-return intervals, and increased the range-wide proportion of systems that are shrub- or tree-dominated (Connelly and others, 2004). In some circumstances, transition to this woody-dominated state may increase the likelihood of subsequent transitions to eroded or annualized states (that is, transitions 4 and 6 to states $E$ and $D$ in fig. 9). It is important to recognize that this model does not apply to piñon-juniper forest ecosystems found at Mesa Verde NP (Romme, FloydHanna, and Hannah, 2003) and possibly elsewhere. Nor does it apply to sparse desert shrublands or semidesert grasslands referred to as galleta-three-awn shrub steppe.

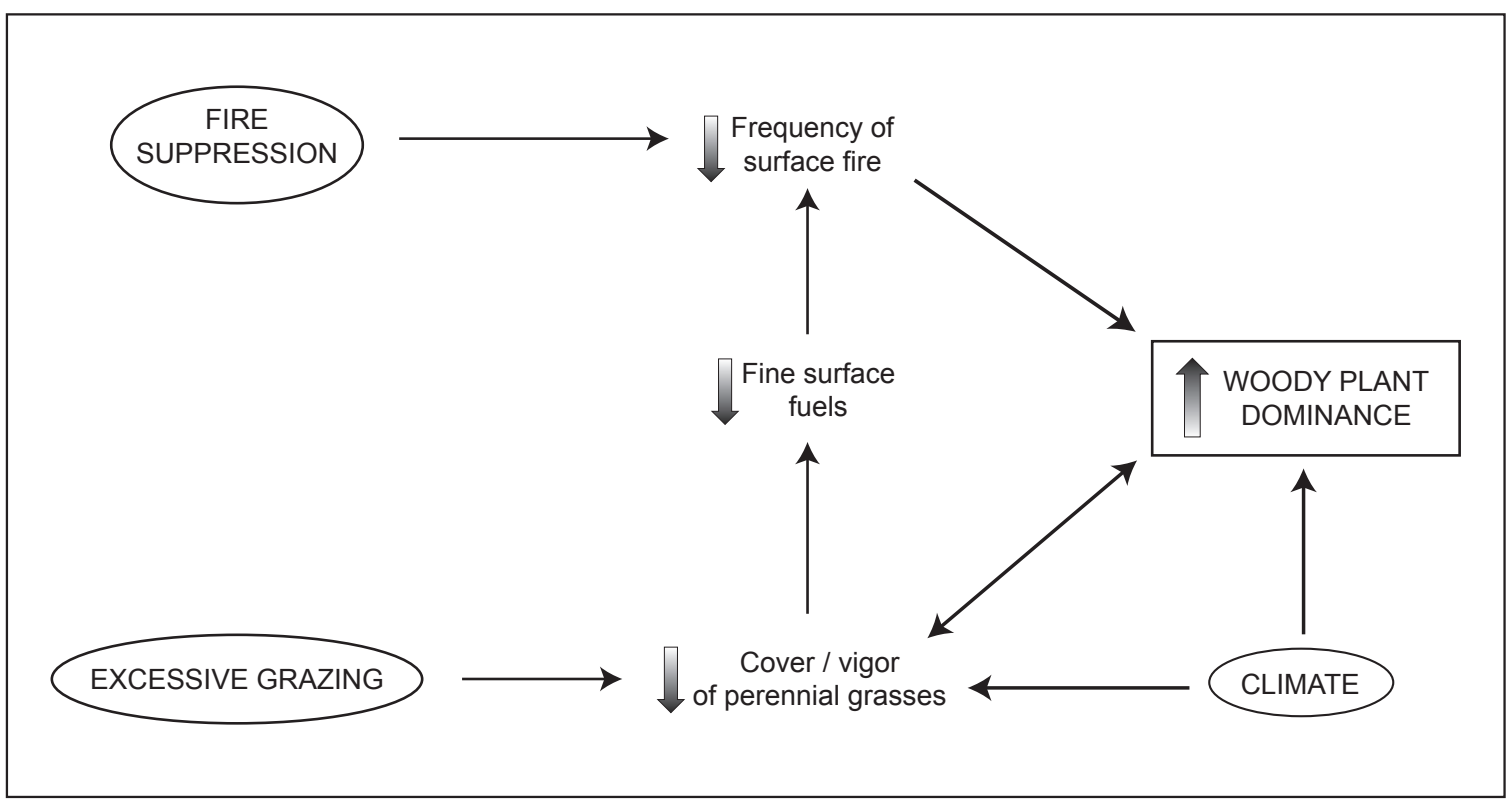

Figure 10. Conceptual model illustrating the processes by which excessive grazing, fire suppression, and climate interactively can lead to increasing dominance by woody plants. 
Table 3. Structure, disturbance dynamics, distribution patterns, current status, and restoration needs of three contrasting types of piñon-juniper ecosystems in western North America: A synthesis and set of hypotheses for further research. HRV = historic range of variability (from Romme, Floyd-Hanna, and Hanna, 2003, p. 346).

\begin{tabular}{|c|c|c|c|}
\hline & Piñon-Juniper Grass Savanna & Piñon-Juniper Shrub Woodland & Piñon-Juniper Forest \\
\hline $\begin{array}{l}\text { Pre-1900 fire } \\
\text { regime }\end{array}$ & $\begin{array}{l}\text { Frequent, low-severity, surface fires car- } \\
\text { ried by grasses }\end{array}$ & $\begin{array}{l}\text { Moderately frequent, high-severity, } \\
\text { crown fires carried by shrubs \& trees }\end{array}$ & $\begin{array}{l}\text { Very infrequent, very high-severity, } \\
\text { crown fires carried by tree crowns }\end{array}$ \\
\hline $\begin{array}{l}\text { Pre-1900 stand } \\
\text { structure }\end{array}$ & $\begin{array}{l}\text { Sparse trees, few shrubs, dense grass, } \\
\text { and other herbs }\end{array}$ & $\begin{array}{l}\text { Sparse to moderately dense trees, sparse } \\
\text { to very dense shrubs, moderately dense } \\
\text { to sparse herbs, all depending on time } \\
\text { since last fire }\end{array}$ & $\begin{array}{l}\text { Dense trees, sparse to moderately dense } \\
\text { shrubs, sparse herbs }\end{array}$ \\
\hline $\begin{array}{l}\text { Pre-1900 stand } \\
\text { dynamics }\end{array}$ & $\begin{array}{l}\text { Low tree density and high herbaceous } \\
\text { biomass maintained in part by recurrent } \\
\text { fire }\end{array}$ & $\begin{array}{l}\text { Seral trend from herb to shrub to tree } \\
\text { dominance, interrupted periodically by } \\
\text { fire which returns a stand to early seral } \\
\text { herb dominance }\end{array}$ & $\begin{array}{l}\text { Stable/stationary tree age structure and } \\
\text { little change in shrub or herbaceous lay- } \\
\text { ers during the long intervals without fire; } \\
\text { very slow recovery after fire }\end{array}$ \\
\hline $\begin{array}{l}\text { Post- } 1900 \text { changes } \\
\text { in disturbance } \\
\text { regime }\end{array}$ & $\begin{array}{l}\text { Reduced fire frequency, great increase in } \\
\text { fire severity }\end{array}$ & $\begin{array}{l}\text { Reduced fire frequency, small increase in } \\
\text { fire severity }\end{array}$ & $\begin{array}{l}\text { Little change in fire frequency or fire } \\
\text { severity }\end{array}$ \\
\hline $\begin{array}{l}\text { Post- } 1900 \text { changes } \\
\text { in structure }\end{array}$ & $\begin{array}{l}\text { Increasing tree density, decreasing her- } \\
\text { baceous biomass }\end{array}$ & $\begin{array}{l}\text { Increasing tree density, decreasing } \\
\text { shrubs and herbs }\end{array}$ & $\begin{array}{l}\text { Little change in tree density or in shrubs } \\
\text { or herbs }\end{array}$ \\
\hline $\begin{array}{l}\text { Overall current } \\
\text { status }\end{array}$ & $\begin{array}{l}\text { Outside HRV for disturbance regime, } \\
\text { structure, \& composition }\end{array}$ & $\begin{array}{l}\text { Outside HRV for disturbance regime, } \\
\text { structure, \& composition }\end{array}$ & $\begin{array}{l}\text { Still within HRV for disturbance regime, } \\
\text { structure, \& composition }\end{array}$ \\
\hline $\begin{array}{l}\text { Implications for } \\
\text { restoration }\end{array}$ & Urgent need for active restoration & Urgent need for active restoration & No need for restoration, protect instead \\
\hline $\begin{array}{l}\text { Current stand age } \\
\text { structure }\end{array}$ & $\begin{array}{l}\text { Very old trees ( }>300 \text { years) present, but } \\
\text { not numerous; young trees }(<150 \text { years }) \\
\text { dominate stands }\end{array}$ & $\begin{array}{l}\text { Very old trees }(>300 \text { years) absent or } \\
\text { rare; young trees }(<150 \text { years }) \text { dominate } \\
\text { stands }\end{array}$ & $\begin{array}{l}\text { Very old trees ( }>300 \text { years) numerous; } \\
\text { stands with all-aged structure, including } \\
\text { old \& young trees }\end{array}$ \\
\hline $\begin{array}{l}\text { Distribution: soil } \\
\text { characteristics }\end{array}$ & Deep, fine-textured soils & Deep, fine-textured soils & Shallow, rocky, or coarse-textured soils \\
\hline $\begin{array}{l}\text { Distribution: pre- } \\
\text { cipitation regime }\end{array}$ & Summer peak in precipitation & Winter peak in precipitation & Variable \\
\hline $\begin{array}{l}\text { Distribution: topo- } \\
\text { graphic character- } \\
\text { istics }\end{array}$ & $\begin{array}{l}\text { Gentle plains and broad valley bottoms, } \\
\text { with few barriers to fire spread }\end{array}$ & $\begin{array}{l}\text { Gentle plains and broad valley bottoms, } \\
\text { with few barriers to fire spread }\end{array}$ & $\begin{array}{l}\text { Rugged slopes, canyons, and mesa tops, } \\
\text { with many barriers to fire spread }\end{array}$ \\
\hline $\begin{array}{l}\text { Distribution: } \\
\text { adjacent vegetation } \\
\text { types }\end{array}$ & $\begin{array}{l}\text { Grasslands, ponderosa pine, or other } \\
\text { types that burn frequently }\end{array}$ & $\begin{array}{l}\text { Grasslands, big sagebrush, or other types } \\
\text { that burn frequently }\end{array}$ & $\begin{array}{l}\text { Desert scrub, "slickrock," or other types } \\
\text { with sparse herbaceous vegetation that } \\
\text { rarely burn }\end{array}$ \\
\hline $\begin{array}{l}\text { Geographic distri- } \\
\text { bution }\end{array}$ & $\begin{array}{l}\text { Most common in northern Mexico, } \\
\text { southern New Mexico \& Arizona, } \\
\text { northern New Mexico, and possibly } \\
\text { southeastern Colorado }\end{array}$ & $\begin{array}{l}\text { Most common in the northern and } \\
\text { central Great Basin and the Colorado } \\
\text { Plateau }\end{array}$ & $\begin{array}{l}\text { Scattered throughout the Colorado } \\
\text { Plateau, Great Basin, central Oregon, } \\
\text { southern Rocky Mountains, and southern } \\
\text { California mountains }\end{array}$ \\
\hline Examples & $\begin{array}{l}\text { Jameson, 1962; Dwyer and Pieper, 1967; } \\
\text { Allen, 1989; Segura and Snook, 1992; } \\
\text { Dick-Peddie, 1993; Miller, } 1999\end{array}$ & $\begin{array}{l}\text { Tausch and others, 1981; Koniak, 1985; } \\
\text { Tausch and West, 1988; Miller and oth- } \\
\text { ers, 1995; Miller and Tausch, } 2001\end{array}$ & $\begin{array}{l}\text { Tausch and others, 1981; Tress and } \\
\text { Klopatek, 1987; Kruse and Perry, 1995; } \\
\text { Wangler and Minnich, 1996; Miller and } \\
\text { others, 1999; Tausch and Nowak, 1999; } \\
\text { Floyd and others, 2000; Waichler and } \\
\text { others, 2001; Floyd and others, } 2004\end{array}$ \\
\hline
\end{tabular}


Although human land use activities frequently are implicated as primary drivers of woody transitions, it is important to recognize that increases in the relative dominance of woody vegetation also can occur in the absence of such activities. Between 1958 and 1996, juniper and piñon increased in sagebrush shrublands on a remote mesa in Grand Canyon NP that was unimpacted by human land use activities (Rowlands and Brian, 2001). Similarly, Harris and others (2003) found a significant increase in the dominance of woody vegetation on an ungrazed mesa in southern Utah between 1948 and 1993. In both cases, increases in the dominance of woody vegetation appear to be driven by natural successional processes. As indicated previously, area-specific research is necessary to evaluate natural disturbance regimes and processes responsible for observed dynamics.

\section{Transition 3-Soil Erosion/Redistribution}

Transition 3 (fig. 9) is associated with accelerated erosional processes that result in a significant and persistent decline in soil-resource availability, site productivity, and site capacity for supporting biotic functional groups characteristic of the reference state. Soil resources can be eroded and redistributed by aeolian processes (fig. 11), fluvial processes (fig. 12), or both. Whether wind or water is the driving force, factors leading to accelerated rates of soil erosion and redistribution are similar. Trampling and other soil-surface disturbances can diminish soil stability by damaging biological soil crusts that protect and retain soils against erosive forces of wind, rain, and runoff (Williams, 1995b; Belnap and Gillette, 1998; Okin and others, 2001). Soil-surface disturbances also can disrupt stable soil aggregates that enhance soil stability and soil infiltration capacity (Thurow, 1991). By reducing herbaceous cover and organic-matter inputs from litter and roots, excessive grazing can diminish soil protection and soil aggregate stability (Thurow, 1991). Reductions in ground cover can result in accelerated erosion due to diminished capacity to obstruct wind and overland flow of water (Davenport and others, 1998; Reid and others, 1999; Ludwig and Tongway, 2000). Depending on site characteristics, such as soil texture, soil structure, and the vertical and horizontal structure of vegetation, reductions in ground cover may result in threshold-like increases in runoff and erosion (Davenport and others, 1998). Because of the complex and poorly understood effects of biological soil crusts on hydrologic processes, in figure 12 some uncertainty is indicated regarding effects of biological soil crusts on water and sediment capture and retention. Off-site conditions (that is, the functional status of adjacent landscape units; fig. 8) can contribute to accelerated rates of erosion. Examples are saltating soil particles that produce aeolian soil

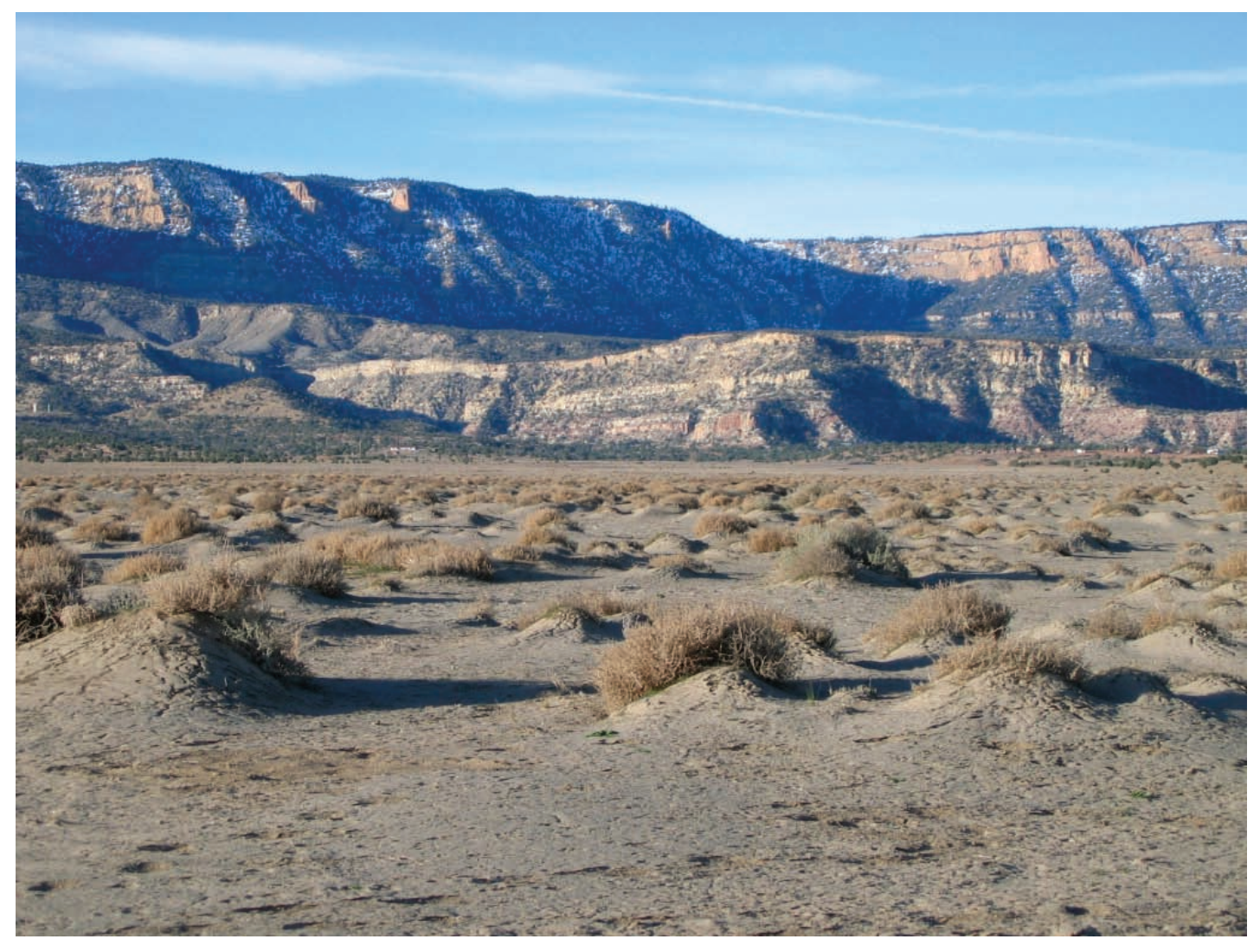

Coppice dunes formed by wind-driven movement of unstable soil where most perennial grasses and shrubs have been removed. Dunes formed where persistent shrubs and exotic annual plants such as tumbleweed (Salsola sp.) captured sediment. Navajo County, Arizona. Photograph by Mark Miller, USGS. 


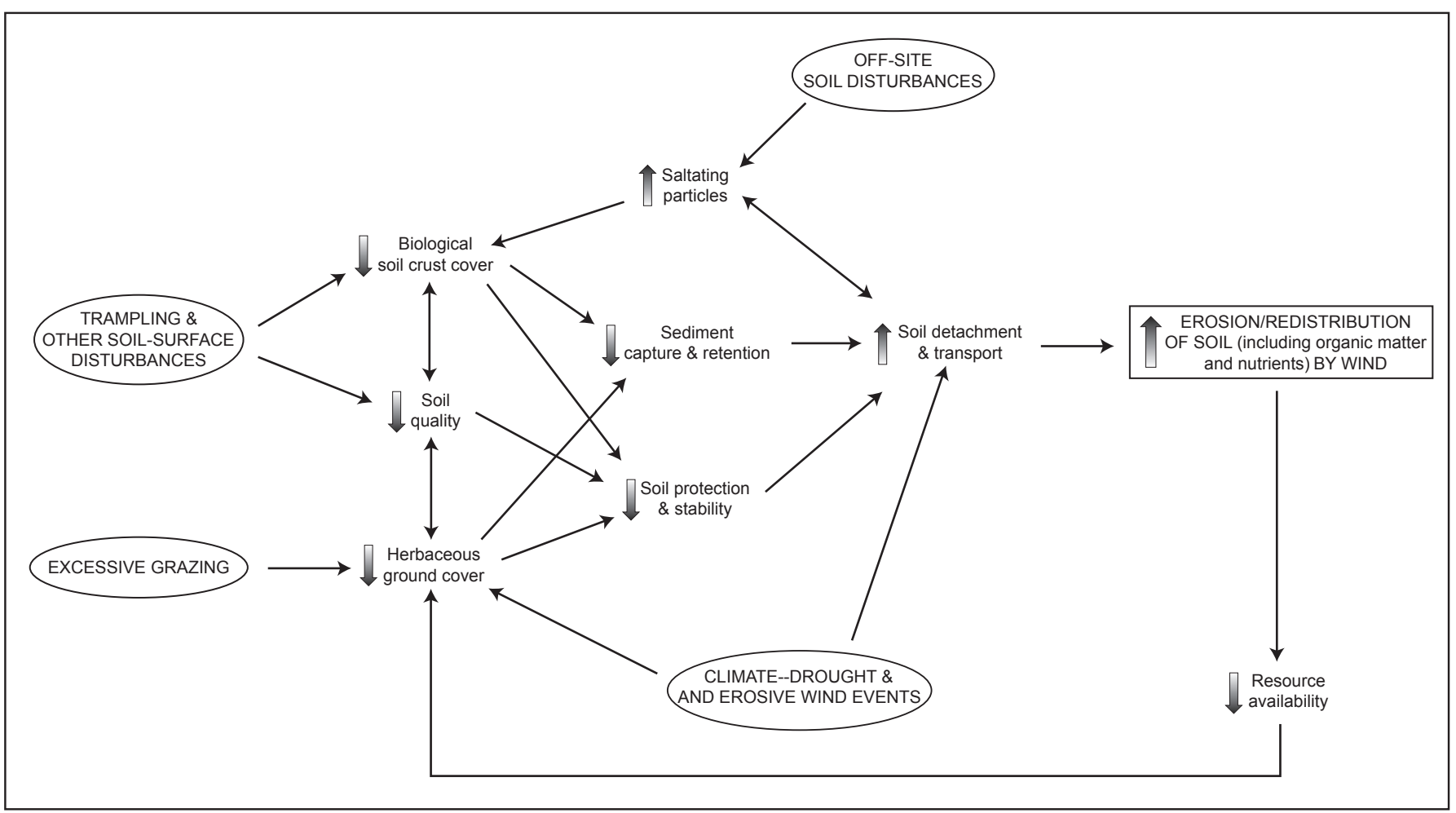

Figure 11. Conceptual model illustrating the processes by which excessive grazing, soil-surface disturbances, off-site soil-surface disturbances, and climate interactively can lead to accelerated erosion/redistribution of soil resources by wind.

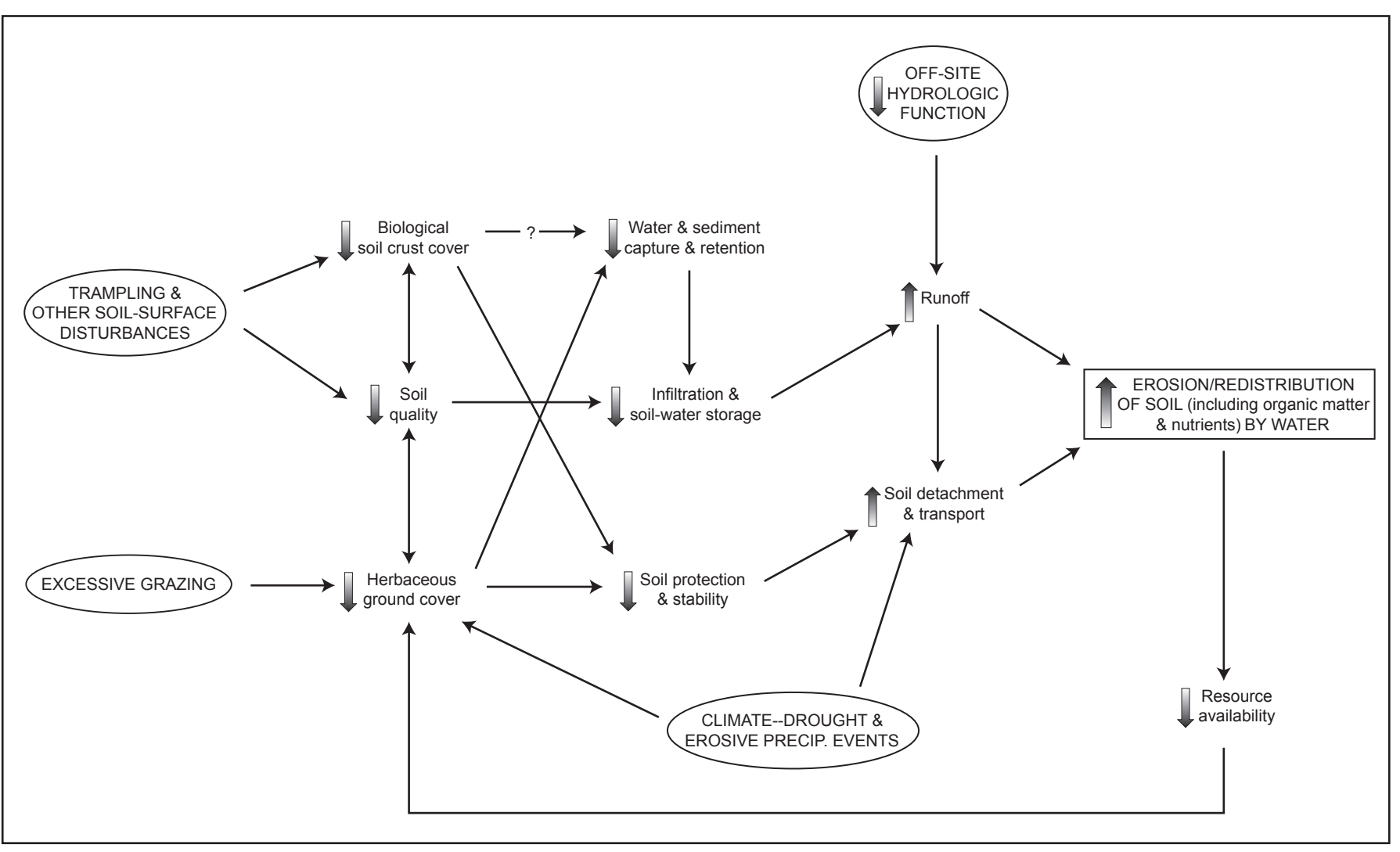

Figure 12. Conceptual model illustrating the processes by which excessive grazing, soil-surface disturbances, off-site hydrologic function, and climate interactively can lead to accelerated erosion/redistribution of soil resources by water. 

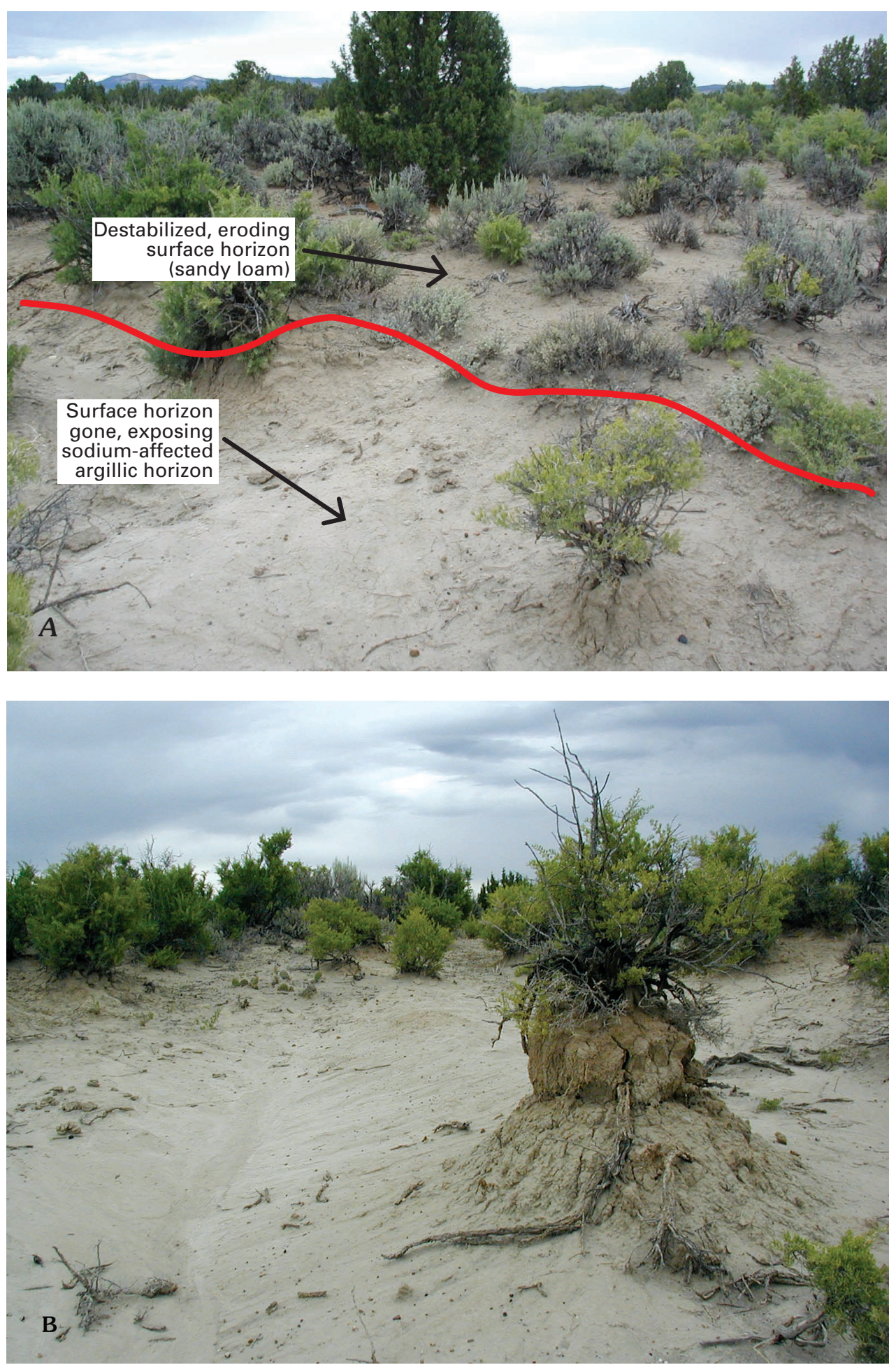

Figure 13. Example of site where accelerated erosion has led to the significant loss of soil resources and persistent alteration of ecosystem structure and functioning (BLM photos). In $A$, the area above the red line retains a sandy-loam surface horizon that, though unstable and eroding, facilitates water infiltration and provides conditions suitable for vascular-plant establishment. Where this thin surface horizon has been lost below the red line, soil physical and chemical properties inhibit plant establishment and facilitate water-driven erosion. Panel $B$ illustrates extreme results of erosion at this site. Photographs are of a site in Headquarters Valley, Grand Staircase-Escalante National Monument, Utah. Soil is transitional between an Elias series (Natriargid) and a Barx series (Calciargid) (Kent Sutcliffe, pers. commun., 2004). 
detachment (fig. 11; Toy and others, 2002) and runoff that causes fluvial soil detachment and transport (fig. 12; Thurow, 1991). Climate plays a role in this transition due to its effects on vegetative ground cover and the frequency of erosive wind and precipitation events (for example, fig. 5). As soil resources are lost due to erosional processes, declining resource availability generates a positive feedback facilitating further declines in vegetative ground cover and further increases in erosion (figs. 11 and 12; for example, Tongway and others, 2003; Friedel and others, 2003; Sparrow and others, 2003).

In the Colorado Plateau region, good examples of this transition can be found on stream-terrace soils that have been impacted by soil-surface disturbances (fig. 13). In this landscape setting, a typical intact soil profile consists of a thin $(0-5$ $\mathrm{cm})$ surface horizon of fine sandy-loam texture that overlies a thick subsurface argillic (clay-rich) horizon with high sodium content caused by capillary rise of alluvial groundwater (for example, the Elias series-for the official series description see http://ortho.ftw.nrcs.usda.gov/cgi-bin/osd/osdname. cgi). Where unimpacted by land use activities, such sites are generally characterized by well-developed biological soil crust communities, productive stands of the $\mathrm{C}_{4}$ bunchgrass Sporobolus airoides (alkali sacaton), and the shrub Sarcobatus vermiculatus (greasewood). Destabilization and loss of the surface horizon expose a horizon with physical and chemical properties that tend to inhibit establishment of vascular plants and biological soil crusts, as well as enhance runoff and waterdriven erosional processes. In all cases where this occurs, ecosystem structure and functioning are persistently altered; in extreme cases, erosion leads to the development of badland topography. Examples similar to those depicted in figure 13 can be found in Capitol Reef NP.

\section{Transition 4-Soil Erosion/Redistribution}

Erosional processes associated with transition 4 (figs. 14 and 15) are similar to those associated with transition 3 (figs. 11 and 12), but in the former, processes are modified due to an increase in the dominance of woody vegetation compared with the reference state. Relative to transition 3, within-site soil redistribution is more important in Transition 4 (figs. 14 and 15). Soil resources transported from interspaces may be captured and retained within the subcanopy environments of woody plants because of interactions of shrubs and trees with wind- and water-driven geomorphic processes. The redistribution of soil resources from intercanopy spaces to subcanopy environments contributes to a positive feedback favoring continued increases in the ratio of woody to herbaceous biomass. Regional examples of the positive-feedback linkage

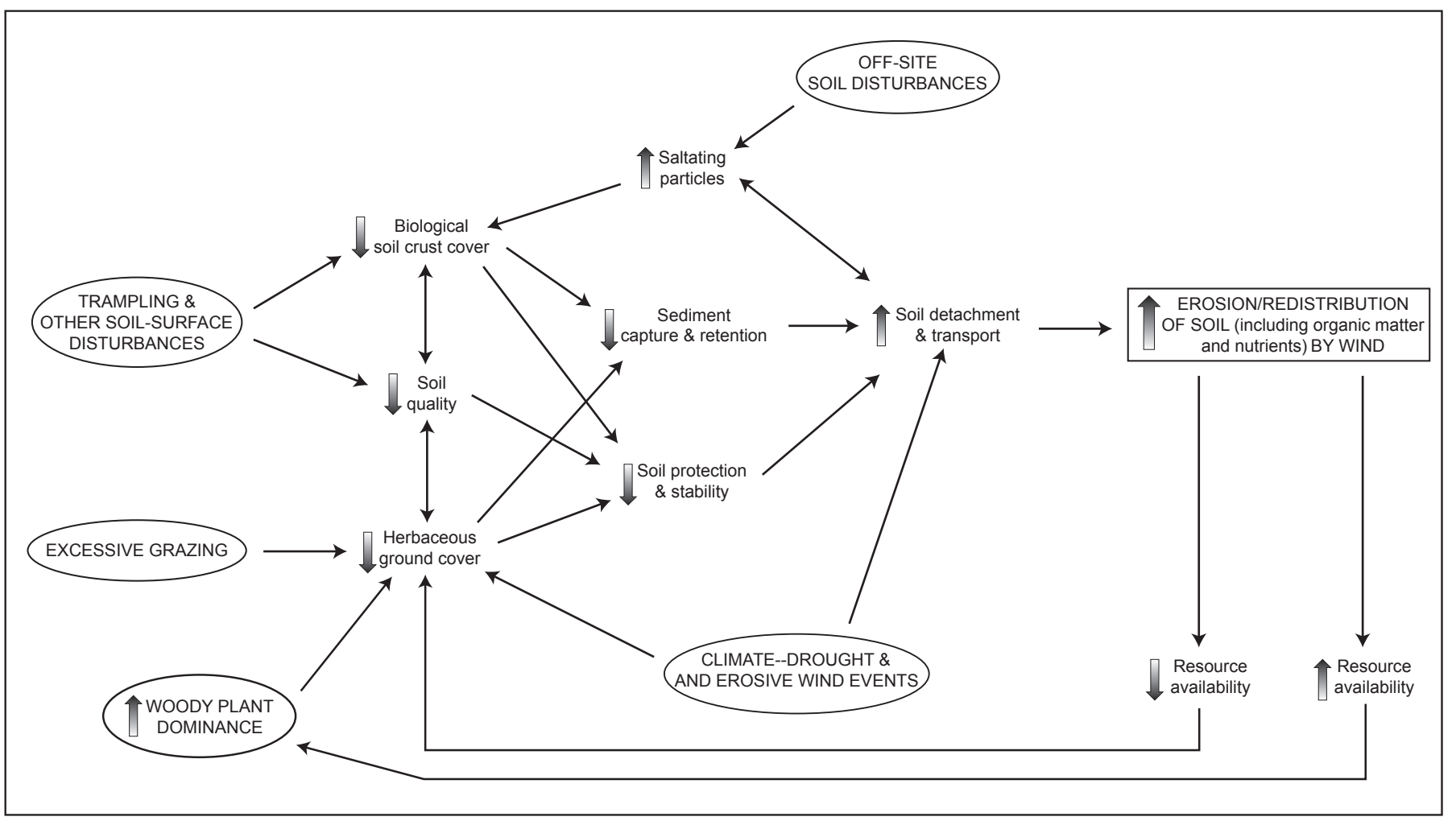

Figure 14. Conceptual model illustrating the processes by which increasing woody-plant dominance, excessive grazing, soil-surface disturbances, off-site soil disturbances, and climate interactively can lead to accelerated erosion/redistribution of soil resources by wind. 


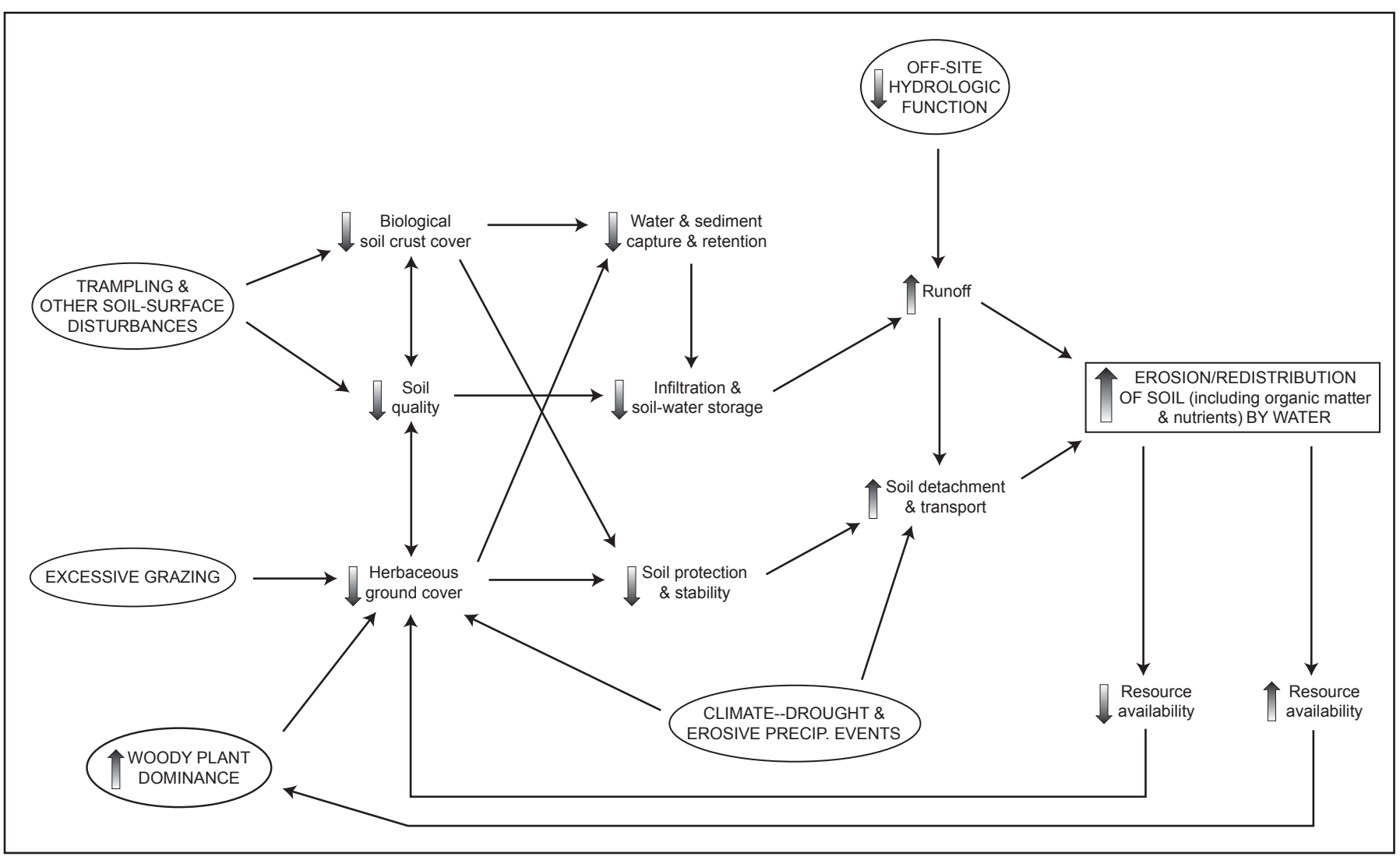

Figure 15. Conceptual model illustrating the processes by which increasing woody-plant dominance, excessive grazing, soil-surface disturbances, off-site hydrologic function, and climate interactively can lead to accelerated erosion/redistribution of soil resources by water.

between soil redistribution and increasing dominance of woody vegetation include coppiced shrublands of Monument Valley (pers. obs.) and piñon-juniper rocklands of Bandelier NM where severe erosion has been facilitated by past grazing and fire-regime alterations that led to increased tree cover and diminished herbaceous cover (Allen, 1989; Wilcox and others, 2003; Davenport and others, 1998; Jacobs and Gatewood, 1999). This positive-feedback model has been proposed as a common pathway of dryland degradation or "desertification" (Schlesinger and others, 1990; Havstad and others, 2000).

\section{Transition 5-Exotic Conversion}

The persistent conversion of dryland ecosystems to dominance by exotic annuals is a widespread pathway of degradation (for example, Billings, 1990; Connelly and others, 2004). Many weedy annuals may be involved, but exotic annual grasses are the most common dominants. Several factors may contribute to processes associated with this transition to an "annualized" state (fig. 16), but all of them invariably affect the availability of resources that otherwise limit population growth in the exotic species (Davis and others, 2000). In this context, resources may include safe sites for germination and establishment (Harper, 1977; Grubb, 1977), as well as water, mineral nutrients, and light. Soil-surface disturbances may facilitate establishment of ruderal exotic species if availability of safe-site opportunities is a limiting factor (Crawley, 1987).

However, if soil-surface disturbances do not ameliorate resource limitations, then soil-surface disturbance alone will not facilitate a transition to exotic dominance (Hobbs, 1991). Excessive grazing can reduce the competitive abilities of native perennial grasses relative to exotic annuals if the former are preferentially grazed, thereby favoring population expansion of lesser grazed exotic annuals. Resource enrichment associated with climatic episodes, fire, resource transfers from adjacent sites, excreta from localized livestock concentrations, or atmospheric $\mathrm{N}$ deposition may facilitate population expansion and persistent conversion to dominance by exotic annuals-particularly if associated factors (for example, selective herbivory by livestock) simultaneously have an adverse effect on native competitors. Increasing dominance by exotic annuals can lead to a dramatic shift in fire regime where annuals drive increases in the abundance and continuity of fine fuels and in the frequency of surface fires (Brooks and others, 


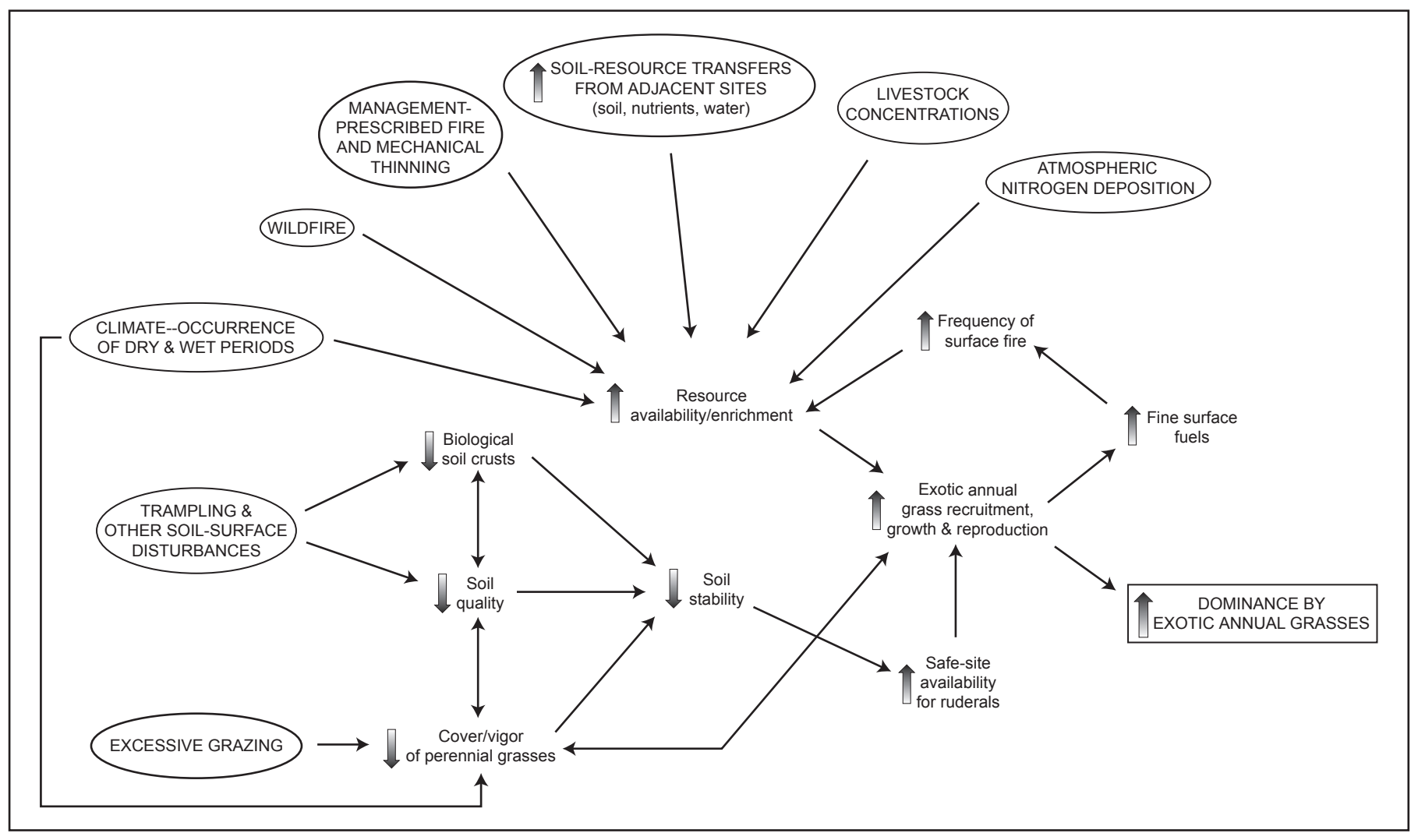

Figure 16. Conceptual model illustrating the processes by which excessive grazing, soil-surface disturbances, managementprescribed fire and mechanical thinning, wildfire, atmospheric nitrogen deposition, concentrated livestock activites, landscape-level soil-resource transfers, and climate interactively can lead to increasing dominance (and site conversion) by exotic annual grasses.

2004). Although a shift in fire regime does not always accompany ecosystem annualization, the positive-feedback linkage between exotic grasses and wildfire is sufficiently widespread to have been proposed as an important element of global change (D'Antonio and Vitousek, 1992). Fenn, Baron, and others (2003) suggested that, in some locations, atmospheric N deposition could trigger fire/exotic grass cycles by increasing resource availability for exotics. Experimental results from the Mojave Desert suggest that increasing levels of atmospheric $\mathrm{CO}_{2}$ may have a similar triggering effect (Smith and others, 2000). Romme, Oliva, and Floyd (2003) expressed concern that invasive exotic species could respond to natural fires in piñon-juniper ecosystems of Mesa Verde NP and subsequently initiate a fire/exotic species cycle. Examples of annualized ecosystems are in several NPS units in the Colorado Plateau region, including Canyonlands NP, Arches NP, Golden Spike NHS, Zion NP, and Capitol Reef NP. In some circumstances, conversion to annuals may accelerate erosional processes that lead to further site degradation (for example, transition 7 to state $E$ in fig. 9).

\section{Transition 6-Exotic Conversion}

Similar to the concerns of Romme, Oliva, and Floyd (2003) regarding the potential for exotic conversion following wildfire in Mesa Verde NP ecosystems, West (1999) suggested that persistent increases in the dominance of woody vegetation could facilitate exotic conversion by increasing the likelihood of high-intensity fires (fig. 17). Due to increased levels of competition, unnaturally dense populations of woody plants also may be more susceptible to drought, insect infestations, or other disturbances/stressors. Whether mortality of woody dominants is triggered by fire or some other factor, the sudden pulse of resource availability and release from competitive suppression could enable rapid expansion of existing exotic-species populations. If the population expansion is sufficient to cause a persistent increase in the abundance and continuity of surface fuels, a self-maintaining fire-exotic species cycle could be initiated. This type of transition may be a concern in parks such as Bandelier NM where the early $21^{\text {st }}$ century drought has triggered near-complete mortality in unnaturally dense piñon stands. 


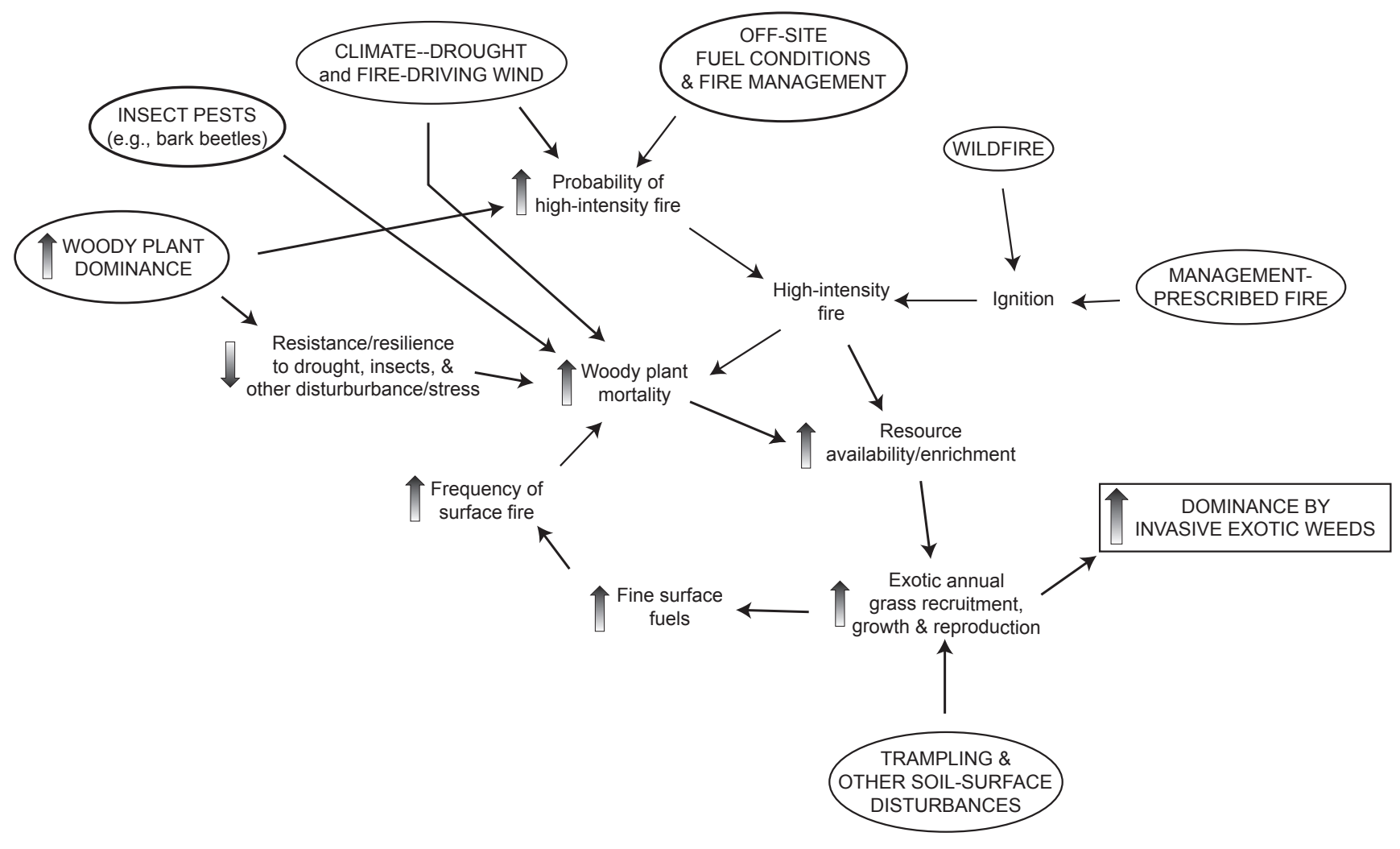

Figure 17. Conceptual model illustrating processes by which increasing woody-plant dominance, soil-surface disturbances, insect pests, climate, off-site fuel/fire conditions, wildfire, and management-prescribed fire interactively can lead to increasing dominance (and site conversion) by exotic annual grasses.

\section{Transition 7-Soil Erosion/Redistribution}

Severe erosion (transition to state $E$ in fig. 9) may be more likely in ecosystems dominated by exotic annual plants than in ecosystems dominated by perennial species because of greater fluctuations in annual ground cover in relation to climate (figs. 18 and 19). Greater soil exposure to erosive forces during unfavorable climatic periods could trigger spiraling processes of degradation as soil losses cause decreased ground cover and even greater soil exposure to erosive forces. Examples of soil erosion in annualized ecosystems can be found in Arches NP (fig. 20) and Canyonlands NP.

\section{Ecosystem Susceptibility to Change}

As discussed previously, there is much variability among dryland ecosystems in their susceptibility to transitions depicted in figure 9. Transition susceptibility varies as a function of (1) ecosystem exposure to driving processes, and (2) ecosystem resistance and resilience to driving processes. Depending on the goals and objectives of a long-term monitoring program, factors affecting ecosystem exposure, resistance, and resilience may play a role in spatial and temporal aspects of the monitoring design.

\section{Ecosystem Exposure}

Ecosystem exposure to drivers of change - particularly those considered to be anthropogenic stressors-is an important factor influencing ecosystem susceptibility to change beyond the range of conditions represented by the reference state. For example, sites exposed to frequent soil-surface disturbances or excessive herbivory by large mammals will be more susceptible to transitions affected by those processes than sites that are not so exposed, all else being equal. Landscape configuration also must be considered when evaluating ecosystem exposure where stressors may be associated with ecological 


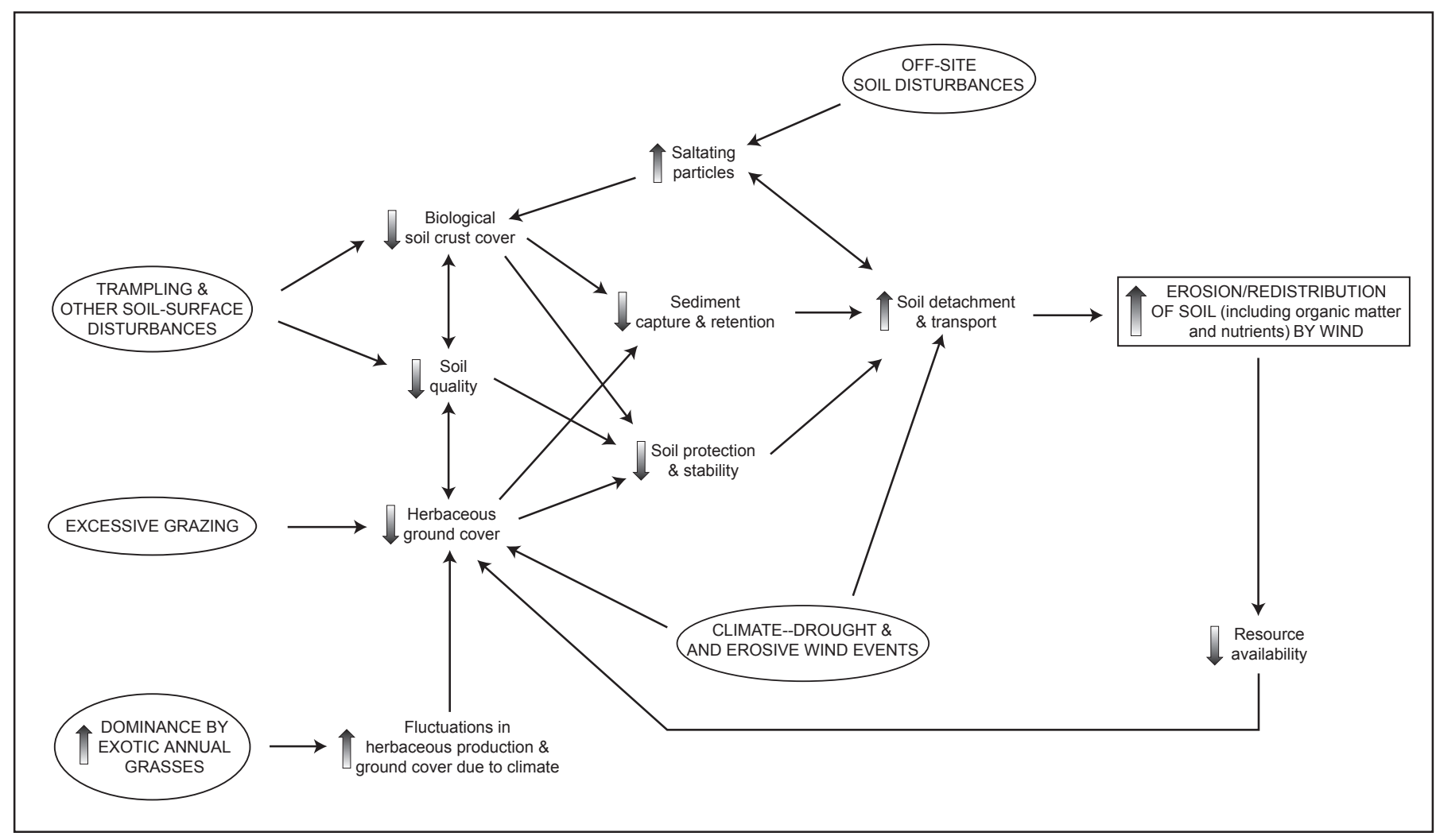

Figure 18. Conceptual model illustrating processes by which increasing site dominance by exotic annual grasses, excessive grazing, soil-surface disturbances, off-site soil-surface disturbances, and climate interactively can lead to accelerated erosion/redistribution of soil resources by wind.

flows from connected landscape units (fig. 8). At a regional scale, there is variation in ecosystem exposure to climatic factors (for example, erosive, high-intensity precipitation events) that affect the probability of transitions caused by erosional processes (fig. 6). Ecosystem exposure is not a static property. It can change with changes in climate and atmospheric conditions, landscape configuration, management, magnitude of existing stressors, or emergence of novel stressors.

\section{Ecosystem Resistance and Resilience}

Persistent transitions to degraded states occur when ecosystem properties that confer resistance and resilience are damaged or otherwise exceeded (Archer and Stokes, 2000; Tongway and Hindley, 2000; Stringham and others, 2003). Ecosystem resistance and resilience are not static and can change in relation to varying climatic conditions and dynamic ecosystem properties affected by climate, land use, and management (Scheffer and others, 2001; Scheffer and Carpenter, 2003). Some aspects of resistance and resilience also are strongly controlled by ecosystem properties that are relatively stable through time. Examples of these inherent ecosystem properties include landscape position and soil characteristics such as rock content, texture, mineralogy, profile development, and depth (for example, fig. 13).

A generalized description of factors affecting the resistance and resilience of dryland ecosystems is presented in appendix table C. Although generalizations can be useful, detailed considerations of resistance, resilience, and other aspects of system stability require that the variable of interest, benchmark conditions, spatial scale, temporal scale, and disturbance characteristics be clearly identified on a site-specific basis (Grimm and Wissel, 1997). Details matter-for example, the effects of soil properties on plant resistance and resilience to drought may vary with drought characteristics and among plant species in relation to particular ecophysiological traits.

\section{Implications for Ecosystem Classification}

Given the importance of ecosystem resistance and resilience in affecting probabilities of ecosystem change beyond the range of natural variability, an ideal ecosystem classification system to support ecosystem management and monitoring would be based on stable properties that influence ecosystem resistance and resilience. From the preceding discussion and appendix table $\mathrm{C}$, general factors that most strongly affect resistance and resilience are climatic conditions, soil structure, 


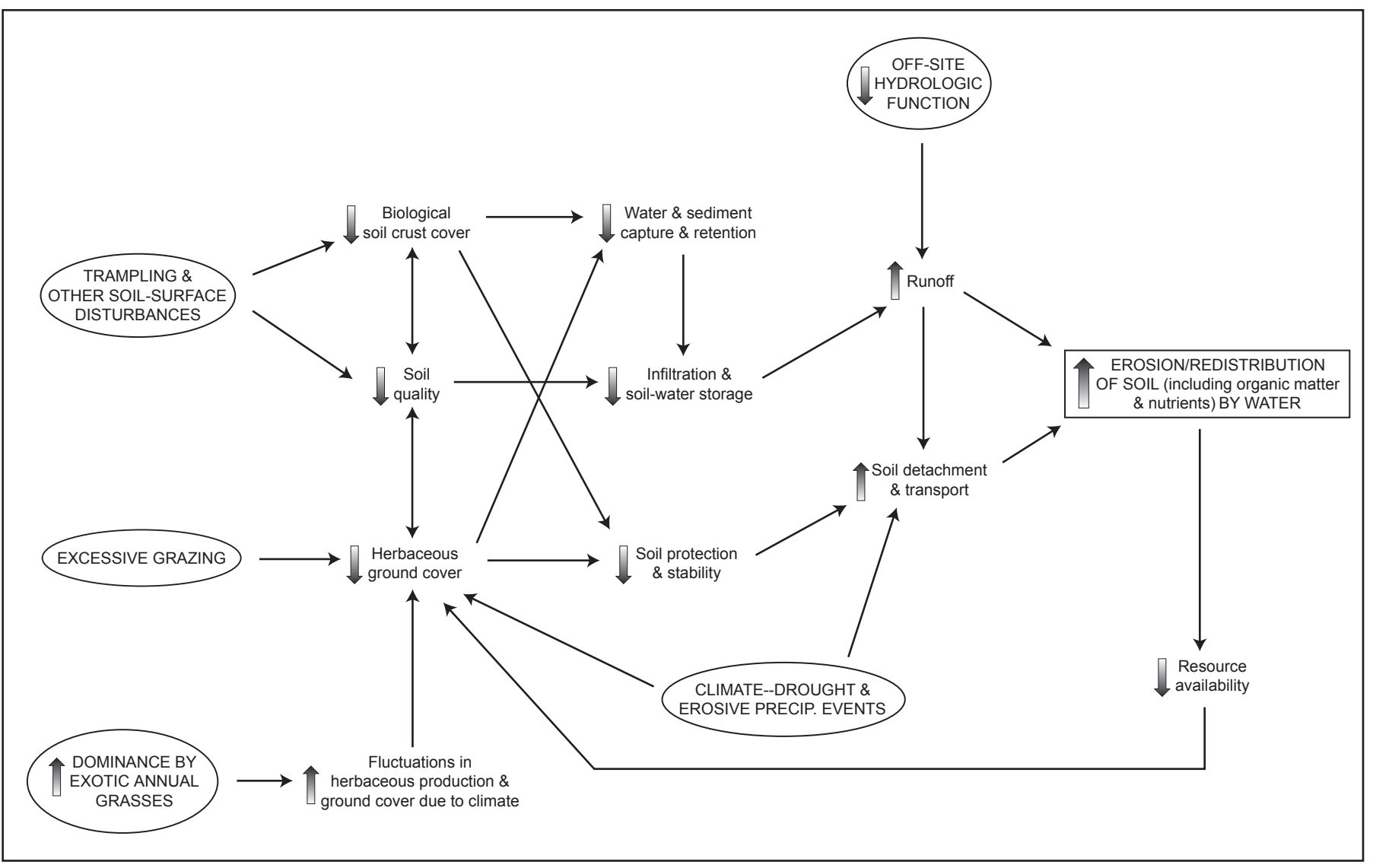

Figure 19. Conceptual model illustrating processes by which increasing site dominance by exotic annual grasses, grazing, soil-surface disturbances, off-site hydrologic function, and climate interactively can lead to accelerated erosion/redistribution of soil resources by water.

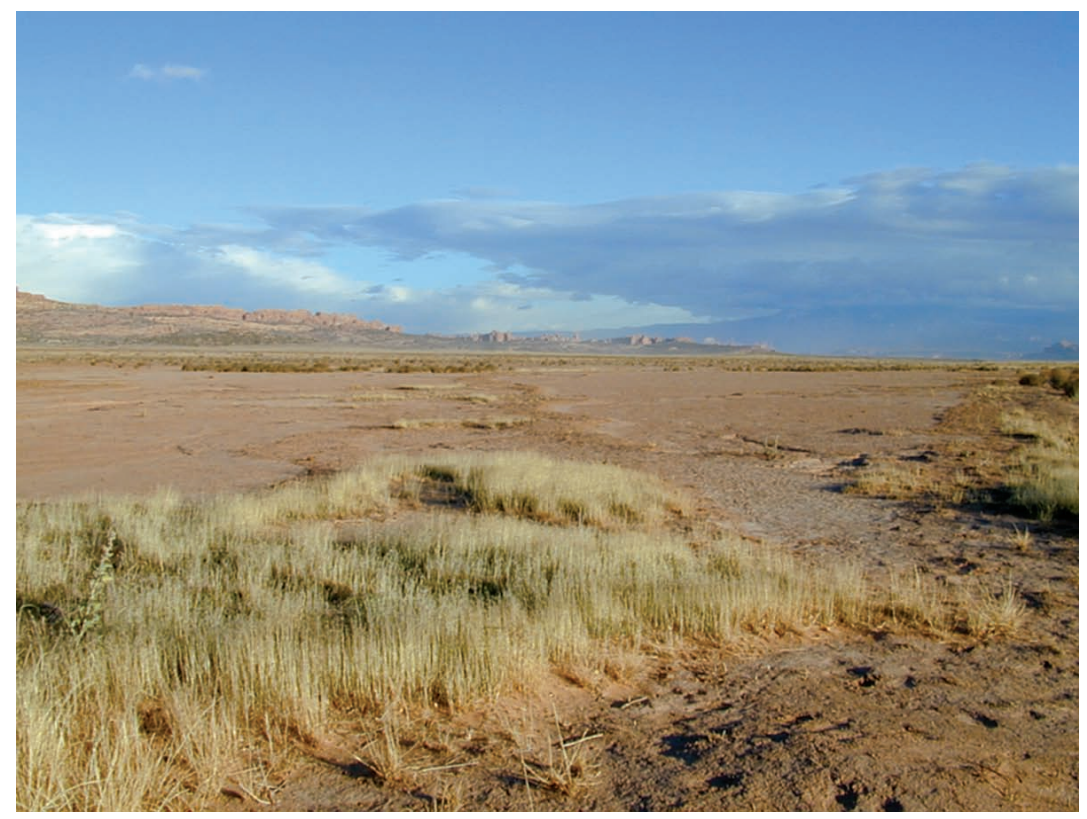

Figure 20. Example of an annualized ecosystem at Arches National Park where climate-driven fluctuations in ground cover and persistent soil instability likely contribute to accelerated rates of wind erosion. Photograph by Mark Miller, USGS. 
vegetation structure, and inherent ecosystem properties described by substrate characteristics and landscape setting. Although climatic conditions themselves are not stable, latitude, elevation, and aspect are three invariant factors that are certain to affect climatic conditions irrespective of future global climate change. To support ecosystem management and monitoring, it is therefore recommended that ecosystems be classified in relation to invariant climatic zones, substrate characteristics, and landscape setting rather than by the current composition of biotic communities.

For dryland ecosystems, the most widely used classification scheme based on general climatic zones and inherent site properties is the ecological site system of the U.S. Department of Agriculture Natural Resources Conservation Service (USDA NRCS). In this classification system, an ecological site is defined as a kind of land with specific physical characteristics which differs from other kinds of land in its ability to produce distinctive kinds and amounts of vegetation and in its response to management (Society for Range Management Task Group on Unity in Concepts and Terminology 1995, p. 279; Creque and others, 1999). Soil surveys produced by NRCS match soil series with ecological sites, and many ecological site descriptions are available on-line. ${ }^{12}$ These descriptions provide basic information on dynamics of soils and plant communities, and NRCS staff and cooperators currently are developing site-specific conceptual models that incorporate hypotheses regarding ecosystem resistance, resilience, and non-linear (threshold) responses in relation to land use and climate (USDA Natural Resources Conservation Service, 2003; Bestelmeyer and others, 2003, 2004). Challenges in the application of this scheme to planning, implementation, and interpretation of long-term monitoring may include lack of recent soil/ecological site mapping (older data may be less complete or accurate than recent data), complex map units (more than one soil series and ecological site per map unit), and inconsistent ecological site classifications across political boundaries. Alternative approaches to the classification of ecological land units for purposes of assessment and monitoring are provided by Bourgeron and others (2001a, b).

\section{Conclusion}

This report presents a literature review and a series of ecological conceptual models intended to inform policymakers and researchers in the selection of environmental attributes for long-term monitoring of dryland ecosystems of the Colorado Plateau. Climate and atmospheric conditions, soil-resource characteristics, major biotic functional groups, and typical natural disturbance regimes are reviewed because of their significance for ecosystem structure, functioning, and sustainability (Chapin and others, 1996). A generalized conceptual model describes (1) functional relationships among

\footnotetext{
${ }^{12}$ See the Electronic Field Office Technical Guide at http://www. nrcs.usda.gov/technical/efotg/.
}

key structural components of dryland ecosystems; (2) effects of climate, natural disturbances, and anthropogenic stressors on the functioning of selected ecosystem processes; and (3) how these drivers of ecosystem change can interact to produce particular patterns of ecosystem dynamics. Because a common goal of long-term monitoring is to provide managers with information needed to help sustain the health or integrity of ecosystems, additional models emphasize common processes and pathways of dryland degradation. Although developed to support the identification of long-term monitoring needs in NPS units, information in this report is broadly applicable well beyond NPS management boundaries and should be of use to other organizations or persons involved in management, conservation, and monitoring of dryland ecosystems in the Colorado Plateau or bordering ecoregions.

\section{References}

Aguiar, M.R., and Sala, O.E., 1999, Patch structure, dynamics and implications for the functioning of arid ecosystems: Trends in Ecology \& Evolution, v. 14, no. 7, p. 273-277.

Allen, C.D., 1989, Changes in the landscape of the Jemez Mountains, New Mexico, Ph.D. Dissertation: Berkeley, University of California, $346 \mathrm{p}$.

Allen, C.D., 1996, Elk response to the La Mesa Fire and current status in the Jemez Mountains, in Allen, C.D., ed., Fire effects in Southwestern Forests: Proceedings of the Second La Mesa Fire Symposium, Los Alamos, NM, March 29-31, 1994: Fort Collins, CO, U.S. Department of Agriculture, Forest Service, Rocky Mountain Forest and Range Experiment Station, General Technical Report RM-GTR-286, p. 179-195.

Allen, E.B., and Allen, M.F., 1990, The mediation of competition by mycorrhizae in successional and patchy environments, in Grace, J.B., and Tilman, D., eds., Perspectives on plant competition: San Diego, CA, Academic Press, p. 367-389.

Allen, C.D., and Breshears, D.D., 1998, Drought-induced shift of a forest-woodland ecotone: rapid landscape response to climate variation: Proceedings of the National Academy of Science U.S.A., v. 95, no. 25, p. 14839-14842.

Alward, R.D., Detling, J.K., and Milchunas, D.G., 1999, Grassland vegetation changes and nocturnal global warming: Science, v. 283, no. 5399, p. 229-231.

Amundson, R.G., and Jenny, Hans, 1991, The place of humans in the state factor theory of ecosystems and their soils: Soil Science, v. 151, p. 99-109.

Archer, S.A., 1994, Woody plant encroachment into southwestern grasslands and savannas: Rates, patterns and 
proximate causes, in Vavra, Martin, Laycock, W.A., and Pieper, R.D., eds., Ecological implications of livestock herbivory in the west: Denver, CO, Society for Range Management, p. 13-68.

Archer, S.A., and Bowman, Alison, 2002, Understanding and managing rangeland plant communities, in Grice, A.C., and Hodgkinson, K.C., eds., Global rangelands: Progress and prospects: Wallingford, UK, CABI Publishing, p. 63-80.

Archer, S.A., Schimel, D.S., and Holland, E.A., 1995, Mechanisms of shrubland expansion: Land use, climate or $\mathrm{CO}_{2}$ : Climatic Change, v. 29, p. 91-99.

Archer, S.A., and Smeins, F.E., 1991, Ecosystem-level processes, in Heitschmidt, R.K., and Stuth, J.W., eds., Grazing management: An ecological perspective: Portland, Timber Press, p. 109-139.

Archer, S.A., and Stokes, Chris, 2000, Stress, disturbance and change in rangeland ecosystems, in Arnalds, Ólafur, and Archer, S.A., eds., Rangeland desertification: Dordrecht, The Netherlands, Kluwer Academic Publishers, p. 17-38.

Asner, G.P., Archer, S.A., Hughes, R.F., Ansley, R.J., and Wessman, C.A., 2003, Net changes in regional woody vegetation cover and carbon storage in Texas drylands, 19371999: Global Change Biology, v. 9, no. 3, p. 316-335.

Asner, G.P., Seastedt, T.R., and Townsend, A.R., 1997, The decoupling of terrestrial carbon and nitrogen cycles: BioScience, v. 47, no. 4, p. 226-234.

Austin, A.T., Yahdjian, Laura, Stark, J.M., Belnap, Jayne, Porporato, Amilcare, Norton, Urszula, Ravetta, D.A., and Schaeffer, S.M., 2004, Water pulses and biogeochemical cycles in arid and semiarid ecosystems: Oecologia, v. 141, p. 221-235.

Bailey, R.G., 1995, Description of the ecoregions of the United States (2d ed.): Washington, D.C., U.S. Department of Agriculture, Forest Service, Miscellaneous Publication 1391, p. 108, 1 map sheet, scale 1:7,500,000.

Baker, D.D., and Schwintzer, C.R., 1990, Introduction, in Schwintzer, C.R., and Tjepkema, J.D., eds., The biology of Frankia and actinorhizal plants: San Diego, CA, Academic Press, p. 1-13.

Baker, W.L., and Shinneman, D.J., 2004, Fire and restoration of piñon-juniper woodlands in the western United States: A review: Forest Ecology and Management, v. 189, no. 1-3, p. $1-21$.

Barber, S.A., 1995, Soil nutrient bioavailability: A mechanistic approach: New York, John Wiley \& Sons, 414 p.

Bardgett, R.D., and Wardle, D.A., 2003, Herbivore-mediated linkages between aboveground and belowground communities: Ecology, v. 84, no. 9, p. 2258-2268.
Bartolome, J.W., 1993, Application of herbivore optimization theory to rangelands of the western United States: Ecological Applications, v. 3, no. 1, p. 27-29.

Belnap, Jayne, 2003a, Comparative structure of physical and biological soil crusts, in Belnap, Jayne, and Lange, O.L., eds., Biological soil crusts: Structure, function, and management (2d ed.), Ecological studies series 150: Berlin, Springer-Verlag, p. 177-191.

Belnap, Jayne, 2003b, Microbes and microfauna associated with biological soil crusts, in Belnap, Jayne, and Lange, O.L., eds., Biological soil crusts: Structure, function, and management ( $2 \mathrm{~d}$ ed.), Ecological studies series 150: Berlin, Springer-Verlag, p. 167-174.

Belnap, Jayne, 2002, Nitrogen fixation in biological soil crusts from southeast Utah, U.S.A.: Biology and Fertility of Soils, v. 35 , p. $128-135$.

Belnap, Jayne, Büdel, Burkhard, and Lange, O.L., 2003, Biological soil crusts: Characteristics and distribution, in Belnap, Jayne, and Lange, O.L., eds., Biological soil crusts: Structure, function, and management (2d ed.), Ecological studies series 150: Berlin, Springer-Verlag, p. 3-30.

Belnap, Jayne, and Gillette, D.A., 1998, Vulnerability of desert biological crusts to wind erosion: The influences of crust development, soil texture, and disturbance: Journal of Arid Environments, v. 39, p. 133-142.

Belnap, Jayne, and Lange, O.L., eds., 2003, Biological soil crusts: Structure, function, and management ( $2 \mathrm{~d}$ ed.), Ecological studies series 150: Berlin, Springer-Verlag, v. 150, $503 \mathrm{p}$.

Belnap, Jayne, and Phillips, S.L., 2001, Soil biota in an ungrazed grassland: response to annual grass (Bromus tectorum) invasion: Ecological Applications, v. 11, p. $1261-1275$.

Belnap, Jayne, Prasse, Rüdiger, and Harper, K.T., 2003, Influence of biological soil crusts on soil environments and vascular plants, in Belnap, Jayne, and Lange, O.L., eds., Biological soil crusts: Structure, function, and management (2d ed.), Ecological studies series 150: Berlin, SpringerVerlag, p. 281-300.

Belsky, A.J., 1986, Does herbivory benefit plants? A review of the evidence: The American Naturalist, v. 127, p. 870-892.

Belsky, A.J., 1987, The effects of grazing: Confounding of ecosystem, community, and organism scales: The American Naturalist, v. 129, p. 777-783.

Bestelmeyer, B.T., Brown, J.R., Havstad, K.M., Alexander, Robert, Chavez, George, and Herrick, J.E., 2003, Development and use of state-and-transition models for rangelands: Journal of Range Management, v. 56, p. 114-126. 
Bestelmeyer, B.T., Herrick, J.E., Brown, J.R., Trujillo, D.A., and Havstad, K.M., 2004, Land management in the American Southwest: A state-and-transition approach to ecosystem complexity: Environmental Management, v. 34, no. 1, p. $38-51$.

Betancourt, J.L., Pierson, E.A., Rylander, K.A., Fairchild-Parks, J.A., and Dean, J.S., 1993, Influence of history and climate on New Mexico piñon-juniper woodlands, in Aldon, E.F., and Shaw, D.W., eds., Managing piñonjuniper ecosystems for sustainability and social needs. U.S. Department of Agriculture, Forest Service: Fort Collins, Colorado, Rocky Mountain Research Station, General Technical Report RM-236, p. 42-62.

Betancourt, J.L., and Van Devender, T.R., 1981, Holocene vegetation in Chaco Canyon, New Mexico: Science, v. 214, p. 656-658.

Bethlenfalvay, G.J., and Dakessian, Suren, 1984, Grazing effects on mycorrhizal colonization and floristic composition of the vegetation on a semiarid range in northern Nevada: Journal of Range Management, v. 37, p. 312-316.

Bever, J.D., Westover, K.M., and Antonovics, Janis, 1997, Incorporating the soil community into plant population dynamics: the utility of the feedback approach: Journal of Ecology, v. 85, p. 561-573.

Bich, B.S., Butler, J.L., and Schmidt, C.A., 1995, Effects of differential livestock use on key plant species and rodent populations within selected Oryzopsis hymenoides/Hilaria jamesii communities of Glen Canyon National Recreation Area: The Southwestern Naturalist, v. 40, p. 281-287.

Billings, W.D., 1990, Bromus tectorum, a biotic cause of ecosystem impoverishment in the Great Basin, in Woodwell, G.M., ed., The earth in transition: Patterns and processes of biotic impoverishment: Cambridge, Cambridge University Press, p. 301-322.

Birkeland, P.W., 1999, Soils and geomorphology (3d ed.): New York, Oxford, 430 p.

Blank, R.R., Allen, Fay, and Young, J.A., 1994a, Extractable anions in soils following wildfire in a sagebrush-grass community: Soil Science Society of America Journal, v. 58, p. 564-570.

Blank, R.R., Allen, Fay, and Young, J.A., 1994b, Growth and elemental content of several sagebrush-steppe species in unburned and post-wildfire soil and plant effects on soil attributes: Plant and Soil, v. 164, p. 35-41.

Bock, C.E., Bock, J.H., Jepson, K.L., and Ortega, J.C., 1986, Ecological effects of planting African lovegrasses in Arizona: National Geographic Research, v. 2, no. 4, p. $456-463$.
Bourgeron, P.S., Humphries, H.C., and Jensen, M.E., 2001a, Ecosystem characterization and ecological assessments, in Jensen, M.E., and Bourgeron, P.S., eds., A guidebook for integrated ecological assessments: New York, SpringerVerlag, p. 40-54.

Bourgeron, P.S., Humphries, H.C., and Jensen, M.E., 2001b, Elements of ecological land classifications for ecological assessments, in Jensen, M.E., and Bourgeron, P.S., eds., A guidebook for integrated ecological assessments: New York, Springer-Verlag, p. 321-337.

Bowker, M.A., Reed, S.C., Belnap, Jayne, and Phillips, S.L., 2002, Temporal variation in community composition, pigmentation, and Fv/Fm of desert cyanobacterial soil crusts: Microbial Ecology, v. 43, p. 13-25.

Breshears, D.D., and Allen, C.D., 2002, The importance of rapid, disturbance-induced losses in carbon management and sequestration: Global Ecology \& Biogeography, v. 11, p. $1-5$.

Breshears, D.D., Rich, P.M., Barnes, F.J., and Campbell, Katherine, 1997, Overstory-imposed heterogeneity in solar radiation and soil moisture in a semiarid woodland: Ecological Applications, v. 7, p. 1201-1215.

Breshears, D.D., Whicker, J.J., Johansen, M.P., and Pinder III, J.E., 2003, Wind and water erosion and transport in semi-arid shrubland, grassland and forest ecosystems: Quantifying dominance of horizontal wind-driven transport: Earth Surface Processes and Landforms, v. 28, p. 1189-1209.

Briske, D.D., 1991, Developmental morphology and physiology of grasses, in Heitschmidt, R.K., and Stuth, J.W., eds., Grazing management: An ecological perspective: Portland, OR, Timber Press, p. 85-108.

Briske, D.D., Fuhlendorf, S.D., and Smeins, F.E., 2003, Vegetation dynamics on rangelands: A critique of the current paradigms: Journal of Applied Ecology, v. 40, no. 4, p. 601-614.

Briske, D.D., and Richards, J.H., 1994, Physiological responses of individual plants to grazing: Current status and ecological significance, in Vavra, Martin., Laycock, W.A., and Pieper, R.D., eds., Ecological implications of livestock herbivory in the west: Denver, CO, Society for Range Management, p. 147-176.

Briske, D.D., and Richards, J.H., 1995, Plant responses to defoliation: A physiological, morphological, and demographic evaluation, in Bedunah, D.J., and Sosebee, R.E., eds., Wildland plants: Physiological ecology and developmental morphology: Denver, CO, Society for Range Management, p. 635-710.

Brooks, M.L., D’Antonio, C.M., Richardson, D.M., Grace, J.B., Keeley, J.E., DiTomaso, J.M., Hobbs, R.J., Pellant, 
Mike, and Pyke, D.A., 2004, Effects of invasive alien plants on fire regimes: BioScience, v. 54, no. 7, p. 677-688.

Brotherson, J.D., Evenson, W.E., Rushforth, S.R., Fairchild, John, and Johansen, J.R., 1985, Spatial patterns of plant communities and differential weathering in Navajo National Monument, Arizona: The Great Basin Naturalist, v. 45 , p. $1-13$.

Brown, D.E., ed., 1982, Biotic communities of the American Southwest-United States and Mexico: Desert Plants, v. 4, no. $1-4$, p. 1-342.

Brown, J.H., and Heske, E.J., 1990, Control of a desert-grassland transition by a keystone rodent guild: Science, v. 250, p. 1705-1707.

Búrquez-Montijo, Alberto, Miller, M.E., and MartínezYrízar, Angelina, 2002, Mexican grasslands, thornscrub, and the transformation of the Sonoran Desert by invasive exotic buffelgrass, in Tellman, Barbara, ed., Invasive exotic species in the Sonoran region: Tucson, AZ, University of Arizona Press and Sonoran Desert Museum, p. 126-146.

Caldwell, M.M., Richards, J.H., Manwaring, J.H., and Eissenstat, D.M., 1987, Rapid shifts in phosphate acquisition show direct competition between neighboring plants: Nature, v. 327 , p. $615-616$.

Cayan, D.R., Redmond, K.T., and Riddle, L.G., 1999, ENSO and hydrologic extremes in the western United States: Journal of Climate, v. 12, p. 2881-2893.

Chambers, J.C., Vander Wall, S.B., and Schupp, E.W., 1999, Seed and seedling ecology of pinyon and juniper species in the pygmy woodlands of western North America: The Botanical Review, v. 65, p. 1-38.

Chapin III, F.S., 1991, Effects of multiple environmental stresses on nutrient availability and use by plants, in Mooney, H.A., Winner, W.E., and Pell, E.J., eds., Responses of plants to multiple stresses: San Diego, CA, Academic Press, p. 67-88.

Chapin III, F.S., 1993, Functional role of growth forms in ecosystem and global processes, in Ehleringer, J.R., and Field, C.B., eds., Scaling physiological processes: Leaf to globe: San Diego, CA, Academic Press, p. 287-312.

Chapin III, F.S., Torn, M.S., and Tateno, Masaki, 1996, Principles of ecosystem sustainability: The American Naturalist, v. 148 , no. 6 , p. 1016-1037.

Charley, J.L., and West, N.E., 1975, Plant-induced soil chemical patterns in some shrub-dominated semi-desert ecosystems of Utah: Journal of Ecology, v. 63, p. 945-963.

Christensen, N.L., Bartuska, A.M., Brown, J.H., Carpenter, S., D’Antonio, C.M., Francis, R., Franklin, J.F., MacMahon,
J.A., Noss, R.F., Parsons, D.J., Peterson, C.H., Turner, M.G., and Woodmansee, R.G., 1996, The report of the Ecological Society of America Committee on the scientific basis for ecosystem management: Ecological Applications, v. 6 , no. 3 , p. 665-691.

Clark, J.S., 1991, Disturbance and population structure on the shifting mosaic landscape: Ecology, v. 72, no. 3, p. 1119-1137.

Cole, D.N., 1990, Trampling disturbance and recovery of cryptogamic soil crusts in Grand Canyon National Park: Great Basin Naturalist, v. 50, no. 4, p. 321-325.

Coleman, D.C., and Crossley Jr., D.A., 1996, Fundamentals of soil ecology: San Diego, CA, Academic Press, 205 p.

Comer, Patrick, Faber-Langendoen, Don, Evans, R.A., Gawler, Sue, Josse, Carmen, Kittel, Gwen, Menard, Shannon, Pyne, Milo, Reid, Marion, Schulz, K.L., Snow, Kristin, Teague, Judy, 2003, Ecological systems of the United States: A working classification of U.S. terrestrial systems: Arlington, VA, NatureServe, 75 p.

Comstock, J.P., and Ehleringer, J.R., 1992, Plant adaptation in the Great Basin and Colorado Plateau: The Great Basin Naturalist, v. 52, no. 3, p. 195-215.

Connelly, J.W., Knick, S.T., Schroeder, M.A., and Stiver, S.J., 2004, Conservation assessment of greater sagegrouse and sagebrush habitats, unpublished report: Cheyenne, WY, Western Association of Fish and Wildlife Agencies.

Cooper, C.F., 1960, Changes in vegetation, structure, and growth of southwestern pine forests since white settlement: Ecological Monographs, v. 30, no. 2, p. 129-164.

Costanza, Robert, Mageau, Michael, Norton, Bryan, and Patten, B.C., 1998, What is sustainability?, in Rapport, D.J., Costanza, Robert, Epstein, P.R., Gaudet, Claude, and Levins, Richard, eds., Ecosystem health: Malden, MA, Blackwell Science, p. 231-239.

Crawley, M.J., 1983, Herbivory: The dynamics of animalplant interactions: Berkeley, CA, University of California Press, $437 \mathrm{p}$.

Crawley, M.J., 1987, What makes a community invasible?, in Gray, A.J., Crawley, M.J., and Edwards, P.J., eds., Colonization, succession, and stability: Oxford, Blackwell Scientific Publications, p. 429-453.

Crawley, M.J., 1997, Plant-herbivore dynamics, in Crawley, M.J., ed., Plant ecology (2d ed.): Oxford, Blackwell Science, p. $401-474$.

Creque, J.A., Bassett, S.D., and West, N.E., 1999, Viewpoint: Delineating ecological sites: Journal of Range Management, v. 52 , no. 6 , p. 546-549. 
Currie, D.J., 2001, Projected effects of climate change on patterns of vertebrate and tree species richness in the conterminous United States: Ecosystems, v. 4, no. 3, p. 216-225.

Dale, V.H., Brown, Sandra, Haeuber, R.A., Hobbs, N.T., Huntly, Nancy, Naiman, R.J., Riebsame, W.E., Turner, M.G., and Valone, T.J., 2000, Ecological principles and guidelines for managing the use of land: Ecological Applications, v. 10, no. 3, p. 639-670.

Daniels, R.B., and Hammer, R.D., 1992, Soil geomorphology: New York, John Wiley \& Sons, 236 p.

D’Antonio, C.M., and Vitousek, P.M., 1992, Biological invasions by exotic grasses, the grass/fire cycle, and global change: Annual Review of Ecology and Systematics, v. 23, p. 63-87.

Davenport, D.W., Breshears, D.D., Wilcox, B.P., and Allen, C.D., 1998, Viewpoint: Sustainability of pinyon-juniper ecosystems - a unifying perspective of soil erosion thresholds: Journal of Range Management, v. 51, p. 231-240.

Davis, M.A., Grime, J.P., and Thompson, Ken, 2000, Fluctuating resources in plant communities: A general theory of invasibility: Journal of Ecology, v. 88, no. 3, p. 528-534.

DeAngelis, D.L., and Huston, M.A., 1993, Further considerations on the debate over herbivore optimization theory: Ecological Applications, v. 3, no. 1, p. 30-31.

Díaz, Sandra, Briske, D.D., and McIntyre, Sue, 2002, Range management and plant functional types, in Grice, A.C., and Hodgkinson, K.C., eds., Global rangelands: Progress and prospects: Wallingford, UK, CABI Publishing, p. 81-100.

Díaz, Sandra, and Cabido, Marcelo, 2001, Vive la différence: Plant functional diversity matters to ecosystem processes: Trends in Ecology \& Evolution, v. 16, no. 11, p. 646-655.

Dick-Peddie, W.A., 1993, New Mexico vegetation: past, present, and future: Albuquerque, NM, University of New Mexico Press, 244 p.

Dobrowolski, J.D., 1994, In situ estimation of effective hydraulic conductivity to improve erosion modeling for rangeland conditions, in Blackburn, W.H., Pierson, F.B., Schuman, G.E., and Zartman, R., eds., Variability in rangeland water erosion processes: Madison, WI, Soil Science Society of America, p. 83-91.

Dukes, J.S., and Mooney, H.A., 1999, Does global change increase the success of biological invaders?: Trends in Ecology and Evolution, v. 14, no. 4, p. 135-139.

Dwyer, D.D., and Pieper, R.D., 1967, Fire effects on blue grama-pinyon-juniper rangeland in New Mexico: Journal of Range Management, v. 20, p. 359-362.

Dyer, M.I., Turner, C.L., and Seastedt, T.R., 1993, Herbivory and its consequences: Ecological Applications, v. 3, no. 1, p. 10-16.
Ehleringer, J.R., Schwinning, Susan, Gebauer, R.L., 1999. Water use in arid land ecosystems, pages 347-365, in M. C. Press (ed.), Advances in Plant Physiological Ecology, Blackwell Science, Oxford.

Eisenhart, K.S., 2004, Historic range of variability of piñonjuniper woodlands on the Uncompahgre Plateau, western Colorado: Final report to the Western Area Power Administration: Boulder, $\mathrm{CO}, 86 \mathrm{p}$.

Evans, R.D., and Belnap, Jayne, 1999, Long-term consequences of disturbance on nitrogen dynamics in an arid ecosystem: Ecology, v. 80, no. 1, p. 150-160.

Evans, R.D., and Ehleringer, J.R., 1993, A break in the nitrogen cycle in aridlands? Evidence from $\delta^{15} \mathrm{~N}$ of soils: Oecologia, v. 94, p. 314-317.

Evans, R.D., and Lange, O.L., 2003, Biological soil crusts and ecosystem nitrogen and carbon dynamics, in Belnap, Jayne, and Lange, O.L., eds., Biological soil crusts: Structure, function, and management ( $2 \mathrm{~d}$ ed.), Ecological studies series 150: Berlin, Springer-Verlag, p. 263-279.

Evans, R.D., Rimer, Rhonda, Sperry, Linda, and Belnap, Jayne, 2001, Exotic plant invasion alters nitrogen dynamics in an arid grassland: Ecological Applications, v. 11, no. 5, p. 1301-1310.

Evenden, Angela, Miller, M.E., Beer, Margaret, Nance, Elizabeth, Daw, Sonya, Wight, Aneth, Estenson, Mike, Cudlip, Lynn, 2002, Northern Colorado Plateau vital signs network and prototype cluster plan for natural resources monitoring: Phase I report: Moab, UT, National Park Service, Northern Colorado Plateau Network, 138 p. plus appendices.

Fenn, M.E., Baron, J.S., Allen, E.B., Rueth, H.M., Nydick, K.R., Geiser, Linda, Bowman, W.D., Sickman, J.O., Meixner, Thomas, Johnson, D.W., and Neitlich, Peter, 2003, Ecological effects of nitrogen deposition in the western United States: BioScience, v. 53, no. 4, p. 404-420.

Fenn, M.E., Haeuber, R.A., Tonnesen, G.S., Baron, J.S., Grossman-Clarke, Susanne, Hope, Diane, Jaffe, D.A., Copeland, Scott, Geiser, Linda, Rueth, H.M., and Sickman, J.O., 2003, Nitrogen emissions, deposition, and monitoring in the western United States: BioScience, v. 53, no. 4, p. 391-403.

Floyd, M.L., Colyer, Marilyn, Hanna, D.D., and Romme, W.H., 2003, Gnarly old trees: Canopy characteristics of old-growth piñon-juniper woodlands, in Floyd, M.L., ed., Ancient piñon-juniper woodlands: A natural history of Mesa Verde country: Boulder, CO, University Press of Colorado, p. 11-29.

Floyd, M.L., Hanna, D.D., and Romme, W.H., 2004, Historical and recent fire regimes in piñon-juniper woodlands on Mesa Verde, Colorado, U.S.A.: Forest Ecology and Management, v. 198, p. 269-289. 
Floyd, M.L., Romme, W.H., and Hanna, D.D., 2000, Fire history and vegetation pattern in Mesa Verde National Park, Colorado, U.S.A.: Ecological Applications, v. 10, no. 6, p. 1666-1680.

Floyd, M.L., Romme, W.H., and Hanna, D.D., 2003, Fire history, in Floyd, M.L., ed., Ancient piñon-juniper woodlands: A natural history of Mesa Verde country: Boulder, CO, University Press of Colorado, p. 261-277.

Friedel, M.H., Sparrow, A.D., Kinloch, J.E., and Tongway, D.J., 2003, Degradation and recovery processes in arid grazing lands of central Australia, part 2: Vegetation: Journal of Arid Environments, v. 55, no. 2, p. 327-348.

Galloway, J.N., Aber, J.D., Erisman, J.W., Seitzinger, S.P., Howarth, R.W., Cowling, E.B., and Cosby, B.J., 2003, The nitrogen cascade: BioScience, v. 53, no. 4, p. 341-356.

Grayson, D.K., 1994, The extinct late Pleistocene mammals of the Great Basin, in Harper, K.T., St. Clair, L.L., Thorne, K.H., and Hess, W.M., eds., Natural history of the Colorado Plateau and Great Basin: Niwot, CO, University Press of Colorado, p. 55-85.

Grimm, Volker, and Wissel, Christian, 1997, Babel, or the ecological stability discussions: An inventory and analysis of terminology and a guide for avoiding confusion: Oecologia, v. 109 , p. 323-334.

Griswold, Terry, Parker, F.D., and Tepedino, V.J., 1997, The bees of the San Rafael Desert: Implications for the bee fauna of the Grand Staircase-Escalante National Monument, in Hill, L.M., ed., Learning from the land: Grand StaircaseEscalante National Monument Science Symposium Proceedings, 1997: Denver, CO, U.S. Department of Interior, Bureau of Land Management, National Science and Technology Center, p. 175-186.

Groves, C.R., Jensen, D.B., Valutis, L.L., Redford, K.H., Shaffer, M.L., Scott, J.M., Baumgartner, J.V., Higgins, J.V., Beck, M.W., and Anderson, M.G., 2002, Planning for biodiversity conservation: Putting conservation science into practice: BioScience, v. 52, no. 6, p. 499-512.

Grubb, P.J., 1977, The maintenance of species richness in plant communities: The importance of the regeneration niche: Biological Review, v. 52, no. 2, p. 107-145.

Hanna, D.D., and Graham, T.B., 2003, Reptiles and amphibians of the piñon-juniper woodlands, in Floyd, M.L., ed., Ancient piñon-juniper woodlands: A natural history of Mesa Verde country: Boulder, CO, University Press of Colorado, p. 151-165.

Hannah, L., Midgley, G.F., Lovejoy, Tom, Bond, W.J., Bush, Mark, Lovett, J.C., Scott, David, and Woodward, F.I., 2002, Conservation of biodiversity in a changing climate: Conservation Biology, v. 16, no. 1, p. 264-268.
Harper, J.L., 1977, Population biology of plants: San Diego, CA, Academic Press, 892 p.

Harper, K.T., and Belnap, Jayne, 2001, The influence of biological soil crusts on mineral uptake by associated vascular plants: Journal of Arid Environments, v. 47, no. 3, p. 347-357.

Harper, K.T., Sanderson, S.C., and McArthur, E.D., 2003, Pinyon-juniper woodlands in Zion National Park, Utah: Western North American Naturalist, v. 63, no. 2, p. 189-202.

Harris, T.A., Asner, G.P., and Miller, M.E., 2003, Changes in vegetation structure after long-term grazing in pinyon-juniper ecosystems: Integrating imaging spectroscopy and field studies: Ecosystems, v. 6, no. 4, p. 368-383.

Havstad, K.M., Herrick, J.E., and Schlesinger, W.H., 2000, Desert rangelands, degradation and nutrients, in Arnalds, Ólafur, and Archer, S.A., eds., Rangeland desertification: Dordrecht, The Netherlands, Kluwer Academic Publishers, p. 77-87.

Hereford, Richard, and Webb, R.H., 1992, Historic variation of warm-season rainfall, southern Colorado Plateau, Southwestern U.S.A.: Climatic Change, v. 22, no. 3, p. 239-256.

Hereford, Richard, Webb, R.H., and Graham, Scott, 2002, Precipitation history of the Colorado Plateau Region, 1900-2000, USGS Fact Sheet 119-02: U.S. Department of Interior, U.S. Geological Survey, 4. p.

Herrick, J.E., Brown, J.R., Tugel, A.J., Shaver, P.L., and Havstad, K.M., 2002, Application of soil quality to monitoring and management: Paradigms from rangeland ecology: Agronomy Journal, v. 94, no. 1, p. 3-11.

Herrick, J.E., and Whitford, W.G., 1995, Assessing the quality of rangeland soils: Challenges and opportunities: Journal of Soil and Water Conservation, v. 50, no. 3, p. 237-242.

Higgins, R.W., Mo, K.C., and Yao, Yin, 1998, Interannual variability of the United States summer precipitation regime: Journal of Climate, v. 11, no. 10, p. 2582-2606.

Hillel, Daniel, 1998, Environmental soil physics: San Diego, CA, Academic Press, 771 p.

Hobbs, R.J., 1991, Disturbance as a precursor to weed invasion in native vegetation: Plant Protection Quarterly, v. 6, p. 99-104.

Hobbs, R.J., and Norton, D.A., 1996, Towards a conceptual framework for restoration ecology: Restoration Ecology, v. 4, no. 2, p. 93-110.

Holechek, J.L., Gomes, Hilton, Molinar, Francisco, Galt, Dee, and Valdez, Raul, 2000, Short-duration grazing: The facts in 1999: Rangelands, v. 22, no. 1, p. 18-22. 
Holling, C.S., 1996, Surprise for science, resilience for ecosystems, and incentives for people: Ecological Applications, v. 6 , no. 3, p. 733-735.

Hooper, D.U., and Johnson, Loretta, 1999, Nitrogen limitation in dryland ecosystems: Responses to geographical and temporal variation in precipitation: Biogeochemistry, v. 46, no. 1, p. 247-293.

Houghton, J.T., Ding, Yihui, Griggs, D.J., Noguer, Maria, van der Linden, P.J., Dai, Xiaosu, Maskell, K., and Johnson, C.A., eds., 2001, Climate change 2001: The scientific basis, Contribution of working group 1 to the third assessment report of the intergovernmental panel on climate change: Cambridge, Cambridge University Press, 881 p.

Howell, Wendy, 1998, Germination and establishment of Bromus tectorum L. in relation to cation exchange capacity, seedbed, litter, soil cover and water: Prescott, AZ, Prescott College, $83 \mathrm{p}$.

Hunt, C.B., 1974, Natural regions of the United States and Canada: San Francisco, CA, W.H. Freeman, 725 p.

Jacobs, B.F., and Gatewood, R.G., 1999, Restoration studies in degraded pinyon-juniper woodlands of north-central New Mexico, in Monsen, S.B., and Stevens, R.J., eds., Proceedings: Ecology and management of pinyon-juniper communities within the interior West, September 15-18, 1997, Provo, UT, Proc. RMRS-P-9: Ogden, UT, U.S. Department of Agriculture, Forest Service, Rocky Mountain Research Station, p. 294-298.

James, J.J., Tiller, R.L., and Richards, J.H., 2005, Multiple resources limit plant growth and function in a saline-alkaline desert community: Journal of Ecology, v. 93, p. 113-126.

Jameson, D.A., 1962, Effects of burning on a galleta-black grama range invaded by juniper: Ecology, v. 43, no. 4, p. 760-763.

Jenny, Hans, 1941, Factors of soil formation: A system of quantitative pedology: New York, McGraw-Hill, 281 p.

Jenny, Hans, 1980, The soil resource: Origin and behavior: New York, Springer-Verlag, 377 p.

Johansen, M.P., Hakonson, T.E., and Breshears, D.D., 2001, Post-fire runoff and erosion from rainfall simulation: Contrasting forests with shrublands and grasslands: Hydrological Processes, v. 15, no. 15, p. 2953-2965.

Johnsen, T.N., Jr., 1962, One-seed juniper invasion of northern Arizona grasslands: Ecological Monographs, v. 32, no. 3, p. 187-207.

Johnstone, I.M., 1986, Plant invasion windows: A time-based classification of invasion potential: Biological Review, v. 61, p. 369-394.
Karlen, D.L., Mausbach, M.J., Doran, J.W., Cline, R.G., Harris, R.F., and Schuman, G.E., 1997, Soil quality: A concept, definition, and framework for evaluation: Soil Science Society of America Journal, v. 61, p. 4-10.

Koniak, Susan, 1985, Succession in pinyon-juniper woodlands following wildfire in the Great Basin: Great Basin Naturalist, v. 45 , no. 3 , p. 556-566.

Kruse, W.H., and Perry, H.M., 1995, Ecosystem management research in an "old-growth" piñon-juniper woodland, in Shaw, D.W., Aldon, E.F., and LoSapio, Carol, eds., Desired future conditions for piñon-juniper ecosystems, 8-12 August1994, Flagstaff, AZ, General Technical Report RM-258: Fort Collins, CO, U.S. Department of Agriculture, Forest Service, Rocky Mountain Forest and Range Experiment Station, p. 219-224.

Küchler, A.W., 1964, Potential natural vegetation of the conterminous United States: A map and manual. American Geographical Society Special Publication No. 36: Princeton, NJ, Princeton Polychrome Press, 116 p.

Landres, P.B., Morgan, Penelope, and Swanson, F.J., 1999, Overview of the use of natural variability concepts in managing ecological systems: Ecological Applications, v. 9, no. 4, p. 1175-1188.

Lange, O.L., 2003, Photosynthesis of soil-crust biota as dependent on environmental factors, in Belnap, Jayne, and Lange, O.L., eds., Biological soil crusts: Structure, function, and management ( $2 \mathrm{~d}$ ed.): Berlin, Springer-Verlag, Ecological studies series, p. 217-240.

Larcher, Walter, 1995, Physiological plant ecology (3d ed.): Berlin, Springer-Verlag, $506 \mathrm{p}$.

Lauenroth, W.K., and Sala, O.E., 1992, Long-term forage production of North American shortgrass steppe: Ecological Applications, v. 2, no. 4, p. 397-403.

Lavelle, Patrick, 1997, Faunal activities and soil processes: Adaptive strategies that determine ecosystem function: Advances in Ecological Research, v. 27, p. 93-132.

Leatherman, D.A., and Kondratieff, B.C., 2003, Insects associated with the piñon-juniper woodlands of Mesa Verde country, in Floyd, M.L., ed., Ancient piñon-juniper woodlands: A natural history of Mesa Verde country: Boulder, CO, University Press of Colorado, p. 167-180.

Levine, J.M., and D'Antonio, C.M., 1999, Elton revisited: A review of evidence linking diversity and invasibility: Oikos, v. 87 , no. 1 , p. $15-26$.

Likens, Gene, 1992, An ecosystem approach: Its use and abuse, Excellence in ecology, Book 3: Oldendorf/Luhe, Germany, Ecology Institute, 166 p. 
Logan, J.A., Régnière, Jacque, and Powell, J.A., 2003, Assessing the impacts of global warming on forest pest dynamics: Frontiers in Ecology and the Environment, v. 1, no. 3 , p. $130-137$.

Loik, M.E., Breshears, D.D., Lauenroth, W.K., and Belnap, Jayne, 2004, A multi-scale perspective of water pulses in dryland ecosystems: Climatology and ecohydrology of the western U.S.A.: Oecologia, v. 141, p. 269-281.

Ludwig, J.A., and Tongway, D.J., 1997, A landscape approach to rangeland ecology, in Ludwig, J.A., Tongway, D.J., Freudenberger, David, Noble, Jim, and Hodgkinson, Ken, eds., Landscape ecology, function and management: Principles from Australia's rangelands: Collingwood, VIC, Australia, CSIRO Publishing, p. 1-12.

Ludwig, J.A., and Tongway, D.J., 2000, Viewing rangelands as landscape systems, in Arnalds, Ólafur, and Archer, S.A., eds., Rangeland desertification: Dordrecht, The Netherlands, Kluwer Academic Publishers, p. 39-52.

MacDonald, L.H., and Huffman, E.L., 2004, Post-fire soil water repellency: Persistence and soil moisture thresholds: Soil Science Society of America Journal, v. 68, p. 1729-1734.

Mack, M.N., and D'Antonio, C.M., 1998, Impacts of biological invasions on disturbance regimes: Trends in Ecology and Evolution, v. 13, no. 5, p. 195-198.

Mack, R.N., and Thompson, J.N., 1982, Evolution in steppe with few large, hoofed mammals: American Naturalist, v. 119 , no. 6 , p. 757-773.

Mantua, N.J., and Hare, S.R., 2002, The Pacific decadal oscillation: Journal of Oceanography, v. 58, no. 1, p. 35-42.

Marler, M.J., Zabinski, C.A., and Callaway, R.M., 1999, Mycorrhizae indirectly enhance competitive effects of an invasive forb on a native bunchgrass: Ecology, v. 80, no. 4, p. $1180-1186$.

Marschner, Horst, 1995, Mineral nutrition of higher plants (2d ed.): London, Academic Press, 889 p.

McAuliffe, J.R., 2003, The interface between precipitation and vegetation: The importance of soils in arid and semi-arid environments, in Weltzin, J.F., and McPherson, G.R., eds., Changing precipitation regimes and terrestrial ecosystems: A North American perspective: Tucson, AZ, University of Arizona Press, p. 9-27.

McCabe, G.J., Palecki, M.A., and Betancourt, J.L., 2004, Pacific and Atlantic Ocean influences on multidecadal drought frequency in the United States: Proceedings of the National Academy of Sciences, v. 101, no. 12, p. 4136-4141.

McLaughlin, S.P., 1986, Floristic analysis of the southwestern United States: Great Basin Naturalist, v. 46, no. 1, p. 46-65.
McLaughlin, S.P., 1989, Natural floristic areas of the western United States: Journal of Biogeography, v. 16, p. 239-248.

McNaughton, S.J., 1983, Compensatory plant growth as a response to herbivory: Oikos, v. 40, p. 329-336.

McNaughton, S.J., 1986, On plants and herbivores: The American Naturalist, v. 128, p. 765-770.

McNaughton, S.J., 1993, Grasses and grazers, science and management: Ecological Applications, v. 3, no. 1, p. 17-20.

Mead, J.I., Sharpe, S.E., and Agenbroad, L.D., 1991, Holocene bison from Arches National Park, southeastern Utah: Great Basin Naturalist, v. 51, p. 336-342.

Miller, M.E., 1999, Use of historic aerial photography to study vegetation change in the Negrito Creek watershed, southwestern New Mexico: Southwestern Naturalist, v. 44, no. 2, p. 121-137.

Miller, M.E., Belnap, Jayne, Beatty, Susan, and Webb, Bruce, 2001, Components of spatial and temporal soil variation at Canyonlands National Park: Implications for P dynamics and cheatgrass (Bromus tectorum) performance, in McArthur, E.D., and Fairbanks, D.J., eds., Shrubland ecosystem genetics and biodiversity: Proceedings, June 13-15, 2000, Provo, UT, Proc. RMRS-P-21: Ogden, UT, U.S. Department of Agriculture, Forest Service, Rocky Mountain Research Station, p. 154-162.

Miller, M.E., Sharrow, Dave, and Cudlip, Lynn, 2003, Northern Colorado Plateau vital signs network and prototype cluster plan for natural resources monitoring: Phase II report: Moab, UT, National Park Service, Northern Colorado Plateau Network, 111 p. plus appendices.

Miller, R.F., Rose, J.A., Svejcar, T.J., Bates, J., and Paintner, Kara, 1995, Western juniper woodlands: 100 years of plant succession, in Shaw, D.W., Aldon, E.F., and LoSapio, Carol, ed., Desired future conditions for piñon-juniper ecosystems, August 8-12, 1994, Flagstaff, AZ, General Technical Report RM-258: Fort Collins, CO, U.S. Department of Agriculture, Forest Service, Rocky Mountain Forest and Range Experiment Station, p. 5-8.

Miller, R.F., Svejcar, T.J., and West, N.E., 1994, Implications of livestock grazing in the intermountain sagebrush region: Plant composition, in Vavra, Martin, Laycock, W.A., and Pieper, R.D., eds., Ecological implications of livestock herbivory in the west: Denver, CO, Society for Range Management, p. 101-146.

Miller, R.F., and Tausch, R.J., 2001, The role of fire in juniper and pinyon woodlands: a descriptive analysis, in Galley, K.E.M., and Wilson, T.P., eds., Proceedings of Fire Conference 2000: The First National Congress on Fire, Ecology, Prevention and Management, Invasive Species Workshop: The role of fire in the control and spread of invasive species, 
28 November-1 December, 2000, San Diego, CA, Miscellaneous Publication No. 13: Tallahassee, FL, Tall Timbers Research Station, p. 15-30.

Miller, R.F., Tausch, R.J., and Waichler, W.S., 1999, Oldgrowth juniper and pinyon woodlands, in Monsen, S.B., and Stevens, R.J., eds., Proceedings: Ecology and management of pinyon-juniper communities within the Interior West; September 15-18, 1997, Provo, UT, Proc. RMRS-P-9 Ogden, UT, U.S. Department of Agriculture, Forest Service, Rocky Mountain Research Station, p. 375-384.

Mitchell, V.L., 1976, The regionalization of climate in the western United States: Journal of Applied Meteorology, v. 15, no. 9, p. 920-927.

Mooney, H.A., and Hofgaard, Annika, 1999, Biological invasions and global change, in Sandlund, O.T., Schei, P.J., and Viken, Aslaug, eds., Invasive species and biodiversity management: Dordrecht, The Netherlands, Kluwer Academic Publishers, p. 139-148.

NatureServe, 2003, Ecological systems database, version 1.01: Arlington, VA, NatureServe.

Neff, J.C., Reynolds, R.L., Belnap, Jayne, and Lamothe, Paul, 2005, Multi-decadal impacts of grazing on soil physical and biogeochemical properties in southeast Utah: Ecological Applications, v. 15, no. 1, p. 87-95.

Nelson, C.R., 1994, Insects of the Great Basin and Colorado Plateau, in Harper, K.T., St. Clair, L.L., Thorne, K.H., and Hess, W.M., eds., Natural history of the Colorado Plateau and Great Basin: Niwot, CO, University Press of Colorado, p. 211-237.

Noon, B.R., 2003, Conceptual issues in monitoring ecological systems, in Busch, D.E., and Trexler, J.C., eds., Monitoring ecosystems: Interdisciplinary approaches for evaluating ecoregional initiatives: Washington, D.C., Island Press, p. 27-71.

Norfleet, M.L., Ditzler, C.A., Puckett, W.E., Grossman, R.B., and Shaw, J.N., 2003, Soil quality and its relationship to pedology: Soil Science, v. 168, no. 3, p. 149-155.

Norton, J.B., Sandor, J.A., and White, C.S., 2003, Hillslope soils and organic matter dynamics within a native American agroecosystem on the Colorado Plateau: Soil Science Society of America Journal, v. 67, no. 1, p. 225-234.

Noy-Meir, Immanuel, 1973, Desert ecosystems: Environment and producers: Annual Review of Ecology and Systematics, v. 4 , p. $25-51$.

Oesterheld, Martin, Loreti, Juan, and Sala, O.E., 2001, Inter-annual variation in primary production of a semi-arid grassland related to previous-year production: Journal of Vegetation Science, v. 12, p. 137-142.
Okin, G.S., Murray, B.C., and Schlesinger, W.H., 2001, Degradation of sandy arid shrubland environments: Observations, process modeling, and management implications: Journal of Arid Environments, v. 47, no. 2, p. 123-144.

Painter, E.L., and Belsky, A.J., 1993, Application of herbivore optimization theory to rangelands of the western United States: Ecological Applications, v. 3, no. 1, p. 2-9.

Peters, D.C., Pielke, R.A., Sr., Bestelmeyer, B.T., Allen, C.D., Munson-McGee, Stuart, and Havstad, K.M., 2004, Crossscale interactions, nonlinearities, and forecasting catastrophic events: Proceedings of the National Academy of Sciences, v. 101, no. 42, p. 15130-15135.

Peters, R.S., Waller, D.M., Noon, B.R., Pickett, S.T.A., Murphy, Dennis, Cracraft, Joel, Kiester, Ross, Kuhlmann, Walter, Houck, Oliver, and Snape, W.J., III, 1997, Standard scientific procedures for implementing ecosystem management on public lands, in Pickett, S.T.A., Ostfeld, R.S., Shachak, Moshe, and Likens, G.E., eds., The ecological basis of conservation: Heterogeneity, ecosystems, and biodiversity: New York, Chapman \& Hall, p. $320-336$.

Peterson, K.L., 1994, Modern and Pleistocene climatic patterns in the West, in Harper, K.T., St. Clair, L.L., Thorne, K.H., and Hess, W.M., eds., Natural history of the Colorado Plateau and Great Basin: Niwot, CO, University Press of Colorado, p. 27-53.

Pickett, S.T.A., and Thompson, J.N., 1978, Patch dynamics and the design of nature reserves: Biological Conservation, v. 13 , p. $27-37$.

Polley, H.W., Johnson, H.B., Mayeux, H.S., and Tischler, C.R., 1996, Are some of the recent changes in grassland communities a response to rising $\mathrm{CO}_{2}$ concentrations?, in Körner, Christian, and Bazzaz, F.A., eds., Carbon dioxide, populations, and communities: San Diego, CA, Academic Press, p. 177-195.

Polley, H.W., Mayeux, H.S., Johnson, H.B., and Tischler, C.R., 1997, Viewpoint: Atmospheric $\mathrm{CO}_{2}$, soil water, and shrub/grass ratios on rangelands: Journal of Range Management, v. 50, p. 278-284.

Raison, R.J., 1979, Modification of the soil environment by vegetation fires, with particular reference to nitrogen transformations: A review: Plant and Soil, v. 51, p. 73-108.

Rapport, D.J., 1998, Defining ecosystem health, in Rapport, D.J., Costanza, Robert, Epstein, P.R., Gaudet, C.L., and Levins, Richard, eds., Ecosystem health: Malden, MA, Blackwell Science, p. 18-33.

Rapport, D.J., and Whitford, W.G., 1999, How ecosystems respond to stress: Common properties of arid and aquatic systems: BioScience, v. 49, p. 193-203. 
Reeder, J.D., Schuman, G.E., Morgan, J.A., and LeCain, D.R., 2004, Response of organic and inorganic carbon and nitrogen to long-term grazing of the shortgrass steppe: Environmental Management, v. 33, no. 4, p. 485-495.

Reid, K.D., Wilcox, B.P., Breshears, D.D., and MacDonald, Lee, 1999, Runoff and erosion in a piñon-juniper woodland: Influence of vegetation patches: Soil Science Society of America Journal, v. 63, no. 6, p. 1869-1879.

Reiners, W.A., and Driese, K.L., 2001, The propagation of ecological influences through heterogeneous environmental space: BioScience, v. 51, no. 11, p. 939-950.

Reynolds, R.L., Belnap, Jayne, Reheis, Marith., Lamothe, Paul, and Luiszer, Fred., 2001, Aeolian dust in Colorado Plateau soils: Nutrient inputs and recent change in source: Proceedings of the National Academy of Sciences, v. 98, no. 13, p. $7123-7127$.

Reynolds, H.L., Packer, A.A., Bever, J.D., and Clay, Keith, 2003, Grassroots ecology: Plant-microbe-soil interactions as drivers of plant community structure and dynamics: Ecology, v. 84, no. 9, p. 2281-2291.

Romme, W.H., Floyd-Hanna, M.L., and Hanna, D.D., 2003, Ancient piñon-juniper forests of Mesa Verde and the West: A cautionary note for forest restoration programs, in Omi, P.N., and Joyce, L.A., eds., Fire, fuel treatments, and ecological restoration: Conference proceedings, April 16-18, 2002, Fort Collins, CO, Proc. RMRS-P-29: Fort Collins, CO, U.S. Department of Agriculture, Forest Service, Rocky Mountain Research Station, p. 335-350.

Romme, W.H., Oliva, Sylvia, and Floyd, M.L., 2003, Threats to the piñon-juniper woodlands, in Floyd, M.L., ed., Ancient piñon-juniper woodlands: A natural history of Mesa Verde country: Boulder, CO, University Press of Colorado, p. 339-360.

Rosentreter, Roger, and Belnap, Jayne, 2003, Biological soil crusts of North America, in Belnap, Jayne, and Lange, O.L., eds., Biological soil crusts: Structure, function, and management (2d ed.): Berlin, Springer-Verlag, Ecological studies series 150 , p. 31-50.

Rowlands, P.G., and Brian, N.J., 2001, Fishtail Mesa: A vegetation resurvey of a relict area in Grand Canyon National Park, Arizona: Western North American Naturalist, v. 61, no. 2, p. 159-181.

Sala, O.E., and Lauenroth, W.K., 1982, Small rainfall events: An ecological role in semiarid regions: Oecologia, v. 53, p. 301-304.

San Miguel, G.L., and Colyer, Marilyn, 2003, Mesa Verde country's woodland avian community, in Floyd, M.L., ed., Ancient piñon-juniper woodlands: A natural history of Mesa Verde country: Boulder, CO, University Press of Colorado, p. 89-110.
Savage, Melissa, 1991, Structural dynamics of a southwestern pine forest under chronic human influence: Annals of the Association of American Geographers, v. 81, p. 271-289.

Savory, Allan, 1988, Holistic resource management: Covelo, CA, Island Press, 558 p.

Savory, Allan, and Parsons, S.D., 1980, The Savory grazing method: Rangelands, v. 2, no. 6, p. 234-237.

Scheffer, Marten, and Carpenter, S.R., 2003, Catastrophic regime shifts in ecosystems: Linking theory to observation: Trends in Ecology \& Evolution, v. 18, no. 12, p. 648-656.

Scheffer, Marten., Carpenter, S.R., Foley, J.A., Folke, Carl, and Walker, Brian, 2001, Catastrophic shifts in ecosystems: Nature, v. 413, p. 591-596.

Schimel, D.S., Parton, W.J., Adamsen, P.J., Woodmansee, R.G., Senft, R.L., and Stillwell, M.A., 1986, The role of cattle in the volatile loss of nitrogen from shortgrass steppe: Biogeochemistry, v. 2, p. 39-52.

Schimel, D.S., Stillwell, M.A., and Woodmansee, R.G., 1985, Biogeochemistry of $\mathrm{C}, \mathrm{N}$, and $\mathrm{P}$ in a soil catena of the shortgrass steppe: Ecology, v. 66, no. 1, p. 276-282.

Schlesinger, W.H., 1997, Biogeochemistry: An analysis of global change (2d ed.): San Diego, CA, Academic Press, $588 \mathrm{p}$.

Schlesinger, W.H., Raikes, J.A., Hartley, A.E., and Cross, A.F., 1996, On the spatial pattern of soil nutrients in desert ecosystems: Ecology, v. 77, p. 364-374.

Schlesinger, W.H., Reynolds, J.F., Cunningham, G.L., Huenneke, L.F., Jarrell, W.M., Virginia, R.A., and Whitford, W.G., 1990, Biological feedbacks in global desertification: Science, v. 247, p. 1043-1048.

Schwencke, Jaime, and Carú, Margarita, 2001, Advances in actinorhizal symbiosis: host plant-Frankia interactions, biology, and applications in arid land reclamation. A review: Arid Land Research and Management, v. 15, no. 4, p. 285-328.

Seastedt, T.R., 2001, Soils, in Bowman, W.D., and Seastedt, T.R., eds., Structure and function of an alpine ecosystem: Niwot, CO: New York, Oxford University Press, p. $157-173$.

Segura, Gerardo, and Snook, L.C., 1992, Stand dynamics and regeneration patterns of a piñon pine forest in east central Mexico: Forest Ecology and Management, v. 47, p. 175-194.

Seybold, C.A., Herrick, J.E., and Brejda, J.J., 1999, Soil resilience: A fundamental component of soil quality: Soil Science, v. 164, no. 4, p. 224-234. 
Shafer, S.L., Bartlein, P.J., and Thompson, R.S., 2001, Potential changes in the distributions of western North America tree and shrub taxa under future climate scenarios: Ecosystems, v. 4, p. 200-215.

Skujins, J., 1984, Microbial ecology of desert soils: Advances in Microbial Ecology, v. 7, p. 49-91.

Smith, J.K., ed., 2000, Wildland fire in ecosystems: Effects of fire on fauna. General Technical Report RMRS-GTR-42 vol.1: Ogden, UT, U.S. Department of Agriculture, Forest Service, Rocky Mountain Research Station, 83 p.

Smith, S.D., Huxman, T.E., Zitzer, S.F., Charlet, T.N., Housman, D.C., Coleman, J.S., Fenstermaker, L.K., Seemann, J.R., and Nowak, R.S., 2000, Elevated $\mathrm{CO}_{2}$ increases productivity and invasive species success in an arid ecosystem: Nature, v. 408, no. 6808, p. 79-82.

Smith, S.E., and Read, D.J., 1997, Mycorrhizal symbiosis (2d ed.): San Diego, CA, Academic Press, 605 p.

Smith, T.M., Shugart, H.H., and Woodward, F.I., eds., 1997, Plant functional types: Their relevance to ecosystem properties and global change, International geosphere-biosphere programme book series, vol. 1: Cambridge, Cambridge University Press, 369 p.

Society for Range Management Task Group on Unity in Concepts and Terminology, 1995, New concepts for assessment of rangeland condition: Journal of Range Management, v. 48 , p. $271-282$.

Sousa, W.P., 1984, The role of disturbance in natural communities: Annual Review of Ecology and Systematics, v. 15, p. 353-391.

Spaeth, K.E., Thurow, T.L., Blackburn, T.H., and Pierson, F.B., 1996, Ecological dynamics and management effects on rangeland hydrologic processes, in Spaeth, K.E., Pierson, F.B., Weltz, M.A., and Hendricks, R.G., eds., Grazingland hydrology issues: Perspectives for the $21^{\text {st }}$ century: Denver, CO, Society for Range Management, p. 25-51.

Sparrow, A.D., Friedel, M.H., and Tongway, D.J., 2003, Degradation and recovery processes in arid grazing lands of central Australia, part 3: Implications at landscape scale: Journal of Arid Environments, v. 55, no. 2, p. 349-360.

Spence, J.R., 2001, Climate of the central Colorado Plateau, Utah and Arizona: Characterization and recent trends, in van Riper III, Charles, Thomas, K.A., and Stuart, M.A., eds., Proceedings of the fifth biennial conference of research on the Colorado Plateau. U.S. Geological Survey/ FRESC Report Series USGSFRESC/COPL/2001/24, p. 187-203.

Spence, J.R., Romme, W.H., Floyd-Hanna, M.L., and Rowlands, P.G., 1995, A preliminary vegetation classification for the Colorado Plateau, in van Riper III, Charles, ed.,
Proceedings of the Second Biennial Conference on Research in Colorado Plateau National Parks, 25-28 October 1993. National Park Service Transactions and Proceedings Series NPS/NRNAU/NRTP-95/11, p. 193-213.

Stohlgren, T.J., Binkley, Dan, Chong, G.W., Kalkhan, M.A., Schell, L.D., Bull, K.A., Otsuki, Yuka, Newman, Gregory, Bashkin, Michael, and Son, Yowhan, 1999, Exotic plant species invade hot spots of native plant diversity: Ecological Monographs, v. 69, no. 1, p. 25-46.

Stringham, T.K., Krueger, W.C., and Shaver, P.L., 2003, State and transition modeling: An ecological process approach: Journal of Range Management, v. 56, no. 2, p. 106-113.

Suding, K.N., Gross, K.L., and Houseman, G.R., 2004, Alternative states and positive feedbacks in restoration ecology: Trends in Ecology \& Evolution, v. 19, no. 1, p. 46-53.

Swetnam, T.W., and Betancourt, J.L., 1998, Mesoscale disturbance and ecological response to decadal climatic variability in the American Southwest: Journal of Climate, v. 11, p. $3128-3147$.

Sydoriak, C.A., Allen, C.D., and Jacobs, B.F., 2000, Would ecological landscape restoration make the Bandelier Wilderness more or less of a wilderness?, in Cole, D.N., McCool, S.F., Borrie, W.T., and O'Loughlin, J., eds., Wilderness science in a time of change conference, vol. 5: Wilderness ecosystems, threats, and management, May 23-27, 1999, Missoula, MT, Proc. RMRS-P-15-VOL-5: Ogden, UT, U.S. Department of Agriculture, Forest Service, Rocky Mountain Research Station, p. 209-215.

Tausch, R.J., and Nowak, R.S., 1999, Fifty years of ecotone change between shrub and tree dominance in the Jack Springs Pinyon Research Natural Area, in McArthur, E.D., Ostler, W.K., and Wambolt, C.L., eds., Proceedings: Shrubland ecotones, August 12-14, 1998, Ephraim, UT, Proc. RMRS-P-11: Ogden, UT, U.S. Department of Agriculture, Forest Service, Rocky Mountain Research Station, p. 1-7.

Tausch, R.J., and West, N.E., 1988, Differential establishment of pinyon and juniper following fire: The American Midland Naturalist, v. 119, no. 1, p. 174-184.

Tausch, R.J., West, N.E., and Nabi, A.A., 1981, Tree age and dominance patterns in Great Basin pinyon-juniper woodlands: Journal of Range Management, v. 34, no. 4, p. 259-264.

Thomas, Lisa, Whittier, Jodi, Tancreto, Nicole, Atkins, Julie, Miller, Mark, and Cully, Anne, 2003, Vital signs monitoring plan for the Southern Colorado Plateau Network: Phase I report: Flagstaff, AZ, National Park Service, Southern Colorado Plateau Network, 89 p. plus appendices. 
Thurow, T.L., 1991, Hydrology and erosion, in Heitschmidt, R.K., and Stuth, J.W., eds., Grazing management: An ecological perspective: Portland, OR, Timber Press, p. 141-159.

Tilman, David, Knops, Johannes, Wedin, David, Reich, Peter, Ritchie, Mark, and Siemann, Evan, 1997, The influence of functional diversity and composition on ecosystem processes: Science, v. 277, p. 1300-1302.

Tongway, D.J., and Hindley, N.L., 2000, Assessing and monitoring desertification with soil indicators, in Arnalds, Ólafur, and Archer, S.A., eds., Rangeland desertification: Dordrecht, The Netherlands, Kluwer Academic Publishers, p. 89-98.

Tongway, D.J., Sparrow, A.D., and Friedel, M.H., 2003, Degradation and recovery processes in arid grazing lands of central Australia, part 1: Soil and land resources: Journal of Arid Environments, v. 55, no. 2, p. 301-326.

Toy, T.J., Foster, G.R., and Renard., K.G., 2002, Soil erosion: Processes, prediction, measurement, and control: New York, John Wiley \& Sons, 352 p.

Trappe, J.M., 1981, Mycorrhizae and productivity of arid and semiarid rangelands, in Manassah, J.T., and Briskey, E.J., eds., Advances in food-producing systems for arid and semiarid lands: New York, Academic Press, p. 581-599.

Tress, J.A., and Klopatek, J.M., 1987, Successional changes in community structure of pinyon-juniper woodlands of north-central Arizona, in Everett, R.L., ed., Proceedings: Pinyon-juniper conference, January 13-16, 1986, Reno, NV, General Technical Report INT-215: Ogden, UT, U.S. Department of Agriculture, Forest Service, Intermountain Research Station, p. 80-85.

Truett, Joe, 1996, Bison and elk in the American Southwest: In search of the pristine: Environmental Management, v. 20, p. 195-206.

U.S. Department of Agriculture, Forest Service, 2003, Forest insect and disease conditions in the Southwestern Region: Albuquerque, NM, U.S. Department of Agriculture, Forest Service, Southwestern Region, Forestry and Forest Health, Publication No. R3-04-02, 34 p.

U.S. Department of Agriculture, Natural Resources Conservation Service, 2003, National range and pasture handbook: Washington, DC, U.S. Department of Agriculture, Natural Resources Conservation Service, Grazing Lands Technology Institute.

Van Auken, O.W., 2000, Shrub invasions of North American semiarid grasslands: Annual Review of Ecology and Systematics, v. 31, p. 197-215.

van der Heijden, M.G.A., Klironomos, J.N., Ursic, Margot, Moutoglis, Peter, Streitwolf-Engel, Ruth, Boller, Thomas, Wiemken, Andres, and Sanders, I.R., 1998, Mycorrhizal fungal diversity determines plant diversity, ecosystem variability, and productivity: Nature, v. 396, no. 6706, p. 69-72.

Vankat, J.L., 2004, Montane and subalpine terrestrial ecosystems of the southern Colorado Plateau: Literature review and conceptual models, Supplement I, in Thomas, Lisa, Lauver, Chris, Hendrie, Marguerite, Tancreto, Nicole, Whittier, Jodi, Atkins, Julie, Miller, M.E., and Cully, Anne, eds., Vital signs monitoring plan for the Southern Colorado Plateau Network, Phase II Report: Flagstaff, AZ, National Park Service, Southern Colorado Plateau Network.

Veblen, T.T., 2003, Key issues in fire regime research for fuels management and ecological restoration, in Omi, P.N., and Joyce, L.A., eds., Fire, fuel treatments, and ecological restoration: Conference proceedings, April 16-18, 2002, Fort Collins, CO, Proc. RMRS-P-29: Fort Collins, CO, U.S. Department of Agriculture, Forest Service, Rocky Mountain Research Station, p. 259-275.

Veblen, T.T., Hadley, K.S., Reid, M.S., and Rebertus, A.J., 1991, The response of subalpine forests to spruce beetle outbreak in Colorado: Ecology, v. 72, no. 1, p. 213-231.

Vitousek, P.M., 1990, Biological invasions and ecosystem processes: Towards an integration of population biology and ecosystem studies: Oikos, v. 57, no. 1, p. 7-13.

Vitousek, P.M., 1994a, Beyond global warming: Ecology and global change: Ecology, v. 75, no. 7, p. 1861-1876.

Vitousek, P.M., 1994b, Factors controlling ecosystem structure and function, in Amundson, R.G., Harden, J.W., and Singer, M.J., eds., Factors of soil formation: A fiftieth anniversary retrospective, SSSA Special Publication No. 33: Madison, WI, Soil Science Society of America, p. 87-97.

Waichler, W.S., Miller, R.F., and Doeschler, P.S., 2001, Community characteristics of old-growth western juniper woodlands: Journal of Range Management, v. 54, no. 5, p. 518-527.

Walker, B.H., 1993, Rangeland ecology: Understanding and managing change: Ambio, v. 22, no. 2-3, p. 80-87.

Walker, B.H., 1997, Functional types in non-equilibrium systems, in Smith, T.M., Shugart, H.H., and Woodward, F.I., eds., Plant functional types: Their relevance to ecosystem properties and global change: Cambridge, Cambridge University Press, p. 91-103.

Walker, B.H., Kinzig, A.P., and Langridge, J.L., 1999, Plant attribute diversity, resilience, and ecosystem function: The nature and significance of dominant and minor species: Ecosystems, v. 2, no. 2, p. 95-113.

Walker, L.R., and Chapin III, F.S., 1987, Interactions among processes controlling successional change: Oikos, v. 50, p. 131-135. 
Walther, G.R., Post, Eric, Convey, Peter, Menzel, Annette, Pearmesan, Camille, Beebee, T.J.C., Fromentin, J.M., Hoegh-Guldbert, Ove, and Bairlein, Franz, 2002, Ecological responses to recent climate change: Nature, v. 416, p. 389-395.

Wangler, M.J., and Minnich, R.A., 1996, Fire and succession in piñon-juniper woodlands of the San Bernardino Mountains, California: Madroño, v. 43, p. 493-514.

Wardle, D.A., 2002, Communities and ecosystems: Linking the aboveground and belowground components: Princeton, NJ, Princeton University Press, 392 p.

Warren, S.D., 2003, Synopsis: Influence of biological soil crusts on arid land hydrology and soil stability, in Belnap, Jayne, and Lange, O.L., eds., Biological soil crusts: Structure, function, and management ( $2 \mathrm{~d}$ ed.), Ecological studies series 150: Berlin, Springer-Verlag, p. 349-360.

Webb, R.H., McCabe, G.J., Hereford, Richard, and Wilkowske, C., 2004, Climatic fluctuations, drought, and flow in the Colorado River: U.S. Geological Survey Fact Sheet 3062-04, 4 p.

Weltzin, J.F., Loik, M.E., Schwinning, Susan, Williams, D.G., Fay, P.A., Haddad, B.M., Harte, John, Huxman, T.E., Knapp, A.K., Lin, Guanghui, Pockman, W.T., Shaw, M.R., Small, E.E., Smith, M.D., Smith, S.D., Tissue, D.T., and Zak, J.C., 2003, Assessing the response of terrestrial ecosystems to potential changes in precipitation: BioScience, v. 53 , no. 10 , p. 941-952.

West, N.E., 1991, Nutrient cycling in soils of semiarid and arid regions, in Skujins, J.J., ed., Semiarid lands and deserts: Soil resource and reclamation: New York, Marcel Dekker, Inc., p. 295-332.

West, N.E., 1999, Distribution, composition, and classification of current juniper-pinyon woodlands and savannas across western North America, in Monsen, S.B., and Stevens, R.J., eds., Sustaining and restoring a diverse ecosystem: Proceedings: Ecology and management of pinyon-juniper communities within the Interior West, September 15-18, 1997, Provo, UT, Proc. RMRS-P-9: Ogden, UT, U.S. Department of Agriculture, Forest Service, Rocky Mountain Research Station, p. 20-23.

West, N.E., and Young, J.A., 2000, Intermountain valleys and lower mountain slopes, in Barbour, M.G., and Billings, W.D., eds., North American terrestrial vegetation. (2d ed.): Cambridge, Cambridge Univesity Press, p. 255-284.

Westoby, Mark, Walker, Brian, and Noy-Meir, Immanuel, 1989, Range management on the basis of a model which does not seek to establish equilibrium: Journal of Arid Environments, v. 17, p. 235-239.

Whelan, R.J., 1995, The ecology of fire: Cambridge, Cambridge University Press, 346 p.
Whicker, J.J., Breshears, D.D., Wasiolek, P.T., Kirchner, T.B., Tavani, R.A., Schoep, D.A., and Rodgers, J.C., 2002, Temporal and spatial variation of episodic wind erosion in unburned and burned semiarid shrubland: Journal of Environmental Quality, v. 31, no. 2, p. 599-612.

Whisenant, S.G., 1999, Repairing damaged wildlands: A process-oriented, landscape-scale approach: Cambridge, Cambridge University Press, 312 p.

White, P.S., Harrod, John, Romme, W.H., and Betancourt, J.L., 1999, Disturbance and temporal dynamics, in Szaro, R.C., Johnson, N.C., Sexton, W.T., and Malk, A.J., eds., Ecological stewardship: A common reference for ecosystem management, Vol. II: Oxford, UK, Elsevier Science, Ltd., p. 566-584.

White, P.S., and Pickett, S.T.A., 1985, Natural disturbance and patch dynamics: An introduction, in Pickett, S.T.A., and White, P.S., eds., The ecology of natural disturbance and patch dynamics: San Diego, CA, Academic Press, p. 3-13.

White, P.S., and Walker, J.L., 1997, Approximating nature's variation: Selecting and using reference information in restoration ecology: Restoration Ecology, v. 5, no. 4, p. 338-349.

Whitford, W.G., 1996, The importance of the biodiversity of soil biota in arid ecosystems: Biodiversity and Conservation, v. 5, p. 185-195.

Whitford, W.G., 2002, Ecology of desert systems: San Diego, CA, Academic Press, 343 p.

Wiegand, Thorston, Snyman, H.A., Kellner, Klaus, and Paruelo, J.M., 2004, Do grasslands have a memory: Modeling phytomass production of a semiarid South African grassland: Ecosystems, v. 7, no. 3, p. 243-258.

Wiens, J.A., Van Horne, Beatrice, and Noon, B.R., 2002, Integrating landscape structure and scale into natural resource management, in Liu, Jianguo, and Taylor, W.W., eds., Integrating landscape ecology into natural resource management: Cambridge, Cambridge University Press, p. 23-67.

Wilcox, B.P., Breshears, D.D., and Allen, C.D., 2003, Ecohydrology of a resource-conserving semiarid woodland: Effects of scale and disturbance: Ecological Monographs, v. 73 , no. 2, p. 223-239.

Williams, J.D., Dobrowolski, J.P., Gillette, D.A., and West, N.E., 1995a, Microphytic crust influence on wind erosion: Transactions of the American Society of Agricultural Engineers, v. 38, p. 131-137.

Williams, J.D., Dobrowolski, J.P., and West, N.E., 1995b, Microphytic crust influence on interrill erosion and infiltration capacity: Transactions of the American Society of Agricultural Engineers, v. 38, p. 139-146. 
With, K.A., 2002, The landscape ecology of invasive spread: Conservation Biology, v. 16, p. 1192-1203.

Woodmansee, R.G., 1979, Factors influencing input and output of nitrogen in grasslands, in French, N.R., ed., Perspectives in grassland ecology: New York, Springer-Verlag, p. 117-134.

Wright, H.A., 1980, The role and use of fire in the semidesert grass-shrub type: Ogden, UT, U.S. Department of Agriculture, Forest Service, Intermountain Forest and Range Experiment Station, General Technical Report INT-85, 24 p. 
Appendix 
Appendix Table A. Primary functions and attributes/measures associated with components of dryland ecosystems. Components are organized in relation to the four interactive controls of ecosystem structure and function.

\begin{tabular}{|c|c|c|c|c|}
\hline $\begin{array}{l}\text { INTERACTIVE } \\
\text { CONTROLS* }^{*}\end{array}$ & \multicolumn{2}{|c|}{ COMPONENTS/PROCESSES } & PRIMARY ECOSYSTEM FUNCTIONS & ATTRIBUTES/MEASURES \\
\hline \multirow{5}{*}{$\begin{array}{l}\text { Regional } \\
\text { climatic and } \\
\text { atmospheric } \\
\text { conditions }\end{array}$} & \multicolumn{2}{|c|}{ Precipitation } & $\begin{array}{l}\text { Water inputs; drives water-limited ecosystem and population } \\
\text { processes (for example, nutrient cycling, } \mathrm{C} \text { and } \mathrm{N} \text { fixation, seed } \\
\text { germination); erosive force for detachment, entrainment, and } \\
\text { overland redistribution and export of soil, litter, and propagules; } \\
\text { drives fire disturbances due to effects of interannual variability on } \\
\text { fuel production and flammability; strongly affects ecosystem } \\
\text { resistance and resilience to natural disturbances and anthropogenic } \\
\text { stressors. }\end{array}$ & $\begin{array}{l}\text { Seasonality, quantity, intensity (amount per event and } \\
\text { per unit time), duration, temporal frequency, temporal } \\
\text { variability (among seasons, within seasons, among } \\
\text { years), spatial variability, form (rain vs. snow). } \\
\text { Frequency, intensity, and duration of erosion-driving } \\
\text { events. }\end{array}$ \\
\hline & \multicolumn{2}{|l|}{ Wind } & $\begin{array}{l}\text { Drives the redistribution and export (transfer among patches and } \\
\text { among systems) of soil, litter, and propagules; affects ecosystem- } \\
\text { atmosphere gas-exchange }\left(\mathrm{CO}_{2} \text { intake and evapotranspiration); }\right. \\
\text { energy-balance modification (transfer of sensible and latent heat). }\end{array}$ & $\begin{array}{l}\text { Average sustained and peak velocities and direction } \\
\text { (and frequency-magnitude distributions of these by } \\
\text { season), seasonal and diurnal variability, spatial } \\
\text { variability. Frequency, intensity, and duration of } \\
\text { erosion-driving events. }\end{array}$ \\
\hline & \multicolumn{2}{|c|}{ Radiant energy } & $\begin{array}{l}\text { Energy inputs for photosynthesis and sensible heat; effects on } \\
\text { ecosystem-atmosphere gas-exchange }\left(\mathrm{CO}_{2} \text { uptake and }\right. \\
\text { evapotranspiration) and energy balance; interacts with precipitation } \\
\text { to affect resource availability and drive biotic processes through } \\
\text { effects on timing and rate of metabolic activity. }\end{array}$ & $\begin{array}{l}\text { Maximum, minimum, and average values by season } \\
\text { (heat), spectral characteristics, intensity, temporal } \\
\text { variability (seasonal and diurnal), spatial variability } \\
\text { (horizontally and vertically). }\end{array}$ \\
\hline & \multicolumn{2}{|c|}{$\mathrm{N}_{2}$ and $\mathrm{CO}_{2}$} & Nitrogen and carbon inputs (gaseous). & Atmospheric concentration. \\
\hline & \multicolumn{2}{|c|}{ Dust \& other airborne constituents } & Mineral nutrient inputs. & $\begin{array}{l}\text { Quantity, chemical composition, temporal distribution } \\
\text { (seasonality), spatial distribution. }\end{array}$ \\
\hline \multirow{4}{*}{$\begin{array}{l}\text { Disturbance } \\
\text { regime }\end{array}$} & \multirow{4}{*}{$\begin{array}{l}\text { Episodic } \\
\text { climatic } \\
\text { events }\end{array}$} & Drought & $\begin{array}{l}\text { Drives change in ecosystem structure and function (1) by altering } \\
\text { competitive relations and inducing selective, potentially widespread } \\
\text { mortality - resulting in persistent dominance shifts among } \\
\text { vegetative functional groups; and (2) by affecting ecosystem } \\
\text { resistance/resilience to other natural disturbances (for example, } \\
\text { extreme precipitation events, wind storms, insect outbreaks, and/or } \\
\text { fire) and anthropogenic stressors. }\end{array}$ & $\begin{array}{l}\text { Seasonality, intensity, duration, frequency, extent, } \\
\text { timing in relation to extreme precipitation and wind } \\
\text { events. }\end{array}$ \\
\hline & & $\begin{array}{l}\text { Extreme precipitation } \\
\text { events/floods }\end{array}$ & $\begin{array}{l}\text { Drives change in ecosystem structure and function (1) by inducing } \\
\text { selective establishment episodes (or less commonly, selective } \\
\text { mortality) of vegetative functional groups - resulting in persistent } \\
\text { dominance shifts; and (2) due to extreme erosive forces for } \\
\text { detachment, entrainment, and redistribution and export of soil and } \\
\text { soil resources, potentially inducing geomorphic change. }\end{array}$ & $\begin{array}{l}\text { Seasonality, intensity, duration, frequency, timing in } \\
\text { relation to drought, and the amount of time required for } \\
\text { biotic and biotically structured ecosystem components } \\
\text { and functions to recover from drought. }\end{array}$ \\
\hline & & Wind storms & $\begin{array}{l}\text { Drives change in ecosystem structure and function due to extreme } \\
\text { erosive forces for detachment, entrainment, and redistribution and } \\
\text { export of soil and soil resources. }\end{array}$ & $\begin{array}{l}\text { Seasonality, intensity, duration, frequency, timing in } \\
\text { relation to drought, and the amount of time required for } \\
\text { biotic and biotically structured ecosystem components } \\
\text { and functions to recover from drought. }\end{array}$ \\
\hline & & $\begin{array}{l}\text { Extreme temperature } \\
\text { events }\end{array}$ & $\begin{array}{l}\text { Drives change in ecosystem structure and function by inducing } \\
\text { selective mortality, potentially resulting in long-term shifts in } \\
\text { dominants. }\end{array}$ & $\begin{array}{l}\text { Intensity, duration, frequency, extent, timing in relation } \\
\text { to other disturbances. }\end{array}$ \\
\hline
\end{tabular}




\begin{tabular}{|c|c|c|c|}
\hline $\begin{array}{l}\text { INTERACTIVE } \\
\text { CONTROLS* }^{*}\end{array}$ & COMPONENTS/PROCESSES & PRIMARY ECOSYSTEM FUNCTIONS & ATTRIBUTES/MEASURES \\
\hline \multirow{5}{*}{$\begin{array}{l}\text { Disturbance } \\
\text { regime } \\
\text { (continued) }\end{array}$} & Fire & $\begin{array}{l}\text { Drives change in ecosystem structure and function by (1) directly } \\
\text { altering vegetation structure (differential resistance and resilience to } \\
\text { fire), including spatial heterogeneity; ( } 2 \text { ) altering the forms, } \\
\text { bioavailability, and spatiotemporal distribution of soil resources; and ( } 3 \text { ) } \\
\text { increasing runoff and soil erosion. Over longer time scales, fire may } \\
\text { decrease erosion and runoff due to increases in herbaceous ground } \\
\text { cover. }\end{array}$ & $\begin{array}{l}\text { Intensity, spatial extent and pattern, frequency, timing } \\
\text { in relation to other disturbances such as extreme } \\
\text { precipitation and wind events. }\end{array}$ \\
\hline & Insect/disease outbreaks & $\begin{array}{l}\text { Drives change in ecosystem structure and function by inducing selective } \\
\text { and often widespread mortality, potentially resulting in long-term shifts } \\
\text { among dominant functional groups. May reduce ecosystem } \\
\text { resistance/resilience to other disturbances such as fire. }\end{array}$ & $\begin{array}{l}\text { Intensity, duration, frequency, extent, timing in relation } \\
\text { to other disturbances. }\end{array}$ \\
\hline & Herbivory & $\begin{array}{l}\text { Drives change in ecosystem structure and function by (1) altering } \\
\text { competitive relations among palatable and unpalatable plant taxa; (2) } \\
\text { altering vegetation resistance and resilience to drought, other } \\
\text { disturbances, and stressors; and (3) potentially affecting primary } \\
\text { productivity and litter deposition. In combination, these can alter } \\
\text { functional group structure, including spatial heterogeneity, and } \\
\text { ecosystem capacity to capture and retain soil resources. Excretion } \\
\text { further alters the spatiotemporal distribution of resources. }\end{array}$ & $\begin{array}{l}\text { Intensity, selectivity, spatial extent and pattern, } \\
\text { frequency, timing in relation to other disturbances such } \\
\text { as drought, and the amount of time required for biotic } \\
\text { and biotically structured ecosystem components and } \\
\text { functions to recover from drought. }\end{array}$ \\
\hline & Digging/burrowing & $\begin{array}{l}\text { Alters soil structure and function (creation of macropores potentially } \\
\text { increases water capture and retention); alters spatiotemporal distribution } \\
\text { of soil resources; generates patch structure/heterogeneity; potentially } \\
\text { alters structure of vegetative functional groups due to resource alteration } \\
\text { and creation of establishment opportunities. }\end{array}$ & $\begin{array}{l}\text { Spatial distribution and extent, frequency, depth, } \\
\text { timing in relation to other disturbances such as } \\
\text { extreme wind and precipitation events. }\end{array}$ \\
\hline & Trampling & $\begin{array}{l}\text { Destabilizes soil and decreases resistance of soil to erosion and } \\
\text { redistribution by wind and water; compacts soil (alters soil structure and } \\
\text { function); alters structure and function of biological soil crusts; alters } \\
\text { vegetation structure directly due to trampling of vegetation and indirectly } \\
\text { due to effects on soil characteristics. }\end{array}$ & $\begin{array}{l}\text { Intensity, spatial extent and pattern, frequency, timing } \\
\text { in relation to other disturbances such as extreme wind } \\
\text { and precipitation events, drought, and the amount of } \\
\text { time required for biotic and biotically structured } \\
\text { ecosystem components and functions to recover from } \\
\text { drought. }\end{array}$ \\
\hline \multirow{3}{*}{$\begin{array}{l}\text { Biotic } \\
\text { functional } \\
\text { groups }\end{array}$} & Predators & $\begin{array}{l}\text { Regulation of (or response to) prey populations, including granivores } \\
\text { and herbivores. May also impact ecosystem structure and function by } \\
\text { digging/burrowing (see above). }\end{array}$ & $\begin{array}{l}\text { Composition, quantity, population structure, and } \\
\text { dynamics; physiological condition. }\end{array}$ \\
\hline & Herbivores & $\begin{array}{l}\text { See Herbivory, above. May also impact ecosystem structure and } \\
\text { function by digging/burrowing (see above). [Potential agents of } \\
\text { disturbance - see herbivory, above.] }\end{array}$ & $\begin{array}{l}\text { Composition, quantity, population structure, and } \\
\text { dynamics; physiological condition. }\end{array}$ \\
\hline & Granivores & $\begin{array}{l}\text { Alteration of vegetation structure (composition and spatial } \\
\text { heterogeneity) due to selective collection, consumption, burial, and } \\
\text { redistribution of propagules. May also impact ecosystem structure and } \\
\text { function by digging/burrowing (see above). }\end{array}$ & $\begin{array}{l}\text { Composition, quantity, population structure, and } \\
\text { dynamics; physiological condition. }\end{array}$ \\
\hline
\end{tabular}




\begin{tabular}{|c|c|c|c|c|}
\hline $\begin{array}{l}\text { INTERACTIVE } \\
\text { CONTROLS* }\end{array}$ & \multicolumn{2}{|c|}{ COMPONENTS/PROCESSES } & PRIMARY ECOSYSTEM FUNCTIONS & ATTRIBUTES/MEASURES \\
\hline \multirow{5}{*}{$\begin{array}{l}\text { Biotic } \\
\text { functional } \\
\text { groups } \\
\text { (continued) }\end{array}$} & \multicolumn{2}{|c|}{$\begin{array}{l}\text { VEGETATION: } \\
\text { Small trees } \\
\text { Shrubs } \\
\text { Dwarf shrubs } \\
\text { Perennial grasses }\end{array}$} & $\begin{array}{l}\text { Energy capture and conversion; biomass production; litter deposition } \\
\text { (soil protection and inputs to nutrient cycles); nutrient retention } \\
\text { (intraplant cycling); environmental modification (reducing soil } \\
\text { temperatures and evaporative rates via shading and litter deposition; } \\
\text { generating resource heterogeneity via uptake, litter deposition, and } \\
\text { capture of waterborne and windborne materials); obstruction to wind } \\
\text { and overland water flow (reducing erosive energy and enhancing } \\
\text { capture and retention of soil resources); rainfall interception and } \\
\text { redistribution via stemflow (reducing erosive energy and enhancing } \\
\text { capture and retention of soil resources). In combination, these } \\
\text { functions contribute to resistance/resilience of soil functions to } \\
\text { disturbance by trampling and erosive forces of wind and water. } \\
\text { Provide fuel for fire and habitat structure for vertebrates and } \\
\text { invertebrates. }\end{array}$ & $\begin{array}{l}\text { Composition, quantity (cover and biomass), population } \\
\text { structure and dynamics, vertical structure, spatial } \\
\text { distribution/heterogeneity, photosynthetic pathway, leaf } \\
\text { longevity, litter quantity and quality (for example, C:N ratio), } \\
\text { flammability, productivity, physiological activity and } \\
\text { condition, resistance/resilience of structure and function to } \\
\text { dominant natural disturbances and anthropogenic stressors. }\end{array}$ \\
\hline & \multirow{5}{*}{ 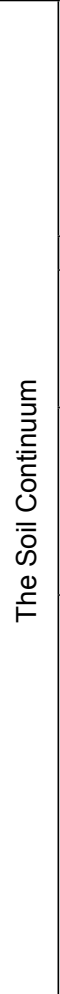 } & $\begin{array}{l}\text { Biological soil crusts } \\
\text { (photoautotrophs) }\end{array}$ & $\begin{array}{l}\text { Soil stabilization and soil-surface protection; energy capture and } \\
\text { conversion; nutrient capture, retention, and cycling ( } \mathrm{N} \text { fixation, capture } \\
\text { of airborne minerals in dust); obstruction to overland water flow } \\
\text { (increased surface roughness enhances capture and retention of soil } \\
\text { resources); environmental modification (albedo and soil temperature); } \\
\text { soil-temperature increases (decreased albedo); habitat creation (due } \\
\text { to long-term soil stabilization). }\end{array}$ & $\begin{array}{l}\text { Composition, quantity (cover and biomass), spatial } \\
\text { distribution and contiguity, microtopographic } \\
\text { heterogeneity/surface roughness, physiological activity and } \\
\text { condition, productivity, resistance/resilience of structure and } \\
\text { function to dominant natural disturbances and anthropogenic } \\
\text { stressors. }\end{array}$ \\
\hline & & & The Soil Surface & \\
\hline & & Roots & $\begin{array}{l}\text { Soil stabilization; nutrient and water acquisition and transport; water } \\
\text { redistribution in soil profile; organic-matter inputs (exudates and } \\
\text { tissues); macropore creation; rhizospere acidification (release } \mathrm{CO}_{2} \\
\text { and organic acids). }\end{array}$ & $\begin{array}{l}\text { Morphology, density, horizontal and vertical distribution, } \\
\text { spatial and temporal patterns of physiological activity, } \\
\text { productivity. }\end{array}$ \\
\hline & & Soil biota (heterotrophs) & $\begin{array}{l}\text { Litter decomposition and nutrient cycling; } \mathrm{N} \text { fixation; symbiotic } \\
\text { relations with vascular plants (symbiotic enhancement of nutrient and } \\
\text { water delivery to vascular plants may increase resistance/resilience of } \\
\text { these plants to drought or other disturbances). }\end{array}$ & $\begin{array}{l}\text { Composition, quantity (biomass), spatial distribution } \\
\text { vertically and horizontally, temporal distribution, spatial and } \\
\text { temporal patterns of physiological activity, productivity, } \\
\text { resistance/resilience of structure and function to dominant } \\
\text { natural disturbances and anthropogenic stressors. }\end{array}$ \\
\hline \multirow[t]{2}{*}{ Soil resources } & & $\begin{array}{l}\text { Soil mineral matrix } \\
\text { Soil organic matter } \\
\text { Soil water } \\
\text { Soil air }\end{array}$ & $\begin{array}{l}\text { Nutrient storage, supply, and cycling; water storage and supply; } \\
\text { medium for plant growth; habitat for soil biota involved in nutrient } \\
\text { cycling; positive effects on resistance/resilience of vegetative } \\
\text { functional groups to drought, herbivory, and trampling. }\end{array}$ & $\begin{array}{l}\text { Inherent properties (relatively insensitive to change): } \\
\text { Mineralogy and texture by depth, spatial heterogeneity in } \\
\text { these properties, depth. } \\
\text { Dynamic properties (subject to change): Aggregate stability } \\
\text { and bulk density (structure), organic-matter quantity and } \\
\text { quality (for example, C:N ratio), depth (often considered an } \\
\text { inherent property, but subject to change over decadal time } \\
\text { scales), erosion rate, infiltration rate, biotic activity, surface } \\
\text { crusting (biotic or physicochemical), surface roughness, } \\
\text { spatial heterogeneity of these properties, } \\
\text { resistance/resilience of structure and function to dominant } \\
\text { natural disturbances and anthropogenic stressors. }\end{array}$ \\
\hline & \multicolumn{2}{|c|}{ Soil temperature } & $\begin{array}{l}\text { Regulates physiological activity of autotrophic and heterotrophic soil } \\
\text { biota, including roots. }\end{array}$ & $\begin{array}{l}\text { Maximum, minimum, and average values by season, } \\
\text { temporal variability (seasonal and diurnal), spatial variability } \\
\text { (horizontally and vertically). }\end{array}$ \\
\hline
\end{tabular}

Primary sources: Whitford (2002), Herrick and others (2002), Belnap and Lange (2003), Ehleringer and others (2000), Seybold and others (1999), Whisenant (1999), and Ludwig and others (1997),

"Interactive controls are constrained by the five state factors-(1) global/regional atmospheric resources and conditions, (2) topography, (3) parent material, (4) potential biota, and (5) time (Jenny, 1980; Chapin and others, 1996). 
Appendix Table B. Potential effects of major anthropogenic stressors on structure and functioning of dryland ecosystems. Potential impacts of changing temperatures, atmospheric chemistry, and atmospheric circulation patterns (including precipitation) are excluded.

\begin{tabular}{|c|c|c|}
\hline Stressors & Stress mechanisms & $\begin{array}{l}\text { Potential effects on ecosystem components and functions (emphasizing effects on energy flow, nutrient capture and retention, } \\
\text { and water capture and retention) }\end{array}$ \\
\hline \multirow[t]{2}{*}{$\begin{array}{l}\text { Park use by } \\
\text { terrestrial } \\
\text { recreationists }\end{array}$} & $\begin{array}{l}\text { Trampling of soil and } \\
\text { vegetation }\end{array}$ & $\begin{array}{l}\text { Damaged biological soil crusts and vascular plants; decreased } \mathrm{N} \text { fixation by biological crusts; decreased soil-surface roughness; enhanced } \\
\text { recruitment opportunities for exotic plants favored by soil destabilization; altered vegetation structure; decreased soil protection by biological } \\
\text { crusts; decreased soil aggregate stability; decreased soil stability; decreased resistance of soil to erosion by wind and water; increased bulk } \\
\text { density; decreased infiltration; increased overland flow of water; decreased soil-water availability for plant growth, soil biotic activity, and nutrient } \\
\text { cycling; decreased root growth and soil-organic-matter inputs; decreased plant growth; decreased resistance and resilience of plants to drought; } \\
\text { increased redistribution and export of soil, litter, nutrients, and water; decreased capacity of ecosystem to capture and retain soil resources; } \\
\text { multiple cascading effects due to feedbacks among soil functions, soil-resource retention, resource heterogeneity, and vegetation structure. }\end{array}$ \\
\hline & $\begin{array}{l}\text { Introduction of invasive } \\
\text { exotic plants }\end{array}$ & See exotics, below. \\
\hline \multirow{4}{*}{$\begin{array}{l}\text { Livestock \& other } \\
\text { large herbivores }\end{array}$} & $\begin{array}{l}\text { Trampling of soil and } \\
\text { vegetation }\end{array}$ & See trampling, above. \\
\hline & Excessive herbivory & $\begin{array}{l}\text { Altered competitive relations of plants; reduced plant canopy cover; reduced fine fuels and frequency of low-intensity surface fires; altered } \\
\text { vegetation structure (for example, dominance shift from palatable plants to unpalatable plants or from herbaceous plants favored by fire to woody } \\
\text { plants eliminated by fire); reduced plant-canopy protection of soil; reduced vegetative obstruction of wind and overland water flow; reduced } \\
\text { capture and retention of soil resources; reduced litter deposition and litter-protection of soil; reduced soil-organic-matter inputs; reduced soil } \\
\text { aggregate stability; decreased resistance and resilience of soil to trampling; decreased root growth; decreased resistance and resilience of grazed } \\
\text { plants to drought; multiple cascading effects due to feedbacks among vegetation structure, soil-resource retention, resource heterogeneity, and } \\
\text { soil functions. }\end{array}$ \\
\hline & Excretion & $\begin{array}{l}\text { Nutrient losses ( } \mathrm{N} \text { volatilization); nutrient immobilization in dung pats; increased spatial and temporal heterogeneity of nutrients; eventual } \\
\text { alteration of vegetation structure; facilitation of exotic-plant invasion where nutrients are locally enriched (see exotics, below). }\end{array}$ \\
\hline & $\begin{array}{l}\text { Introduction of invasive } \\
\text { exotic plants }\end{array}$ & See exotics, below. \\
\hline Fire suppression & Altered fire regime & $\begin{array}{l}\text { Decreased frequency and extent of fire; altered vegetation composition/structure (for example, dominance shift from herbaceous plants favored } \\
\text { by fire to woody plants eliminated by fire); increased accumulation of coarse woody fuels; increased likelihood of high-intensity canopy fire; } \\
\text { decreased ecosystem resistance/resilience to impacts from drought and insect outbreaks. }\end{array}$ \\
\hline \multirow{3}{*}{$\begin{array}{l}\text { Invasive exotic } \\
\text { plants }\end{array}$} & $\begin{array}{l}\text { Competition with native } \\
\text { plants }\end{array}$ & Altered vegetation composition/structure; eventual alteration of soil-resource dynamics and/or heterogeneity due to vegetation-soil feedbacks. \\
\hline & $\begin{array}{l}\text { Altered soil-resource } \\
\text { dynamics }\end{array}$ & $\begin{array}{l}\text { Altered nutrient dynamics (for example, exotic characterized by different tissue chemistry and/or by different spatiotemporal patterns of nutrient } \\
\text { uptake and litter deposition than native plants); altered soil-water dynamics (for example, exotic characterized by different spatiotemporal patterns } \\
\text { of water use than native plants); eventual alteration of vegetation composition/structure due to soil-vegetation feedbacks. }\end{array}$ \\
\hline & Altered disturbance regime & $\begin{array}{l}\text { Increased frequency and extent of fire (facilitated by increased quantity, flammability, and/or spatial continuity of fuels); eventual alterations of } \\
\text { vegetation composition/structure and soil-resource availability due to strong feedbacks among fire, vegetation structure, and resource availability. }\end{array}$ \\
\hline \multirow{5}{*}{$\begin{array}{l}\text { Adjacent land } \\
\text { use activities }\end{array}$} & Trespass livestock & See livestock, above. \\
\hline & Introduction of exotic plants & See exotics, above. \\
\hline & $\begin{array}{l}\text { Accelerated transfers of } \\
\text { sediment, nutrients, and } \\
\text { water }\end{array}$ & $\begin{array}{l}\text { Soil-resource enrichment; eventual alteration of vegetation composition/structure; facilitation of exotic-plant invasion where resources are } \\
\text { enriched (see exotics, above); increased overland water flow (increased erosive energy of water); increased redistribution and export of soil and } \\
\text { nutrients. }\end{array}$ \\
\hline & Fire from adjacent lands & Increased susceptibility to high-intensity fire and associated ecosystem changes. \\
\hline & Altered landscape structure & Altered habitat structure, connectivity and habitat-use patterns of wildlife. \\
\hline \multirow{2}{*}{ Air pollutants } & Nitrogen deposition & $\begin{array}{l}\text { Soil-resource enrichment; potential alteration of vegetation composition and structure--including facilitation of exotic-plant invasion (see exotics, } \\
\text { above). }\end{array}$ \\
\hline & Ozone & Altered competitive relations between ozone-sensitive and ozone-tolerant plants; altered vegetation composition \& structure. \\
\hline
\end{tabular}


Appendix Table C. Climatic conditions, inherent ecosystem properties, and dynamic ecosystem properties hypothesized to confer resistance and resilience to selected ecosystem attributes in relation to particular disturbances or stressors. (BSC = biological soil crust; $--=$ not applicable)

\begin{tabular}{|c|c|c|c|c|c|c|c|}
\hline \multirow{2}{*}{$\begin{array}{l}\text { Disturbance or } \\
\text { stressor }\end{array}$} & \multirow{2}{*}{$\begin{array}{l}\text { Ecosystem } \\
\text { attribute }\end{array}$} & \multicolumn{2}{|c|}{ Climatic conditions } & \multicolumn{2}{|c|}{ Inherent ecosystem properties ${ }^{1}$} & \multicolumn{2}{|c|}{ Dynamic ecosystem properties ${ }^{2}$} \\
\hline & & Resistance & Resilience & Resistance & Resilience & Resistance & Resilience \\
\hline \multirow[t]{2}{*}{ Drought } & $\begin{array}{l}\text { Native grass } \\
\text { population } \\
\text { structure }\end{array}$ & \multirow{2}{*}{$\begin{array}{l}\text { Coincident } \\
\text { temperatures and } \\
\text { winds that do not } \\
\text { exacerbate } \\
\text { evaporational } \\
\text { demands }\end{array}$} & \multirow{2}{*}{$\begin{array}{l}\text { Antecedent moisture } \\
\& \text { temperature } \\
\text { conditions favorable } \\
\text { for seed production } \\
\text { by native plants } \\
\text { Subsequent moisture } \\
\& \text { temperature } \\
\text { conditions favorable } \\
\text { for plant growth \& } \\
\text { soil biotic activity; } \\
\text { precipitation } \\
\text { characterized by } \\
\text { timing, intensity, and } \\
\text { event size that } \\
\text { maximize likelihood } \\
\text { of infiltration and soil- } \\
\text { water recharge }\end{array}$} & \multicolumn{2}{|c|}{$\begin{array}{l}\text { Deep sandy soil; run-on landscape } \\
\text { position }\end{array}$} & $\begin{array}{l}\text { Soil and vegetation } \\
\text { structure that enhance site } \\
\text { capacity to capture, retain, } \\
\text { and cycle water and mineral } \\
\text { nutrients; physiological } \\
\text { condition of native grass } \\
\text { populations unimpacted by } \\
\text { other disturbances or } \\
\text { stressors (for example, } \\
\text { excessive herbivory) }\end{array}$ & \multirow{2}{*}{$\begin{array}{l}\text { Seed/propagule } \\
\text { banks; soil and } \\
\text { vegetation structure } \\
\text { that enhance site } \\
\text { capacity to capture, } \\
\text { retain and cycle water } \\
\text { and mineral nutrients; } \\
\text { physiological condition } \\
\text { of native plant } \\
\text { populations } \\
\text { unimpacted by other } \\
\text { disturbances or } \\
\text { stressors; absence of } \\
\text { invasive exotic } \\
\text { species capable of } \\
\text { rapid population } \\
\text { expansion and } \\
\text { exclusion of native } \\
\text { plant populations }\end{array}$} \\
\hline & $\begin{array}{l}\text { Shrub/tree } \\
\text { population } \\
\text { structure }\end{array}$ & & & \multicolumn{2}{|c|}{$\begin{array}{l}\text { Rocky soil (including rock outcrops with } \\
\text { joints and fractures); run-on landscape } \\
\text { position }\end{array}$} & $\begin{array}{l}\text { Natural stand structure (that } \\
\text { is, not overstocked); soil } \\
\text { and vegetation structure } \\
\text { that enhance site capacity } \\
\text { to capture, retain, and cycle } \\
\text { water and mineral nutrients; } \\
\text { physiological condition of } \\
\text { native shrub-tree } \\
\text { populations unimpacted by } \\
\text { other disturbances or } \\
\text { stressors }\end{array}$ & \\
\hline $\begin{array}{l}\text { Insect outbreak } \\
\text { (Here assumed to be } \\
\text { triggered by drought } \\
\text { stress) }\end{array}$ & $\begin{array}{l}\text { Tree } \\
\text { population } \\
\text { structure }\end{array}$ & $\begin{array}{l}\text { Antecedent and } \\
\text { coincident moisture } \\
\text { \& temperature } \\
\text { conditions } \\
\text { favorable for tree } \\
\text { growth }\end{array}$ & $\begin{array}{l}\text { Antecedent moisture } \\
\& \text { temperature } \\
\text { conditions favorable } \\
\text { for seed production } \\
\text { by native plants } \\
\text { Subsequent moisture } \\
\text { \& temperature } \\
\text { conditions favorable } \\
\text { for tree growth }\end{array}$ & \multicolumn{2}{|c|}{$\begin{array}{l}\text { Rocky soil (including rock outcrops with } \\
\text { joints and fractures); run-on landscape } \\
\text { position }\end{array}$} & $\begin{array}{l}\text { Natural stand structure (that } \\
\text { is, not overstocked); soil } \\
\text { and vegetation structure } \\
\text { that enhance site capacity } \\
\text { to capture, retain, and cycle } \\
\text { water and mineral nutrients; } \\
\text { physiological condition of } \\
\text { native shrub-tree } \\
\text { populations unimpacted by } \\
\text { other disturbances or } \\
\text { stressors }\end{array}$ & $\begin{array}{l}\text { Seed/propagule } \\
\text { banks; soil and } \\
\text { vegetation structure } \\
\text { that enhance site } \\
\text { capacity to capture, } \\
\text { retain, and cycle water } \\
\text { and mineral nutrients; } \\
\text { physiological condition } \\
\text { of native plant } \\
\text { populations } \\
\text { unimpacted by other } \\
\text { disturbances or } \\
\text { stressors; absence of } \\
\text { invasive exotic } \\
\text { species capable of } \\
\text { rapid population } \\
\text { expansion and } \\
\text { exclusion of native } \\
\text { plant populations }\end{array}$ \\
\hline
\end{tabular}

${ }^{1}$ Inherent ecosystem properties are relatively insensitive to change in relation to land use, management, and climate (for example, soil texture, mineralogy, horizonation, and depth; landscape/topographic position).

${ }^{2}$ Dynamic ecosystem properties are sensitive to change in relation to land use, management, and climate (for example, soil structure, biotic activity, and vegetation composition and structure). Dynamic properties are generally mediated by biotic processes. 


\begin{tabular}{|c|c|c|c|c|c|c|c|}
\hline \multirow{2}{*}{$\begin{array}{l}\text { Disturbance or } \\
\text { stressor }\end{array}$} & \multirow{2}{*}{$\begin{array}{l}\text { Ecosystem } \\
\text { attribute }\end{array}$} & \multicolumn{2}{|c|}{ Climatic conditions } & \multicolumn{2}{|c|}{ Inherent ecosystem properties } & \multicolumn{2}{|c|}{ Dynamic ecosystem properties } \\
\hline & & Resistance & Resilience & Resistance & Resilience & Resistance & Resilience \\
\hline $\begin{array}{l}\text { Surface fire } \\
\text { (As natural } \\
\text { disturbance) }\end{array}$ & $\begin{array}{l}\text { Native } \\
\text { vegetation } \\
\text { composition } \\
\text { \& structure }\end{array}$ & $\begin{array}{l}\text { Antecedent moisture } \\
\& \text { temperature } \\
\text { conditions that } \\
\text { diminish fuel } \\
\text { production and/or } \\
\text { diminish fuel } \\
\text { flammability; calm } \\
\text { wind conditions }\end{array}$ & $\begin{array}{l}\text { Subsequent moisture } \\
\& \text { temperature } \\
\text { conditions favorable } \\
\text { for plant growth \& soil } \\
\text { biotic activity }\end{array}$ & $\begin{array}{l}\text { Natural landscape } \\
\text { fragmentation (that is, } \\
\text { sites potentially } \\
\text { capable of supporting } \\
\text { surface fire are } \\
\text { discontinuously } \\
\text { distributed in the } \\
\text { landscape, separated } \\
\text { by natural fuel } \\
\text { breaks) }\end{array}$ & -- & $\begin{array}{l}\text { Abundance and } \\
\text { spatial continuity of } \\
\text { fine surface fuels } \\
\text { inadequate to carry } \\
\text { fire }\end{array}$ & $\begin{array}{l}\text { Seed/propagule } \\
\text { banks; soil and } \\
\text { vegetation structure } \\
\text { that enhance site } \\
\text { capacity to capture, } \\
\text { retain, and cycle water } \\
\text { and mineral nutrients; } \\
\text { physiological condition } \\
\text { of native plant } \\
\text { populations } \\
\text { unimpacted by other } \\
\text { disturbances or } \\
\text { stressors; absence of } \\
\text { invasive exotic } \\
\text { species capable of } \\
\text { rapid population } \\
\text { expansion and } \\
\text { exclusion of native } \\
\text { plant populations } \\
\text { through competition or } \\
\text { alteration of fire } \\
\text { regimes }\end{array}$ \\
\hline $\begin{array}{l}\text { Stand-replacing } \\
\text { canopy fire } \\
\text { (As natural } \\
\text { disturbance) }\end{array}$ & $\begin{array}{l}\text { Native } \\
\text { vegetation } \\
\text { composition } \\
\text { \& structure }\end{array}$ & $\begin{array}{l}\text { Antecedent moisture } \\
\& \text { temperature } \\
\text { conditions that } \\
\text { diminish fuel } \\
\text { production and/or } \\
\text { diminish fuel } \\
\text { flammability; calm } \\
\text { wind conditions }\end{array}$ & $\begin{array}{l}\text { Antecedent moisture } \\
\& \text { temperature } \\
\text { conditions favorable } \\
\text { for seed production } \\
\text { by native plants } \\
\text { Subsequent moisture } \\
\& \text { temperature } \\
\text { conditions favorable } \\
\text { for vegetative } \\
\text { reproduction (for } \\
\text { sprouters), plant } \\
\text { establishment, plant } \\
\text { growth, \& soil biotic } \\
\text { activity }\end{array}$ & $\begin{array}{l}\text { Natural landscape } \\
\text { fragmentation (that is, } \\
\text { sites potentially } \\
\text { capable of supporting } \\
\text { high-intensity stand- } \\
\text { replacing fire are } \\
\text { discontinuously } \\
\text { distributed in the } \\
\text { landscape, separated } \\
\text { by natural fuel } \\
\text { breaks) }\end{array}$ & -- & $\begin{array}{l}\text { Abundance and } \\
\text { spatial continuity of } \\
\text { ladder and canopy } \\
\text { fuels inadequate to } \\
\text { carry fire }\end{array}$ & $\begin{array}{l}\text { Seed/propagule } \\
\text { banks; soil and } \\
\text { vegetation structure } \\
\text { that enhance site } \\
\text { capacity to capture, } \\
\text { retain, and cycle water } \\
\text { and mineral nutrients; } \\
\text { physiological condition } \\
\text { of native plant } \\
\text { populations } \\
\text { unimpacted by other } \\
\text { disturbances or } \\
\text { stressors; absence of } \\
\text { invasive exotic } \\
\text { species capable of } \\
\text { rapid population } \\
\text { expansion and } \\
\text { exclusion of native } \\
\text { plant populations } \\
\text { through competition or } \\
\text { alteration of fire } \\
\text { regimes }\end{array}$ \\
\hline
\end{tabular}




\begin{tabular}{|c|c|c|c|c|c|c|c|}
\hline \multirow{2}{*}{$\begin{array}{l}\text { Disturbance } \\
\text { or stressor }\end{array}$} & \multirow{2}{*}{$\begin{array}{l}\text { Ecosystem } \\
\text { attribute }\end{array}$} & \multicolumn{2}{|c|}{ Climatic conditions } & \multicolumn{2}{|c|}{ Inherent ecosystem properties } & \multicolumn{2}{|c|}{ Dynamic ecosystem properties } \\
\hline & & Resistance & Resilience & Resistance & Resilience & Resistance & Resilience \\
\hline $\begin{array}{l}\text { Erosive wind } \\
\text { events }\end{array}$ & $\begin{array}{l}\text { Soil } \\
\text { retention } \\
\\
\text { (Includes fine } \\
\text { soil particles, } \\
\text { litter, organic } \\
\text { matter, } \\
\text { nutrients) }\end{array}$ & $\begin{array}{l}\text { Antecedent and } \\
\text { coincident moisture \& } \\
\text { temperature } \\
\text { conditions favorable } \\
\text { for plant growth, BSC } \\
\text { growth, soil biotic } \\
\text { activity, maintenance } \\
\text { of moist soil } \\
\text { conditions, formation } \\
\text { of stable soil } \\
\text { aggregates, and/or } \\
\text { formation of physical } \\
\text { crust }\end{array}$ & $\begin{array}{l}\text { Antecedent moisture \& } \\
\text { temperature conditions } \\
\text { favorable for seed } \\
\text { production by native } \\
\text { plants } \\
\text { Subsequent moisture \& } \\
\text { temperature conditions } \\
\text { favorable for plant } \\
\text { growth, BSC growth, soil } \\
\text { biotic activity, } \\
\text { maintenance of moist } \\
\text { soil conditions, formation } \\
\text { of stable soil } \\
\text { aggregates, and/or } \\
\text { formation of physical } \\
\text { crust }\end{array}$ & \multicolumn{2}{|c|}{$\begin{array}{l}\text { Landscape setting that provides protection } \\
\text { from erosive winds due to aspect, } \\
\text { absence of wind-funneling landforms, } \\
\text { minimal fetch exposure, etc.; soils with low } \\
\text { erodibility by wind (for example, fine- } \\
\text { textured soil not exposed to bombardment } \\
\text { from saltating sand particles; soil surface } \\
\text { covered by rock fragments) } \\
\text { Soil physical and chemical properties and } \\
\text { landscape setting (for example, north- } \\
\text { facing aspect) that favor plant growth, } \\
\text { BSC growth, soil biotic activity, and/or } \\
\text { reformation of physical crust }\end{array}$} & $\begin{array}{l}\text { Soil aggregate stability and } \\
\text { ground cover of BSCs, } \\
\text { stable litter, and/or other } \\
\text { soil-stabilizing features at } \\
\text { maximum levels relative to } \\
\text { potential (that is, } \\
\text { undiminished by other } \\
\text { disturbances or stressors); } \\
\text { vegetation structure that } \\
\text { obstructs wind and } \\
\text { reduces near-surface wind } \\
\text { velocity (for example, tall, } \\
\text { closely spaced vegetation) }\end{array}$ & $\begin{array}{l}\text { Seed/propagule } \\
\text { banks; } \\
\text { unconstrained BSC } \\
\text { growth, plant growth, } \\
\text { litter accumulation, } \\
\text { soil biotic activity, } \\
\text { and soil aggregation; } \\
\text { soil and vegetation } \\
\text { structure that } \\
\text { enhance site } \\
\text { capacity to capture, } \\
\text { retain, and cycle } \\
\text { water and mineral } \\
\text { nutrients }\end{array}$ \\
\hline $\begin{array}{l}\text { Erosive } \\
\text { precipitation/ } \\
\text { flood events }\end{array}$ & $\begin{array}{l}\text { Soil \& water } \\
\text { retention } \\
\\
\text { (Includes fine } \\
\text { soil particles, } \\
\text { litter, organic } \\
\text { manter, } \\
\text { nutrients) }\end{array}$ & $\begin{array}{l}\text { Antecedent moisture } \\
\& \text { temperature } \\
\text { conditions favorable } \\
\text { for plant growth, BSC } \\
\text { growth, soil biotic } \\
\text { activity, and formation } \\
\text { of stable soil } \\
\text { aggregates }\end{array}$ & $\begin{array}{l}\text { Antecedent moisture \& } \\
\text { temperature conditions } \\
\text { favorable for seed } \\
\text { production by native } \\
\text { plants } \\
\text { Subsequent moisture \& } \\
\text { temperature conditions } \\
\text { favorable for plant } \\
\text { growth, BSC growth, soil } \\
\text { biotic activity, and } \\
\text { formation of stable soil } \\
\text { aggregates }\end{array}$ & $\begin{array}{l}\text { Deep sandy soil ( } \\
\text { storage capacity); } \\
\text { rock fragments; lo } \\
\text { slope length; land } \\
\text { not receive runoff } \\
\text { Soil physical and } \\
\text { landscape setting } \\
\text { facing aspect) tha } \\
\text { BSC growth, and }\end{array}$ & $\begin{array}{l}\text { ration and } \\
\text { ace covered by } \\
\text { gradient; short } \\
\text { sition that does } \\
\text { lope positions } \\
\text { properties and } \\
\text { nple, north- } \\
\text { ant growth, } \\
\text { activity }\end{array}$ & $\begin{array}{l}\text { Soil aggregate stability and } \\
\text { ground cover of BSCs, } \\
\text { stable litter, and/or other } \\
\text { soil-stabilizing features at } \\
\text { maximum level relative to } \\
\text { potential (that is, } \\
\text { undiminished by other } \\
\text { disturbances or stressors); } \\
\text { vegetation structure that } \\
\text { obstructs over-land water } \\
\text { flow, increases flow } \\
\text { tortuosity, and reduces } \\
\text { flow velocity }\end{array}$ & $\begin{array}{l}\text { Seed/propagule } \\
\text { banks; } \\
\text { unconstrained BSC } \\
\text { growth, plant growth, } \\
\text { litter accumulation, } \\
\text { soil biotic activity, } \\
\text { and soil aggregation; } \\
\text { soil and vegetation } \\
\text { structure that } \\
\text { enhance site } \\
\text { capacity to capture, } \\
\text { retain, and cycle } \\
\text { water and mineral } \\
\text { nutrients }\end{array}$ \\
\hline $\begin{array}{l}\text { Trampling \& } \\
\text { other soil- } \\
\text { surface } \\
\text { disturbances }\end{array}$ & $\begin{array}{l}\text { Soil stability } \\
\text { (Susceptibility } \\
\text { to wind erosion) }\end{array}$ & $\begin{array}{l}\text { Antecedent moisture } \\
\& \text { temperature } \\
\text { conditions favorable } \\
\text { for plant growth, BSC } \\
\text { growth, soil biotic } \\
\text { activity, and formation } \\
\text { of stable soil } \\
\text { aggregates } \\
\text { Coincident moisture \& } \\
\text { temperature } \\
\text { conditions favorable } \\
\text { for maintaining soils in } \\
\text { moist or frozen state } \\
\text { (frozen or dry in case } \\
\text { of clay soils) }\end{array}$ & $\begin{array}{l}\text { Antecedent moisture \& } \\
\text { temperature conditions } \\
\text { favorable for seed } \\
\text { production by native } \\
\text { plants } \\
\text { Subsequent moisture \& } \\
\text { temperature conditions } \\
\text { favorable for plant } \\
\text { growth, BSC growth, soil } \\
\text { biotic activity, formation } \\
\text { of stable soil } \\
\text { aggregates, and/or } \\
\text { formation of physical } \\
\text { crust }\end{array}$ & $\begin{array}{l}\text { Soil surface cover } \\
\text { fragments } \\
\text { Soil physical and } \\
\text { landscape setting } \\
\text { facing aspect) tha } \\
\text { BSC growth, soil } \\
\text { reformation of phy }\end{array}$ & $\begin{array}{l}\text { ck or rock } \\
\text { properties and } \\
\text { nple, north- } \\
\text { ant growth, } \\
\text { vity, or } \\
\text { st }\end{array}$ & $\begin{array}{l}\text { Maximum degree of soil } \\
\text { stabilization provided by } \\
\text { biotic features relatively } \\
\text { unimpacted by trampling or } \\
\text { other soil-surface } \\
\text { disturbances, such as } \\
\text { stable litter, continuous } \\
\text { herbaceous ground cover, } \\
\text { and continuous canopy } \\
\text { cover. Soil stability in } \\
\text { relation to wind erosion not } \\
\text { dependent on integrity of } \\
\text { sensitive biological or } \\
\text { physical crusts. }\end{array}$ & $\begin{array}{l}\text { Seed/propagule } \\
\text { banks; } \\
\text { unconstrained BSC } \\
\text { growth, plant growth, } \\
\text { litter accumulation, } \\
\text { soil biotic activity, } \\
\text { and soil aggregation; } \\
\text { soil and vegetation } \\
\text { structure that } \\
\text { enhance site } \\
\text { capacity to capture, } \\
\text { retain, and cycle } \\
\text { water and mineral } \\
\text { nutrients }\end{array}$ \\
\hline
\end{tabular}




\begin{tabular}{|c|c|c|c|c|c|c|c|}
\hline \multirow{2}{*}{$\begin{array}{l}\text { Disturbance } \\
\text { or stressor }\end{array}$} & \multirow{2}{*}{$\begin{array}{l}\text { Ecosystem } \\
\text { attribute }\end{array}$} & \multicolumn{2}{|c|}{ Climatic conditions } & \multicolumn{2}{|c|}{ Inherent ecosystem properties } & \multicolumn{2}{|c|}{ Dynamic ecosystem properties } \\
\hline & & Resistance & Resilience & Resistance & Resilience & Resistance & Resilience \\
\hline $\begin{array}{l}\text { Trampling \& } \\
\text { other soil- } \\
\text { surface } \\
\text { disturbances }\end{array}$ & $\begin{array}{l}\text { Soil stability } \\
\text { and } \\
\text { infiltration } \\
\text { capacity } \\
\text { (Susceptibility to } \\
\text { water erosion) }\end{array}$ & $\begin{array}{l}\text { Antecedent } \\
\text { moisture \& } \\
\text { temperature } \\
\text { conditions favorable } \\
\text { for plant growth, } \\
\text { BSC growth, soil } \\
\text { biotic activity, and } \\
\text { formation of stable } \\
\text { soil aggregates } \\
\text { Coincident } \\
\text { conditions: in } \\
\text { presence of BSCs, } \\
\text { moist or frozen } \\
\text { soils; in absence of } \\
\text { BSCs, frozen or dry } \\
\text { soils }\end{array}$ & $\begin{array}{l}\text { Antecedent moisture \& } \\
\text { temperature conditions } \\
\text { favorable for seed } \\
\text { production by native plants } \\
\text { Subsequent moisture \& } \\
\text { temperature conditions } \\
\text { favorable for plant growth, } \\
\text { BSC growth, soil biotic } \\
\text { activity, and formation of } \\
\text { stable soil aggregates } \\
\text { Occurrence of wet-dry or } \\
\text { freeze-thaw cycles } \\
\text { required to enhance } \\
\text { recovery of compacted } \\
\text { soils }\end{array}$ & \multicolumn{2}{|c|}{$\begin{array}{l}\text { Sandy soil or soil surface covered by } \\
\text { rock or rock fragments } \\
\text { Soil physical and chemical properties } \\
\text { and landscape setting (for example, } \\
\text { north-facing aspect) that favor plant } \\
\text { growth, BSC growth, and soil biotic } \\
\text { activity }\end{array}$} & $\begin{array}{l}\text { Maximum degree of soil } \\
\text { stabilization provided by } \\
\text { biotic features relatively } \\
\text { unimpacted by trampling or } \\
\text { other soil-surface } \\
\text { disturbances, such as } \\
\text { stable litter, continuous } \\
\text { herbaceous ground cover, } \\
\text { and continuous canopy } \\
\text { cover; site hydrologic } \\
\text { functioning and soil stability } \\
\text { in relation to water erosion } \\
\text { not dependent on integrity } \\
\text { of sensitive BSCs }\end{array}$ & $\begin{array}{l}\text { Seed/propagule banks; } \\
\text { unconstrained BSC } \\
\text { growth, plant growth, } \\
\text { litter accumulation, soil } \\
\text { biotic activity, and soil } \\
\text { aggregation; soil and } \\
\text { vegetation structure } \\
\text { that enhance site } \\
\text { capacity to capture, } \\
\text { retain, and cycle water } \\
\text { and mineral nutrients }\end{array}$ \\
\hline $\begin{array}{l}\text { Excessive } \\
\text { herbivory }\end{array}$ & $\begin{array}{l}\text { Native } \\
\text { vegetation } \\
\text { composition } \\
\& \text { structure }\end{array}$ & $\begin{array}{l}\text { Antecedent and } \\
\text { coincident moisture } \\
\& \text { temperature } \\
\text { conditions favorable } \\
\text { for plant growth and } \\
\text { soil biotic activity }\end{array}$ & $\begin{array}{l}\text { Antecedent moisture \& } \\
\text { temperature conditions } \\
\text { favorable for seed } \\
\text { production by preferred } \\
\text { forage species } \\
\text { Subsequent moisture \& } \\
\text { temperature conditions } \\
\text { favorable for soil biotic } \\
\text { activity and regrowth, seed } \\
\text { production, and } \\
\text { germination/establishment } \\
\text { of defoliated plants }\end{array}$ & $\begin{array}{l}\text { Soil physical and } \\
\text { chemical } \\
\text { properties and } \\
\text { landscape settings } \\
\text { that DO NOT favor } \\
\text { growth of plants } \\
\text { that are palatable } \\
\text { to predominant } \\
\text { large-bodied } \\
\text { herbivores } \\
\text { Soil physical } \\
\text { properties and } \\
\text { landscape settings } \\
\text { that DO NOT } \\
\text { facilitate access or } \\
\text { mobility of } \\
\text { predominant large- } \\
\text { bodied herbivores }\end{array}$ & $\begin{array}{l}\text { Soil physical and } \\
\text { chemical } \\
\text { properties and } \\
\text { landscape setting } \\
\text { (for example, rich } \\
\text { alluvial soils, } \\
\text { riparian corridors) } \\
\text { that favor } \\
\text { vigorous plant } \\
\text { growth and soil } \\
\text { biotic activity }\end{array}$ & $\begin{array}{l}\text { Plant communities with no } \\
\text { plant species palatable to } \\
\text { predominant large-bodied } \\
\text { herbivores } \\
\text { OR } \\
\text { Plant communities in which } \\
\text { all species are equally } \\
\text { preferred by predominant } \\
\text { large-bodied herbivores } \\
\text { and exhibit similar } \\
\text { physiological/morphological } \\
\text { responses to defoliation } \\
\text { (that is, preferential } \\
\text { herbivory does not favor } \\
\text { one species over another) }\end{array}$ & $\begin{array}{l}\text { Seed/propagule banks; } \\
\text { soil and vegetation } \\
\text { structure that enhance } \\
\text { site capacity to } \\
\text { capture, retain, and } \\
\text { cycle water and } \\
\text { mineral nutrients; } \\
\text { physiological condition } \\
\text { of defoliated plant } \\
\text { populations } \\
\text { unimpacted by other } \\
\text { disturbances or } \\
\text { stressors; absence of } \\
\text { unpalatable plants } \\
\text { (woody or herbaceous, } \\
\text { native or exotic) } \\
\text { capable of rapid } \\
\text { population expansion } \\
\text { and exclusion of } \\
\text { palatable native plant } \\
\text { populations through } \\
\text { competition or } \\
\text { alteration of fire } \\
\text { regimes }\end{array}$ \\
\hline $\begin{array}{l}\text { Invasive } \\
\text { exotic plants }\end{array}$ & $\begin{array}{l}\text { Native } \\
\text { vegetation } \\
\text { composition } \\
\text { \& structure }\end{array}$ & $\begin{array}{l}\text { Conditions that favor } \\
\text { relative to invaders ( } \\
\text { and invaders); in gen } \\
\text { resource availability }\end{array}$ & $\begin{array}{l}\text { native plant communities } \\
\text { ill vary among communities } \\
\text { ral, conditions that constrain }\end{array}$ & $\begin{array}{l}\text { Soil physical and } \\
\text { chemical } \\
\text { properties and } \\
\text { landscape settings } \\
\text { that present harsh } \\
\text { resource } \\
\text { constraints for } \\
\text { vascular plants }\end{array}$ & -- & $\begin{array}{l}\text { Growth, competitive ability, } \\
\text { and reproduction of native } \\
\text { plant populations } \\
\text { undiminished by other } \\
\text { disturbances or stressors; } \\
\text { soil-surface conditions that } \\
\text { restrict safe-site } \\
\text { opportunities for invasives }\end{array}$ & $\begin{array}{l}\text { Growth, competitive } \\
\text { ability, and } \\
\text { reproduction of native } \\
\text { plant populations } \\
\text { undiminished by other } \\
\text { disturbances or } \\
\text { stressors }\end{array}$ \\
\hline
\end{tabular}

